\title{
Metamorphic Conditions of Neotethyan Meliatic Accretionary Wedge Estimated by Thermodynamic Modelling and Geothermobarometry (Inner Western Carpathians)
}

\author{
Ondrej Nemec ${ }^{1}{ }^{1}$, Marián Putiš ${ }^{1, *}$, Peter Bačík ${ }^{1}$ [D, Peter Ružička ${ }^{1}$ and Zoltán Németh ${ }^{2}$ \\ 1 Department of Mineralogy and Petrology, Faculty of Natural Sciences, Comenius University in Bratislava, \\ SK-842 15 Bratislava, Slovakia; ondrej.nemec@uniba.sk(O.N.); peter.bacik@uniba.sk (P.B.); \\ peter.ruzicka@uniba.sk (P.R.) \\ 2 State Geological Institute of Dionýz Štúr, SK-817 04 Bratislava, Slovakia; zoltan.nemeth@geology.sk \\ * Correspondence: marian.putis@uniba.sk
}

Received: 6 October 2020; Accepted: 3 December 2020; Published: 6 December 2020

\begin{abstract}
Metamorphic evolution of an accretionary wedge can be constrained by a reconstructed P-T conditions of the oceanic and continental margin fragments. This paper deals with the metamorphic overprinting of the Inner Western Carpathians (IWC) Meliatic Triassic-Jurassic paleotectonic units after the closure of the Neotethyan Meliata Basin. Medium to high-pressure and lower temperature conditions were estimated by Perple_X pseudosection modelling, combined with garnet-phengite, calcite-dolomite and chlorite thermometers and chlorite-phengite and phengite barometers. The Late Jurassic subductional burial to a maximum $50 \mathrm{~km}$ depth was estimated from the Bôrka Unit continental margin fragments at $520^{\circ} \mathrm{C}$ and $1.55 \mathrm{GPa}$. This is compatible with the metamorphic peak garnet-glaucophane-phengite assemblage of blueschist facies in metabasites. The Jaklovce Unit oceanic fragments were subducted to maximum $35-40 \mathrm{~km}$ at $390-420{ }^{\circ} \mathrm{C}$ and $1.1-1.3 \mathrm{GPa}$. Metabasalts and metadolerites contain winchite, riebeckite, actinolite, chlorite, albite, epidote and phengite. A glaucophane-bearing metabasalt recorded an intra-oceanic subduction in blueschist-facies conditions. Rare amphibolite-facies metabasalts of this unit indicate the base of an inferred oceanic crust sliver obducted onto the continental margin wedge. The Meliata Unit oceanic/continental margin flysch calciclastic and siliciclastic metasediments suggest the burial to approximately $15-20 \mathrm{~km}$ at $250-350{ }^{\circ} \mathrm{C}$ and $0.4-0.6 \mathrm{GPa}$. This is indicated by a newly formed albite, K-feldspar, illite-phengite and chlorite associated with quartz and/or calcite and dolomite in these rocks. Magnesio-hastingsite to magnesio-hornblende bearing metagabbro with newly formed metamorphic magnesio-riebeckite and actinolite is an inferred detached Meliatic block tectonically emplaced in a Permian salinar mélange in the Silica Nappe hanging wall. Reconstructed P-T paths indicate variable metamorphic conditions from the medium-pressure to high-pressure subduction of the Bôrka and Jaklovce units to the Meliata Unit shallow burial in an accretionary wedge during Late Jurassic to Early Cretaceous Meliaticum evolution. Mélange blocks of Meliaticum incorporate different juxtaposed Meliatic paleotectonic units exposed in nappe outliers overlying the IWC Gemeric and Veporic superunits.
\end{abstract}

Keywords: MP-HP/LT metamorphism; thermodynamic modelling; geothermobarometry; Neotethyan Meliaticum; accretionary wedge; Inner Western Carpathians

\section{Introduction}

The subduction-related accretionary wedges [1] have variable metamorphic $\mathrm{P}-\mathrm{T}$ conditions of the oceanic and continental margin fragments [2-7]. Therefore, the high-pressure rocks in orogenic 
belts are reliable markers of paleosubduction zones. Reconstructed $\mathrm{P}-\mathrm{T}$ conditions provide useful information on the burial depths of the original paleotectonic units in an accretionary wedge.

The Meliatic Superunit, or Meliaticum, of the Inner Western Carpathians (IWC; Figure 1) originated in a NW Neotethys oceanic and continental margin [8-17] as an embayment separating the Eurasian and Gondwanian parts of Pangea [13,17-21]. Some authors reported that the Meliata Basin is a back-arc basin above a Paleotethys subduction zone [19,22-24]. The Meliaticum mélange blocks record a closure of the Neotethyan Middle Triassic to Late Jurassic Meliatic Basin due to the subduction of its oceanic and continental margin crust during the Late Jurassic [8,11-16]. Hence, the Meliaticum occurs in the form of exhumed kilometre-size blocks overlying the inferred Gemericum northern continental margin (Figure 2). This implies a breakdown of the Meliatic Late Jurassic-Early Cretaceous subduction-related accretionary wedge during the Cretaceous orogenic processes; a transformation model to an orogenic wedge was proposed by [15].

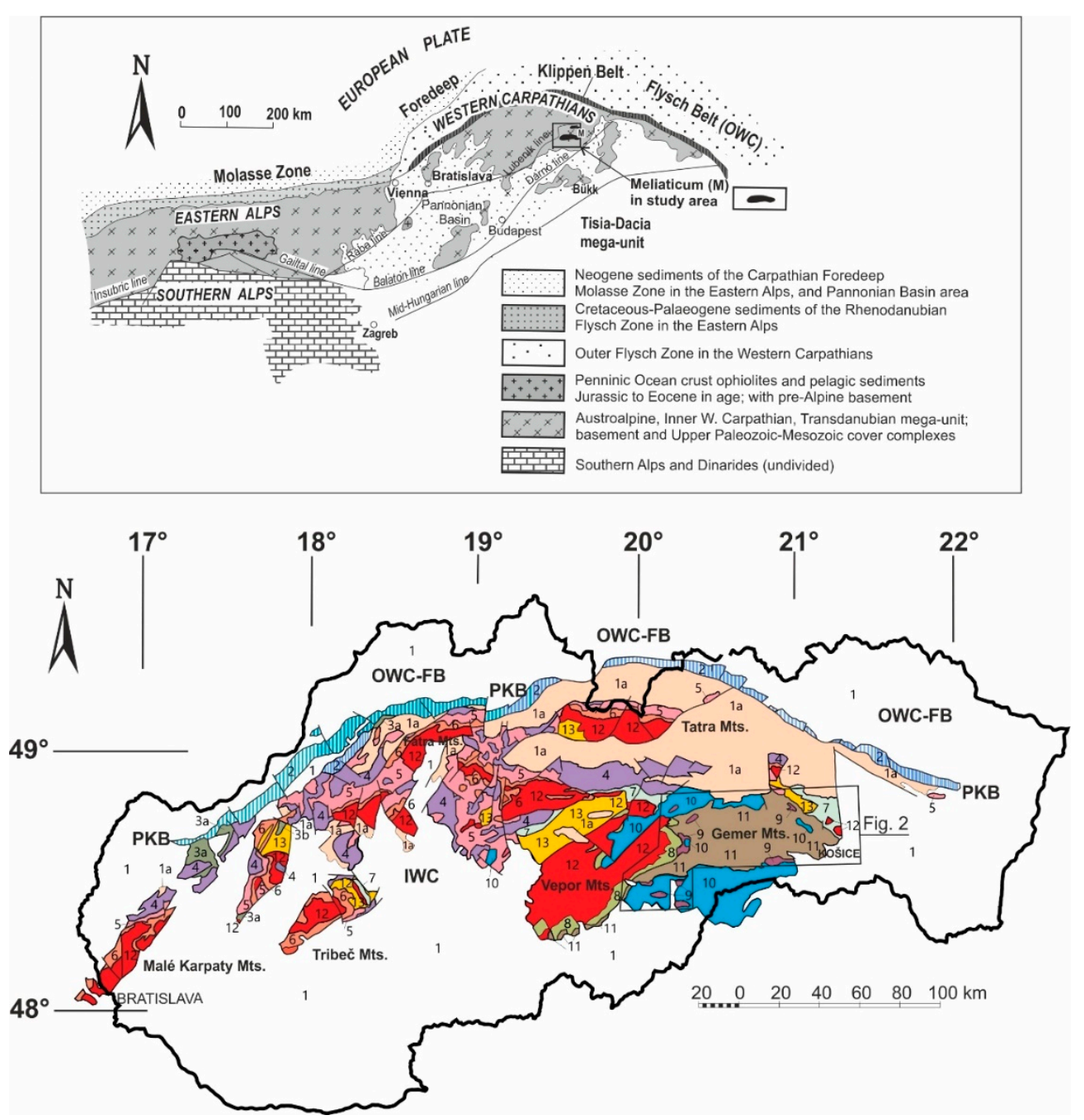

Figure 1. Position of the Western Carpathians and the schematic tectonic map of the Inner Western Carpathians (IWC, modified from [25]). 1-Quaternary and Cenozoic deposits undivided; Outer Western Carpathians Flysch Belt (OWC-FB); 1a-Paleogene deposits of the IWC; 2-Pieniny Klippen Belt (PKB); 3a-Upper Cretaceous to Eocene Gosau-type sediments; 3b-Upper Cretaceous Infratatric Succession; 4-Hronic nappes; 5-Fatric nappes; 6-Tatric cover; 7-North-Veporic cover; 8-South-Veporic cover; 9-Meliatic nappes; 10—Silicic nappes (including Turnaicum); 11-Gemeric Paleozoic basement (Variscan Lower Unit) and cover; 12-Variscan Upper Unit; and 13-Variscan Middle Unit. 
Equilibrium thermodynamics has proven powerful in geology in recent decades. Thermobarometers are progressively accompanied by thermodynamic modelling [26-31]. These techniques had a great impact on petrological studies even when samples were only partly equilibrated [32]. Widely used sets of activity-composition ( $\mathrm{a}-\mathrm{x})$ relationships originally included those developed for metapelitic or ultramafic rock modelling based on Holland and Powell datasets [28,33-36].

However, it remained difficult to model in metabasic lithologies because of the lack of the $a-x$ relationships suitable for modelling partial melting equilibria in metabasic rocks. The metabasite set is a part of the new HPx-eos thermodynamic models introduced in 2016 [37]. It has since been used and tested by several authors, e.g., [38-41]. Thermobarometry is very challenging, and a special Chlorite-Mica database was developed for low-grade metamorphic rocks lacking indexing minerals [42-44]. This was mostly used as a chlorite thermometer which enabled $\mathrm{XFe}^{3+} \mathrm{Chl}$ estimation at fixed pressure [43,45,46]. A similar approach was employed by [47] for K-white mica thermobarometry. This enabled P-T derivation by combining the Chl-Qtz- $\mathrm{H}_{2} \mathrm{O}$ thermometer and K-white mica Qtz- $\mathrm{H}_{2} \mathrm{O}$ barometer [43].

This paper collects new results from the assessment of $\mathrm{P}-\mathrm{T}$ data from the Meliaticum using Perple_X pseudosection modelling and geothermobarometry methods. The main issue herein is to test the new evolutionary model of Meliaticum proposed by [48] and define the metamorphic overprinting grade of Meliatic paleotectonic units incorporated in the Neotethyan Late Jurassic-Early Cretaceous accretionary wedge. The applied methods determined the precise metamorphic conditions of Meliaticum, despite this unit being incorporated in the Cretaceous orogenic wedge of the IWC.

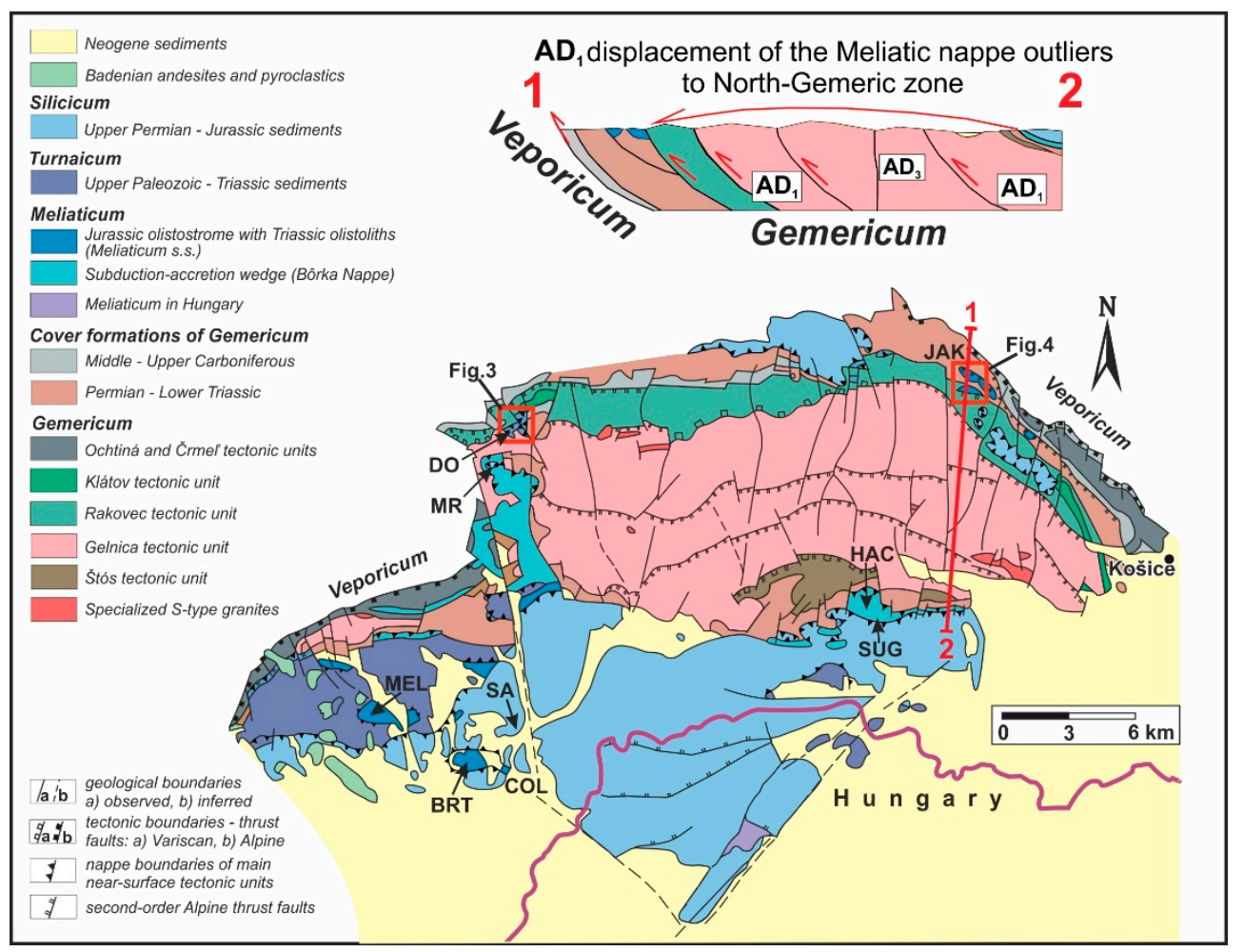

Figure 2. Tectonic map of the southeastern part of the IWC modified from $[49,50]$ with originally defined two Meliatic units. Schematic cross-section documents general northward thrusting of the Meliaticum (and Silicicum) over the Gemericum. The investigated areas are marked by sample group abbreviations for the Dobšiná (DO), Jaklovce (JAK), Malý Radzim Hill near Brdárka (MR), Meliata (MEL), Bretka (BRT), Čoltovo (COL), Hačava (HAC), Šugov Valley (SUG) and Gemerská Hôrka (SA-6) localities. For the displacement of the Meliatic nappe outliers and their meso- and microstructures, see Supplementary Figures S1-S8. 


\section{Geological Setting and Review of Previous Results}

Meliaticum was traditionally subdivided into the unsubducted Meliata and subducted Bôrka units $[8,9,11,15,51-55]$. The Meliatic Superunit ( Meliaticum) comprises, however, three principal paleotectonic units. These are the Bôrka Unit derived from the continental margin, the transitional Meliata Unit and the Jaklovce Unit oceanic margin crust [48].

\subsection{Lithostratigraphy and Geochemistry}

The Bôrka Unit (Figures 2 and 3) was defined as the Meliatic continental margin composed of a deeper shelf to slope facies of Middle to Upper Triassic/Lower Jurassic carbonatic and siliciclastic sediments interlayered with calc-alkaline basalts. The age of carbonates was confirmed by conodonts [11]. These are overlying the Permian-Lower Triassic siliciclastics associated with trachyrhyolites, trachyandesites, calc-alkaline rhyolites, dacites, and basalts developed on the Early Paleozoic (Gemeric type) basement rocks [8-10,12,25,51,53]. Metamorphosed rocks of this succession are incorporated in the Bôrka Nappe $[25,51,56]$.
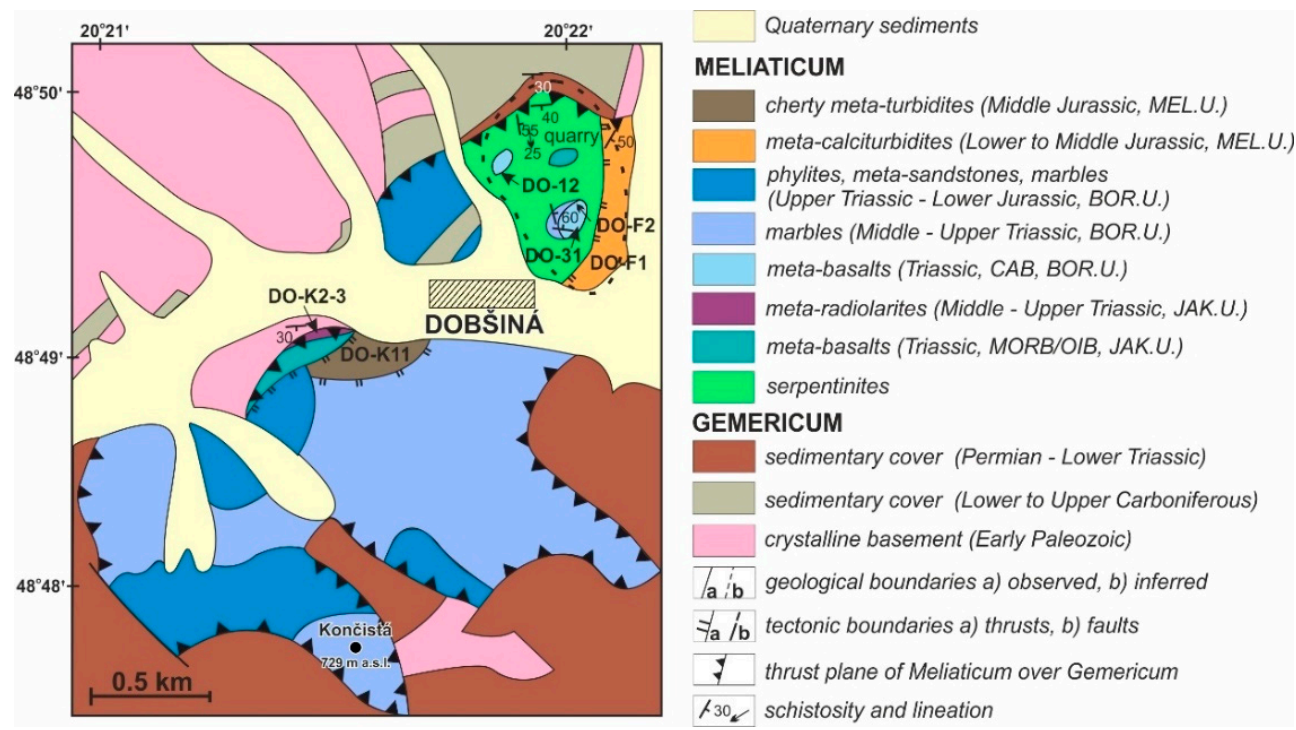

Figure 3. Schematic geological map from Dobšiná area with mélange blocks of the Meliatic paleotectonic units [48]. Modified from [48,50]. Dashed line-the limits of the quarry.

The Meliata Unit s.s. (Figure 4) was defined as a Middle Jurassic deep-water turbiditic siliciclastic to cherty succession interlayered with radiolarites [9]. This contains olistoliths of the Middle to Upper Triassic continental margin carbonates, rare mid-Triassic radiolarites [57] and OIB-type metabasalts [48] which build the Jurassic olistostromatic formations near Meliata and Čoltovo villages [9,52,58,59]. We recommended the use of the Meliata Unit for this part of Meliaticum and other equivalent remnants of sedimentary olistostromatic formations, where the metamorphic overprinting of the sedimentary matrix and olitoliths is nearly the same (see Section 2.2).

Quite different turbiditic sediments occur at Dobšiná and Jaklovce (Figures 3 and 5), where the carbonatic clastogeneous material $(\mathrm{Cal}, \pm \mathrm{Dol})$ clearly predominates an admixture of the siliciclastic one (Qtz, Ms, Chl). Due to tradition, we call both types of turbiditic sediments as siliciclastic or calciclastic flysch, respectively [48], also in this paper. 

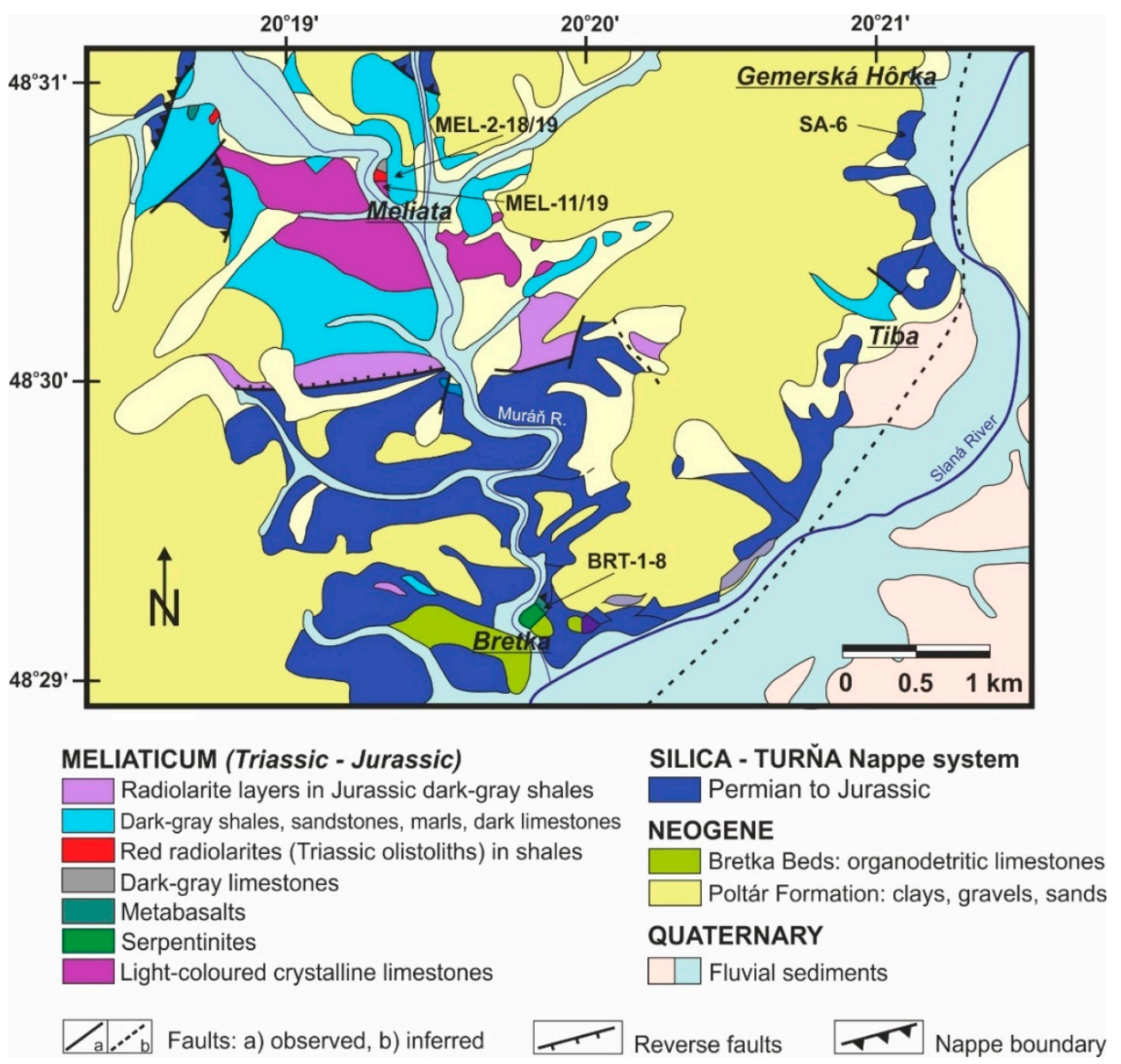

Figure 4. Schematic geological map of Meliata, Bretka and Gemerská Hôrka areas modified from [52]. The Meliaticum occurs in tectonic windows below the Silica-Turňa nappe system.
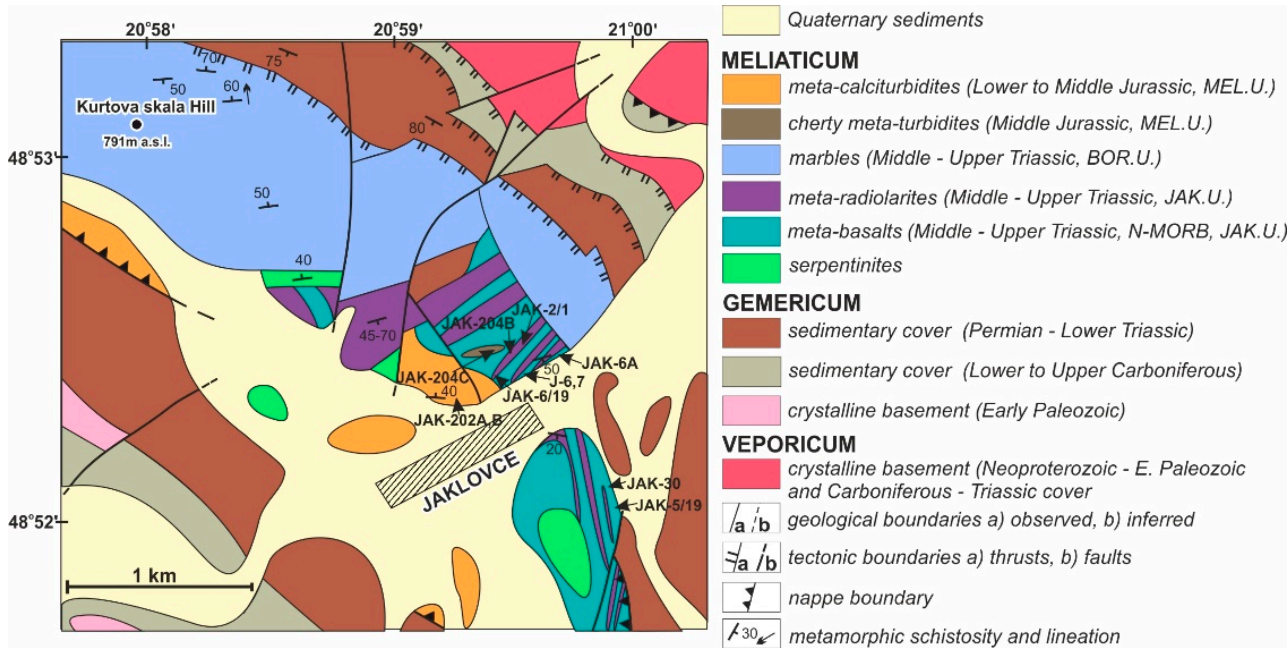

Figure 5. Schematic geological map of Meliaticum from the Jaklovce area (modified from [48,50]).

The Jaklovce Unit (Figure 5) is the most characteristic oceanic or ophiolitic sedimentary-magmatic succession of the Meliaticum composed of pelagic cherty sediments to radiolarites, N-MORBs and rare alkaline OIBs associated with serpentinised and rodingitised, mostly abyssal harzburgitic, mantle fragments $[9,11,14,15,53,60-62]$. The oceanic Jaklovce Succession was more precisely defined 
using our new biostratigraphic data from radiolarites and cherty carbonates which distinguished the Lower (Ladinian), Middle, and Upper (Carnian to Norian?) Beds [48]. The SIMS U/Pb detrital Zrn ages from pelagic sediments revealed Permian and Anisian magmatic zircon sources from a destructed continental margin [48]. Therefore, we recommended the use of the Jaklovce Unit for this unique oceanic, despite the incomplete ophiolitic paleotectonic Meliatic domain [48].

In addition to Triassic carbonates, the MOR type basalts and mid-Triassic radiolarites were considered to be large olistoliths in the Jaklovce Jurassic olistostromatic formation [11,12]. However, the grade of metamorphic overprinting of the inferred flysch matrix and the Middle to Upper Triassic olistoliths strongly differs ([48]; see Section 2.2). This does not match the Meliata Unit s.s. at the Meliata village type locality which contains pre-metamorphic Triassic olistoliths in the Jurassic flysch. Therefore, we acknowledge an accretionary wedge mélange at Jaklovce rather than an olistostromatic formation. Meta-ophiolitic fragments of the Jaklovce Unit achieved a variable degree of MP to HP/LT metamorphic overprinting which clearly occurred before they were tectonically juxtaposed with the Jurassic flysch VLT-LT/LP metasediments in the mélange [48]. The Jaklovce Unit typically occurs around the Jaklovce village, but also as a mélange block south of Dobšiná town (Figures 3 and 5).

\subsection{Metamorphism}

The Bôrka Nappe metabasites [63-66] underwent boundary greenschist to epidote-blueschists P-T conditions at $380-460^{\circ} \mathrm{C}$ and $1.0-1.3 \mathrm{GPa}$. Similar P-T estimates at $400-460{ }^{\circ} \mathrm{C}$ and $1.05-1.2 \mathrm{GPa}$ or $360-400^{\circ} \mathrm{C}$ at $0.8 \mathrm{GPa}$ were reported for glaucophane, pyroxene and chloritoid-bearing metapelitic to metapsammitic rocks [67]. These estimates are based on equilibrium conditions and calculations by using the Geo-Calc and Thermo-Calc software packages [68-70].

Further petrological and mineral chemistry study enabled to estimate $\mathrm{P}-\mathrm{T}$ conditions from basal parts of the Bôrka Nappe in a quantitative phase diagram (PT pseudosections) contoured by mineral composition, $\mathrm{H}_{2} \mathrm{O}$ mode isopleths, and with garnet-phengite thermometry [71]. The pseudosection modelling in Thermo-Calc software [72] estimated peak blueschist-facies conditions at $520-620^{\circ} \mathrm{C}$ and 1.1-1.4 GPa [71].

The 600 MPa pressure was estimated by [73] for Mrb, Fwn in Jaklovce MORB-type metabasalts [13,60] by the empiric geobarometer $\mathrm{Al}^{\mathrm{IV}}$ vs. $\mathrm{Na}^{\mathrm{B}}$ of [74].

The Meliata Unit s.s. has a relatively weaker metamorphic overprinting at approximately $250-350^{\circ} \mathrm{C}$ and 350-540 MPa according to Kübler's index and chlorite-phengite geothermobarometry [54].

The oceanic slivers of the inferred Meliaticum in northeastern Hungary are embedded in Permian sediments of Perkupa Formation at the base of the Silica Nappe (Figure 2). These Bódva Valley ophiolitic metagabbros provided minimum pressures of 700-800 $\mathrm{MPa}$ at $350-500{ }^{\circ} \mathrm{C}$ and almost isothermal decompression of 400-600 MPa in the greenschist facies. The following metamorphic event in the albite-epidote-amphibolite facies was characterised by a temperature increase up to $500-600{ }^{\circ} \mathrm{C}$ in isobaric conditions [75,76]. Similar fragments of serpentinites, as well as gabbroic and doleritic rocks embedded in Permian salinar formation of the Silica Nappe hanging wall, were found in the Držkovce (DRŽ-1) borehole and in the area of Bohúňovo and Gemerská Hôrka areas in Slovakia (Figure 2) [77].

\subsection{Tectonic Evolution and Geochronology}

The Meliata Ocean closure and subduction of the continental and inferred oceanic crust was constrained in Bôrka Nappe to 160-150 Ma by ${ }^{40} \mathrm{Ar}-{ }^{39} \mathrm{Ar}$ [78-82] and K-Ar 155-152 Ma ages [82] of "phengitic" white micas from blueschist facies rocks. The Meliata Unit s.s. metasediments in Meliata village area have younger ${ }^{40} \mathrm{Ar}-{ }^{39} \mathrm{Ar}$ ages than the Bôrka Unit at 150-115 Ma [54,78-82] following the accretionary wedge formation between ca. 150 and $130 \mathrm{Ma}$. The exhumation stage at approximately $135 \mathrm{Ma}$ was determined by $\mathrm{U}-\mathrm{Pb}$ dating of metamorphic-metasomatic perovskite in serpentinised and rodingitised harzburgites [62,83]. This age is consistent with the EPMA Mnz age from the underlying South-Gemeric Unit [84] and indicates the overloading of the Gemeric Superunit with the exhumed Meliatic accretionary wedge [15]. The (U-Th)/He zircon ages (ZHe) from the Meliata Unit fragments 
document the polystage low-temperature thermal history of the Meliatic accretionary wedge during overthrusting the Gemeric Unit. The oldest ZHe cooling ages of 130-120 Ma from the southern-most Bôrka Unit nappe-outliers on Gemericum (Figure 2) were interpreted as the collapse of the Meliatic accretionary wedge due to initiated southward underthrusting of the South-Veporic and Gemeric continental margin thrust sheets $[15,85]$, the latter exhumed between ca. 105-85 Ma according to ${ }^{40} \mathrm{Ar}-{ }^{39} \mathrm{Ar}$ ages $[79,80,86]$. The ZHe ages from 115 to $95 \mathrm{Ma}$ show the postponed exhumation and cooling of some nappe slices in the Meliatic accretionary wedge overlying the Gemeric Unit [15]. The rutile SIMS U/Pb age of ca. $100 \mathrm{Ma}$ from a Jaklovce metabasite [48] falls into this interval. The Silica-type nappes reached the Gemeric and Veporic Unit at ca. $90-85 \mathrm{Ma}$ according to the ${ }^{40} \mathrm{Ar}-{ }^{39} \mathrm{Ar}$ ages of phlogopite from the Silicic Nappe sole [87]. The ZHe ages from 80 to $65 \mathrm{Ma}$ obtained from both the Meliatic and the underlying Gemeric Units can be interpreted as IWC orogenic wedge cooling [15]. These ages postdate Late Cretaceous compressional/transpressional burial or the infolding of the superficial Meliatic accretionary wedge fragments at ca. 100-80 Ma within the framework of the IWC orogenic wedge [15]. The exhumation and cooling of the southern Veporic Unit to $\sim 250-200{ }^{\circ} \mathrm{C}$ at 75-71 Ma by Zrn fission track was data-constrained [88,89].

The Meliatic accretionary wedge $[15,48]$ is dismembered in allochthonous blocks or nappe outliers overlying the Neo-Tethyan Meliatic Basin northern continental margin Gemeric Superunit and partly also the Veporic Superunit (Figure 2). Cretaceous tectonics of the Western Carpathians is characterised by north-vergent collision [90]. This northward thrust structure originated by collision-related crustal shortening that prograded from the Late Jurassic Meliata suture in the south towards the inferred Penninic (Atlantic Tethys, [91]) sutures during the Late Cretaceous to Early Paleogene on the IWC northern margin [85,90,92-94]. An interval of ca. $105-48 \mathrm{Ma}$ was recorded by ${ }^{40} \mathrm{Ar}-{ }^{39} \mathrm{Ar}$ ages for the Veporic and Tatric part of the IWC orogenic wedge [86].

Following the previous review of Meliaticum tectonometamorphic events documented by geochronological data, we used the D1 stage for a pre-collisional subduction-related evolutionary stage connected with a subductional burial to the MP and HP depths of the Meliatic Bôrka and Jaklovce paleotectonic units in a subduction channel. We then relate the D2 stage to the exhumation of these unit fragments into an accretionary wedge with the Meliata Unit flysch metasediments. The tectonic juxtaposition of all three metamorphosed paleotectonic units with a different metamorphic grade during the late D2 and D3 stages indicates the start of the transformation or break-up of the accretionary wedge into numerous mélange blocks which are displaced throughout the Gemeric Superunit as kilometre-size nappe outliers. The original position of the Meliatic paleotectonic units within the wedge is still under debate. Attempted reconstruction has recently been made by [48] using new litho-bio-stratigraphy, geochemistry (including the $\mathrm{Nd}$ isotope study), Zrn and Rt geochronology data and preliminary metamorphic grade estimates.

In describing the IWC's orogenic wedge evolutionary stages, we used the AD1 Alpine deformation-recrystallisation stage for the first compressional stage and nappe stacking, then AD2 for the extension- or transpression-related exhumation and thrusting, AD3 for the next compression/transpression and thrusting due to a foreland basin closure, when also conjugated northwest-southeast trending dextral shearing (called the Košice-Margecany shear zone) was combined with northeast-southwest trending shearing in the Trans-Gemeric shear zone (see Supplementary Figures S1-S4 and [15,93,95,96]).

The Meliaticum preserves the internal structure after the pre-AD1 D1 to D3 stages. It then shares evolution with the underlying Gemeric and Veporic superunits towards the north within the IWC orogenic wedge during the AD1 to AD3 stages (see Supplementary Figures S1-S8 as examples).

Abbreviations of the rock-forming minerals names used in the text, tables and figures are: $\mathrm{Ab}$-albite; Act-actinolite; Alm-almandine; Amp-amphibole; An-anorthite; Ap-apatite; Aug-augite; Bt_biotite; Cal—calcite; Cel-Ms—celadonite-rich Ms; Chl—chlorite; Cpx-clinopyroxene; Czo-clinozoisite; Dol—dolomite; Ed-edenite; Ep-epidote; Fwn-ferrowinchite; Gln-glaucophane; Grs-grossular; Grt-garnet; Ill-illite; Ilm-ilmenite; Kfs-potassium feldspar; Lws-lawsonite; 
Mhb-magnesio-hornblende; Mhs—magnesio-hastingsite; Mrbk—magnesio-riebeckite; Msmuscovite; $\mathrm{Ph}$-phengite ( Cel-Ms); Pl—plagioclase; Prg—pargasite; Py—pyrite; Qtz—quartz; Rbk—riebeckite; Rt—rutile; Sps—spessartine; Stp—stilpnomelane; Tlc-talc; Ts-tschermakite; $\mathrm{Tr}$ —-tremolite; Ttn—titanite; Wnc—winchite; Zo—zoisite; and Zrn—zircon.

\section{Methods}

The field investigation was focused on the collection of representative Triassic and Jurassic rock-types of the Meliatic continental and oceanic margin [48]. We selected suitable samples of metabasites, metacherts to metaradiolarites, marbles as well as calciclastic and siliciclastic flysch metasediments, respectively, for the P-T estimates. The mineral composition and textures of the studied rocks were first investigated in polished sections by polarised light microscope.

The mineral element compositions were measured by electron probe microanalysis (EPMA) on a Cameca SX-100 electron microprobe at the State Geological Institute of Dionýz Štúr in Bratislava, and by JEOL Super-probe JXA 8100 at the Earth Science Institute of the Slovak Academy of Sciences in Banská Bystrica. The voltage was accelerated by $15 \mathrm{kV}$, with a beam current of $20 \mathrm{nA}$ and a beam focused to $3-5 \mu \mathrm{m}$, and the following standards and measured lines were used: $\mathrm{Si}$ (TAP, K $\alpha$, wollastonite), $\mathrm{F}$ (LPCO, $\mathrm{K} \alpha, \mathrm{LiF}), \mathrm{Cl}\left(\mathrm{LPET}, \mathrm{K} \alpha, \mathrm{NaCl}\right.$ ), $\mathrm{Al}$ (TAP, $\mathrm{K} \alpha, \mathrm{Al}_{2} \mathrm{O}_{3}$ ), $\mathrm{Ca}$ (LPET, $\mathrm{K} \alpha$, apatite), $\mathrm{Fe}$ (LLIF, $\mathrm{K} \alpha$, fayalite), $\mathrm{Ti}\left(\mathrm{LLIF}, \mathrm{K} \alpha, \mathrm{TiO}_{2}\right.$ ), $\mathrm{K}$ (LPET, $\mathrm{K} \alpha$, orthoclase), $\mathrm{Na}$ (TAP, $\mathrm{K} \alpha$, albite), $\mathrm{Mg}$ (TAP, $\mathrm{K} \alpha$, forsterite), Mn (LLIF, K $\alpha$, rhodonite), $\mathrm{Cr}$ (LLIF, $\mathrm{K} \alpha, \mathrm{Cr}$ ), $\mathrm{Ni}$ (LLIF, $\mathrm{K} \alpha, \mathrm{Ni}$ ). Additionally, for carbonates and feldspars also $\mathrm{Sr}$ (LPET, $\mathrm{L} \alpha, \mathrm{SrTiO}_{3}$ ), $\mathrm{S}$ (LPET, $\mathrm{K} \alpha$, barite) and $\mathrm{Ba}$ (LPET, $\mathrm{L} \alpha$, barite) were used. For the carbonates $\mathrm{Mg}, \mathrm{Si}, \mathrm{Al}, \mathrm{Ca}, \mathrm{S}$ and $\mathrm{Mn}$, the following counting times were used: $10 \mathrm{~s}$ on peak and $5 \mathrm{~s}$ on background; Fe $20 \mathrm{~s}$ on peak and $10 \mathrm{~s}$ on background; $\mathrm{Sr} 60 \mathrm{~s}$ on peak and $30 \mathrm{~s}$ on background. For the micas $\mathrm{Na}, \mathrm{Si}, \mathrm{Al}, \mathrm{Mg}, \mathrm{F}, \mathrm{Cl}, \mathrm{K}, \mathrm{Ca}, \mathrm{Ti}, \mathrm{Fe}, \mathrm{Mn}$, and $\mathrm{Cr}$, the following counting times were used: $10 \mathrm{~s}$ on peak and $5 \mathrm{~s}$ on background; Ni $20 \mathrm{~s}$ on peak and $10 \mathrm{~s}$ on background. Detection limits were within $0.01-0.05 \mathrm{wt} . \%$ of oxide.

Garnet and amphibole crystal-chemical formulae were calculated using Excel spreadsheets as in $[97,98]$. The recalculation of the crystal formulae and chlorite classification was then performed by WinCcac Microsoft Windows program [99].

The Hačava blueschist sample (Bôrka Unit) pressures and temperatures were determined by combining thermodynamic modelling, Grt-Ph thermometry [100] and Si-in-Ph barometry (error $\pm 0.2 \mathrm{GPa}$ ) [101]. The HAC-1 sample P-T pseudosection was calculated at 0.5-2.0 GPa and $300-700{ }^{\circ} \mathrm{C}$ by the Perple_X version 6.9.0 computer program package released in May $2020[30,102]$. Calculations were performed using thermodynamic dataset [33].

The following solid-solution models were chosen: $\mathrm{cAmph}(\mathrm{G})$ for amphiboles, Gt(WPH) for garnet, $\mathrm{Chl}(\mathrm{W})$ for chlorite, Mica(W) for white mica, Ep(HP11) for clinozoisite-epidote and feldspar for feldspars. Pure phases included lawsonite, titanite, rutile, quartz and $\mathrm{H}_{2} \mathrm{O}$. The thermodynamic modelling was based on our previously published whole-rock composition and classification data [48]. This was then calculated under the 11-component $\mathrm{MnO}-\mathrm{Na}_{2} \mathrm{O}-\mathrm{CaO}-\mathrm{K}_{2} \mathrm{O}-\mathrm{FeO}-\mathrm{MgO}-\mathrm{Al}_{2} \mathrm{O}_{3}-\mathrm{SiO}_{2}-\mathrm{H}_{2} \mathrm{O}-\mathrm{TiO}_{2}-\mathrm{O}_{2}$ (MnNCKFMASHTO) system. The chemical composition of Ms (Cel) and Grt (Sps-Alm-Grs) was used for the isopleths and P-T estimation.

The original rock composition was slightly modified to fit this 11-component system: (1) CaO was reduced according to the bulk-rock phosphorous content, and assuming that these elements are bound exclusively to ideally composed apatite; (2) $\mathrm{Fe}^{2+} / \mathrm{Fe}^{3+}$ ratio for calculation was set to molar bulk rock $\mathrm{Fe}_{2} \mathrm{O}_{3} /\left(\mathrm{Fe}_{2} \mathrm{O}_{3}+\mathrm{FeO}\right)$ value of 0.1 [103-105]; (3) the fluid was considered to be in excess, owing to the observations outlined by [106] that hydrated metabasites contain approximately 5-6 wt. $\% \mathrm{H}_{2} \mathrm{O}$ in the blueschist facies and (4) the bulk-rock compositions used for modelling were converted from weight $\%$ oxides to molar $\%$ oxides. A similar approach was used for the JAK-30 sample (Jaklovce Unit) calculation with the following changes: the 11-component system was simplified by ommiting $\mathrm{MnO}$ due to the lack of any significant Mn-bearing phase. Whole-rock compositions were calculated 
from representative metamorphic mineral assemblage following the modal composition of $25 \%$ Act, 25\% Ab, 22\% Chl, 5\% Ph, 10\% Ep, 10\% Cal and 3\% Ttn.

Pseudosections were contoured with isopleths for various chemical parameters using Perple_X werami and pstable sub-programs to supply raw data. The final pseudosections and contoured $\mathrm{P}-\mathrm{T}$ diagrams were redrawn, and the mineral assemblage data at specific $\mathrm{P}-\mathrm{T}$ conditions were supplied by Perple_X werami. Pressure uncertainties for assemblage field boundaries are approximately $\pm 0.1 \mathrm{GPa}$ at the $2 \sigma$ level [107].

The MathWorks MATLAB script created by [43] was used for Chl-Ph-Qtz- $\mathrm{H}_{2} \mathrm{O}$ multiequilibria geothermobarometry with the Std state and solid solutions for chlorite [43] and mica [47]. Calculations were performed under the NCKFMASHO $\left(\mathrm{Na}_{2} \mathrm{O}-\mathrm{CaO}-\mathrm{K}_{2} \mathrm{O}-\mathrm{FeO}-\mathrm{MgO}-\mathrm{Al}_{2} \mathrm{O}_{3}-\mathrm{SiO}_{2}-\mathrm{H}_{2} \mathrm{O}\right)$ chemical system. This employed muscovite, $\mathrm{Mg}$ and Fe-celadonite, $\alpha$-quartz, mica end-members and clinochlore, daphnite, sudoite, $\mathrm{Mg}$ and Fe-amesite and pyrophyllite chlorite end-members. The water activity of $\mathrm{H}_{2} \mathrm{O}=1$ was used for the calculations of all samples.

Multiequilibria geothermobarometry was followed by using a chlorite thermometer (error $\pm 10-30^{\circ} \mathrm{C}$ ) [108] based on $\mathrm{Al}^{\mathrm{VI}}$ content or Cal-Dol solvus thermometry (error $\pm 20-25^{\circ} \mathrm{C}$ ) [109] combined with Si-in-Phg barometry [101]. Crystal formulae re-calculation and Chl classification and thermometry was by WinCcac Microsoft Windows program [99]. The geothermobarometry of relic magmatic amphiboles was performed by the geothermobarometer of [110].

Finally, powder X-ray diffraction (PXRD) analysis was determined by BRUKER D8 Advance diffractometer (Laboratory of X-ray diffraction SOLIPHA, Comenius University in Bratislava, Faculty of Natural Sciences) under the following conditions: Bragg-Brentano geometry (Theta-2Theta), $\mathrm{Cu}$ anticathode $(\mathrm{K} \alpha 1=1.5406 \AA)$ with a $40 \mathrm{kV}$ accelerating voltage and $40 \mathrm{~mA}$ beam current. Ni $\mathrm{K} \beta$ filters were used for stripping $\mathrm{K} \beta$ radiation, and data were obtained by BRUKER LynxEye detector. The step size was $0.01^{\circ} 2 \theta$, the counting time was 3 s per step, and the measurement ranged from $2^{\circ}$ to $65^{\circ} 2 \theta$. The quantitative analysis of mineral phases and peak-shape fitting using pseudo-Voight function were performed with DIFFRACplus TOPAS software (version 4.1).

\section{Results}

\subsection{Petrography of Metamorphic Rocks}

\subsubsection{Bôrka Unit}

The Bôrka Nappe metabasalts and associated rocks from the following samples; Hačava (s. HAC-1; Figures 2 and 6A), Šugov Valley (s. SUG-10; Figures 2 and 6B-D), the Dobšiná block north of Dobšiná town (s. DO-31, DO-12; Figures 3 and 6E,F) bear signatures of blueschist-facies metamorphism. They typically contain Grt, Gln, Ph, $\pm \mathrm{Ep}, \pm \mathrm{Ab}, \pm \mathrm{Chl}$ and \pm Tlc assemblages. The Grt blueschists of the Hačava and Šugov Valley alternate with the pale Middle to Upper Triassic marbles.

Metamorphic textures of blueschists are distinctly schistose, and often preserve relic bands and lenses from the inferred peak metamorphic D1-maximum burial stage. The metamorphic schistosity of these domains is defined by Gln, Ph and Grt (Figure 6A). The superimposed post-peak D2 secondary schistosity contains fine-grained $\mathrm{Gln}, \mathrm{Ph} / \mathrm{Ms}, \mathrm{Chl}, \pm \mathrm{Bt}$, Ep, Ab (Figure 6C,D). Biotite replaces Ph and Gln and is often partly replaced by Chl. The boudination of competent blueschist layers in softer marble matrix is also characteristic. The blueschist lenses are rounded $\delta$-clasts due to rotation in marble matrix during the D2 exhumation shearing, thus indicating the "top-to-the north" movement (Figure 6B). Layers of calc-alkaline blueschists often occur in marbles and Tlc-Chl-Ph-Cal schists in the Dobšiná quarry (Figures 3 and 6E,F). Phengite-rich layers formed on the contact of blueschists with serpentinite (Figure 6F). 

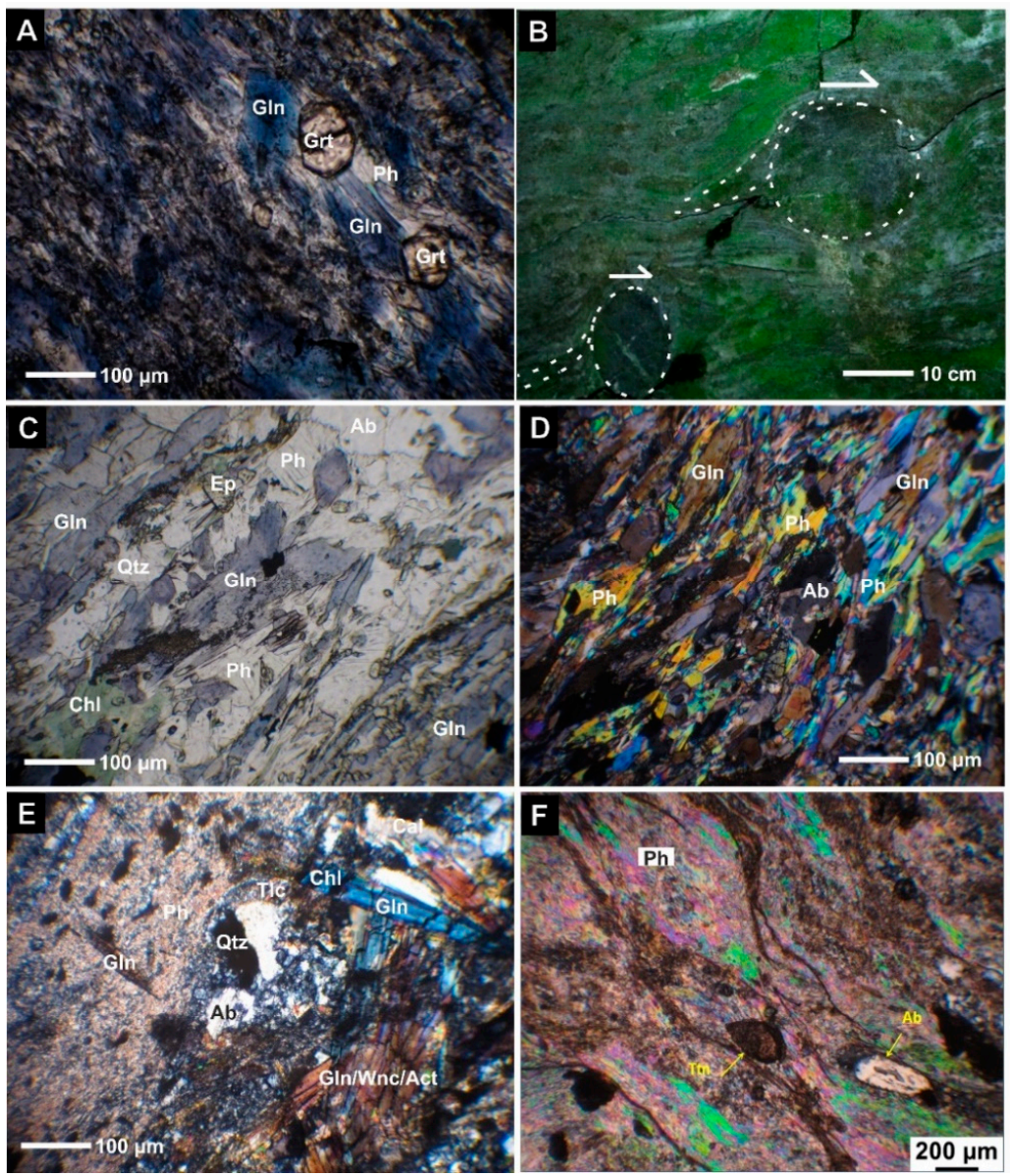

Figure 6. Examples of the Bôrka Unit blueschists: (A) metamorphic schistosity of relic D1 bands and lenses defined by the Gln-Ph-Grt assemblage of the metamorphic peak D1 stage from Hačava blueschist (s. HAC-1); (B) blueschist $\delta$-clasts with tails in marble. Top-to-the north-vergency exhumation (D2) shearing of Šugov Valley blueschists (s. SUG-10); (C,D) mineral assemblage of s. SUG-10 after the D1 and D2 stages; (E) mineral composition of s. DO-31; (F) Ph-rich layer in blueschist s. DO-12. Pictures A and $C$ taken at II N; D-F at $X \mathrm{~N}$.

Samples DO-12 and DO-31 are lensoidal to spherical blueschist metric fragments associated with serpentinised peridotites, rodingites, marbles and Tlc-Chl-Ph-Cal schists within the soft serpentinitic matrix exposed in the Dobšiná quarry (Figure 3). The blueschist textures are weakly to strongly schistose, composed of $\mathrm{Gln}, \mathrm{Ph}, \mathrm{Chl}, \mathrm{Ab}, \mathrm{Ep}, \mathrm{Ap}$ and Ttn. This large serpentinitic mélange block is in tectonic contact with an overlying sheet of Jurassic meta-calciclastic turbidites (Figure 3). In contrast, the Meliata MEL-11/19-investigated marble block sample from the inferred Bôrka Unit is located within the Meliata Unit flysch metasediments at Meliata village (see Section 4.1.3).

\subsubsection{Jaklovce Unit}

$\mathrm{N}-\mathrm{MORB}$ type metabasalts and metadolerites alternate with cherty schists, cherty metacarbonates and metaradiolarites at Jaklovce village (Figure 5). The thickness of the metabasalt/metadolerite layers varies from a few decimetres to the first metres. Kilometre-size blocks of this metamorphosed oceanic succession lie between the Meliata Unit Jurassic flysch metasediments and a large sheet of the Bôrka Unit continental margin Kurtova skala Hill Triassic marbles. A similar oceanic succession also occurs in a mélange block south of Dobšiná town. This succession is overlain by siliciclastic turbiditic metasediments of the Meliata Unit Jurassic flysch and the Bôrka Unit Triassic marbles in the Končistá Hill area (Figure 3). 
The relic magmatic ophitic and occasional amygdaloidal texture in metabasites is crosscut by metamorphic veins (Figure 7A-H). This is a unique feature of these low-temperature metamorphosed basalts (Figure 7A,B) and dolerites (Figure 7C,D) which exhibit both relic magmatic and superimposed metamorphic textures. Magmatic $\mathrm{Cpx}$ and lath-shape $\mathrm{Pl}$ are constituent minerals, and metamorphic overprinting is observed only in the networks of veins and veinlets or the metamorphic matrix composed of newly formed Chl, Ep, Cal, Ab and Amp (Act, less Wnc or Rbk) \pm Qtz (Figure 7E-H).
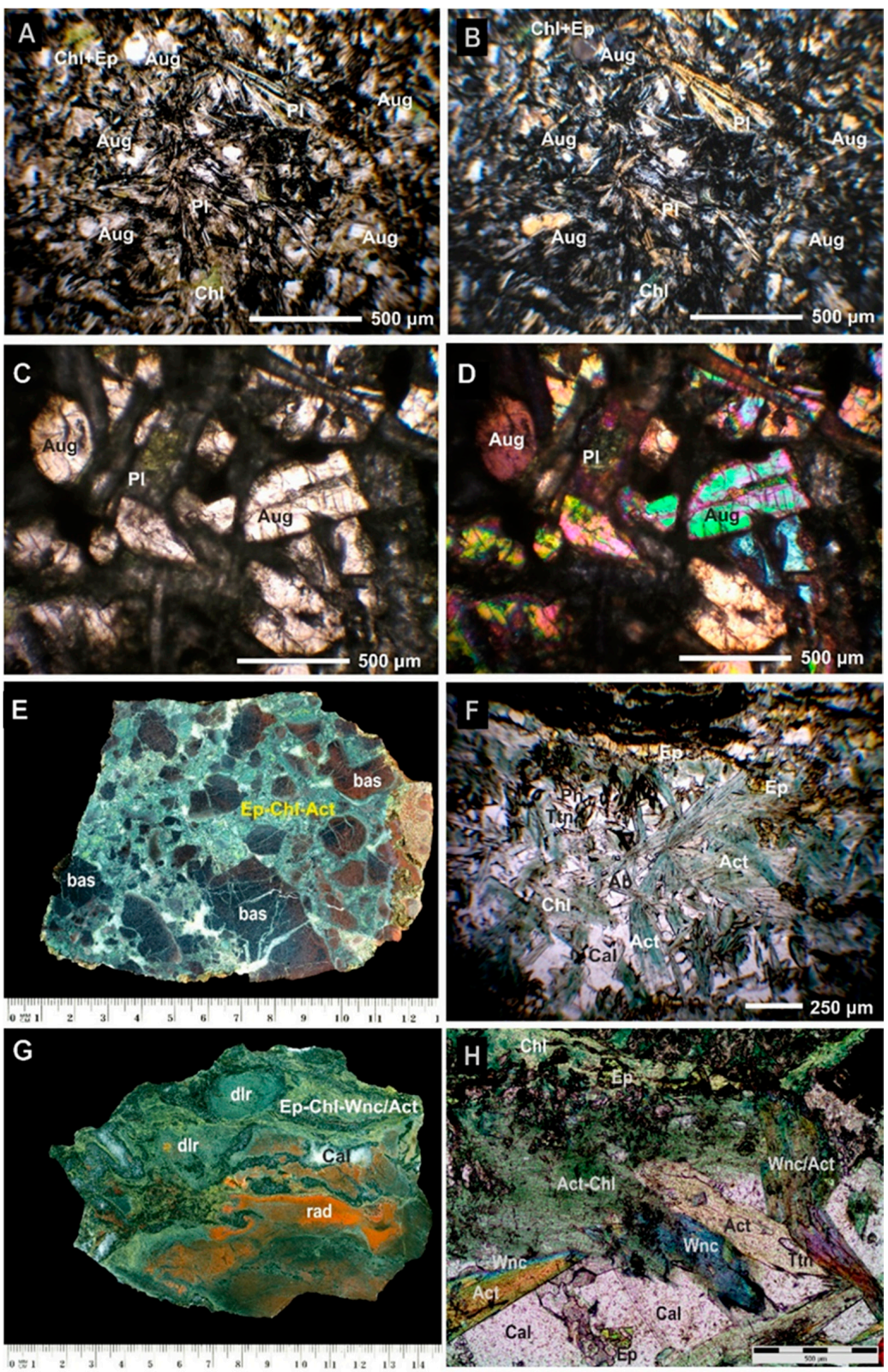

Figure 7. Images of the Jaklovce Unit metabasalt and metadolerite textures: (A,B) metabasalt (s. JAK-30) with a relic ophitic texture of $\mathrm{Cpx}$ and radially distributed albitised Pl. Clinopyroxene (Aug) is partly replaced by $\mathrm{Chl}$ and Ep; (C,D) Metadolerite (s. JAK-6B) with a relic ophitic texture of Cpx and albitised $\mathrm{Pl}$; (E) metabasalt breccia (s. JAK-5/19) composed of dark metabasalt (bas) fragments enclosed in a greenish metamorphic matrix (Act, Chl, Ep/Czo, Ab, Cal, Ttn); (F) metamorphic veinlet in metabasalt (s. JAK-5/19) composed of blue-green Act, Chl, Ep, Ab, Ph, Cal and Ttn; (G) fragment of metadolerite (dlr, s. J-6) enclosing reddish metaradiolarite (rad) in a metamorphic matrix of Wnc/Act, Chl, Ep, $\mathrm{Cal}$ and $\mathrm{Ab}$; and (H) metamorphic veinlet in metadolerite (s. J-6) is composed of Wnc/Act, Chl, Ep, Ab, Cal and Ttn. Pictures A, C, F and $\mathrm{H}$ at $I I \mathrm{~N} ; \mathrm{B}$ and $\mathrm{D}$ at $X \mathrm{~N}$. 
Metabasalts to metadolerites are interlayered with cherty schists to metaradiolarites (Figure 8A-D) and rarely with reddish cherty metacarbonates (Figure 8E). Only sample MR-1 has obvious HP blueschist facies metamorphic overprinting after blue Amp-rich (Gln) aggregates (Figures 2 and 8F).
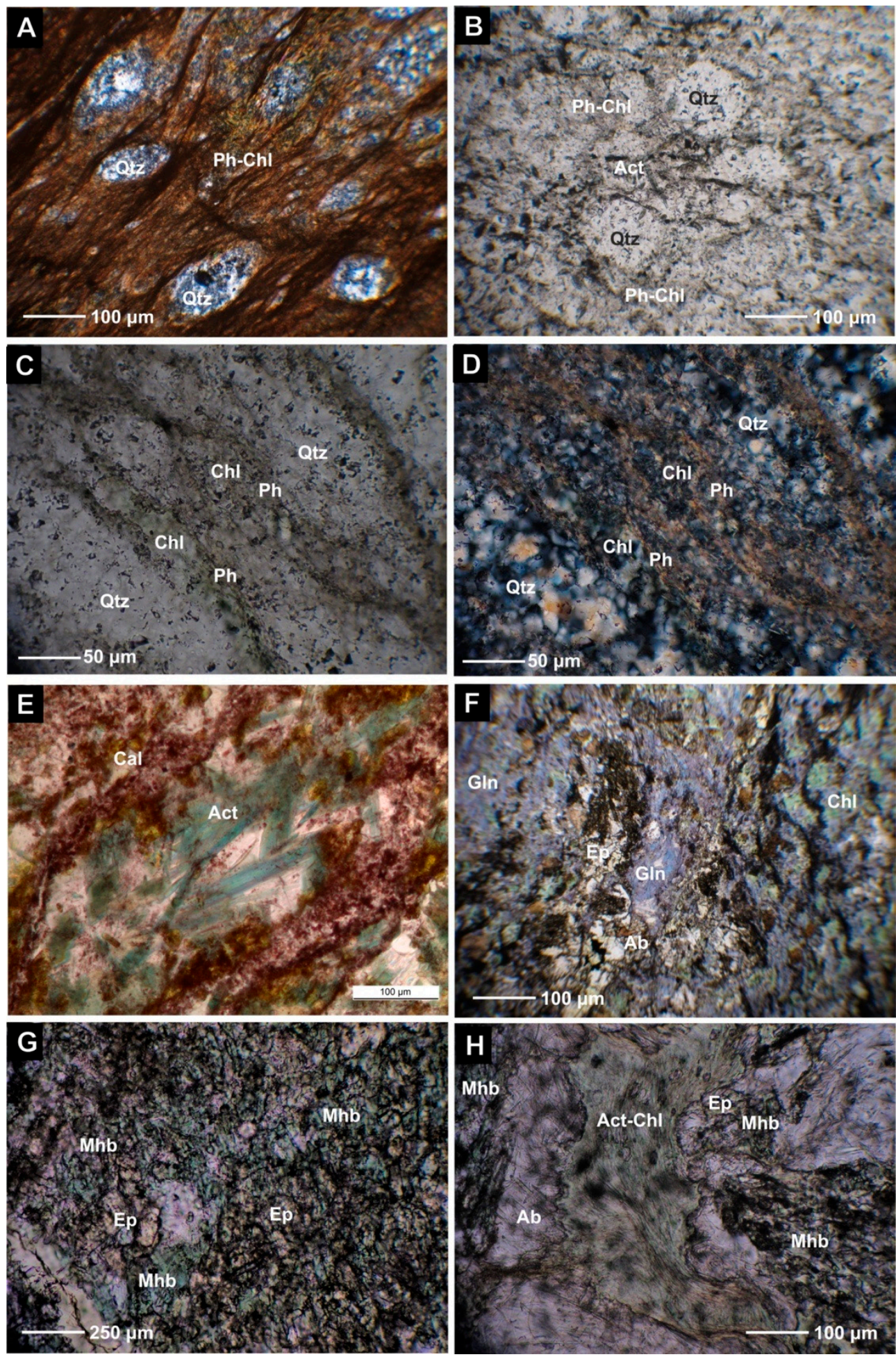

Figure 8. Metamorphic textures of the Jaklovce Unit rocks: (A-D) impure metaradiolarites (s. JAK-6/19 in A, and s. DO-K2 in B-D) with newly formed Qtz, Chl, Ph, \pm Act; (E) a reddish cherty metacarbonate layer with blue-green Act after basaltic tuff admixture (s. JAK-2/1); (F) blueschist (s. MR-1) facies metabasalt with blue Gln, Chl, Ep and Ab; and (G,H) Mhb amphibolite (s. BRT-1) is crosscut by an Act-Chl-Cal-Ab veinlet. Pictures B, C and E-H at II N; A and D at X N. 
The Bretka locality mélange block contains metabasalts associated with serpentinites. Some metabasalt fragments have alternating dark carbonatic schists which highlight the greenschist facies metamorphic overprinting assemblage of Chl, Act, Ab, Ep/Czo and Cal. Other metabasalt fragments composed of Mhb, Ep, Czo, Ab-Pl, Ap and Ttn are metamorphosed in epidote-amphibolite facies. Amphibolites are crosscut by veinlets with greenschist facies mineral assemblages (s. BRT-1; Figures 4 and $8 \mathrm{G}, \mathrm{H})$.

The inferred Jaklovce paleotectonic unit MEL-15 and COL-1 samples OIB type basaltic blocks and the Bôrka paleotectonic unit MEL-11/19 sample-type Triassic carbonate blocks occur as olistoliths in the Jurassic siliciclastic and cherty flysch metasediments of the Meliata Unit at Meliata and Coltovo villages (Figures 2 and 4).

\subsubsection{Meliata Unit}

The investigated blocks of metabasalts and metaradiolarites of the Bôrka and Jaklovce units are tectonically juxtaposed with Jurassic calciclastic (Figure 9A) or siliclastic (Figure 9B) flysch metasediments of the Meliata Unit in the Jaklovce mélange (Figure 5). The main part of the Jaklovce Unit oceanic thrust-sheet tectonically overlies the Meliata Unit flysch metasediments. The small metric-size sedimentary matrix exposures of siliciclastic flysch of a sample type JAK-204C in Figure 5 are rarely present along contacts of the oceanic crust rigid mélange blocks. Calciclastic flysch metasediments from Jaklovce (Figures 5, 9A and 10A,B; s. JAK-202A,B) petrographically closely resemble those from the Dobšiná quarry (Figures 3 and 10C; s. DO-F1,F2).
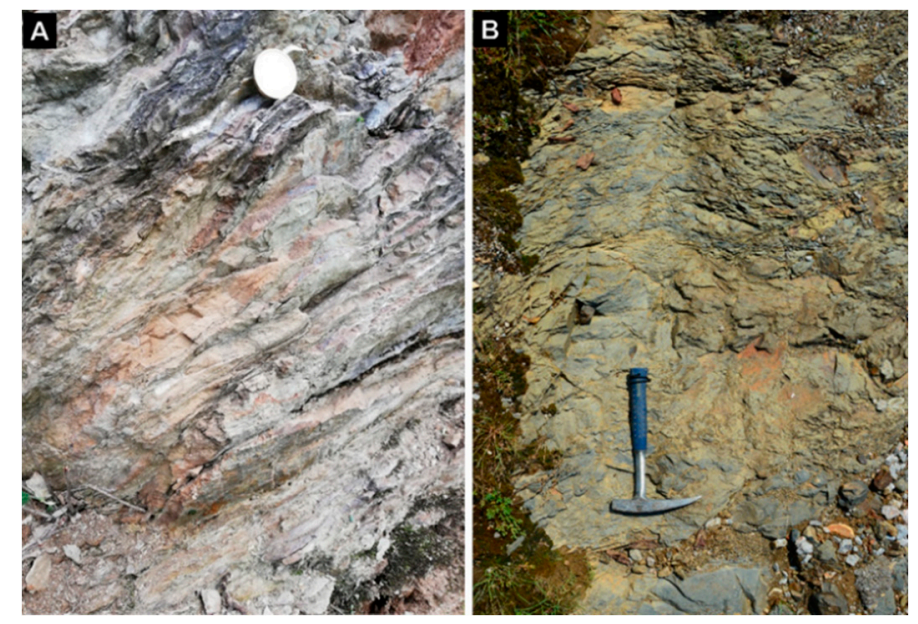

Figure 9. Types of Jurassic flysch metasediments in the Meliata Unit: (A) calciclastic flysch at Jaklovce village ( $0.5 \mathrm{~m}$ photo width); and (B) siliciclastic flysch composed of dark cherty schists with radiolarites at Meliata village.

Different slightly metamorphosed Jurassic dark clayey to cherty shales or siliciclastic flysch (Figures 9 and 10D; s. MEL-2/19) with dark (Figure 10E; s. MEL-14/19) and green (Figure 10F; s. MEL-17B/19) radiolarite layers prevail at Meliata village. This type of siliciclastic flysch, typical of Meliata locality, only locally occurs at Dobšiná-Končistá (Figure 3; s. DO-K11) and Jaklovce (Figure 5; s. JAK-204C) areas. 

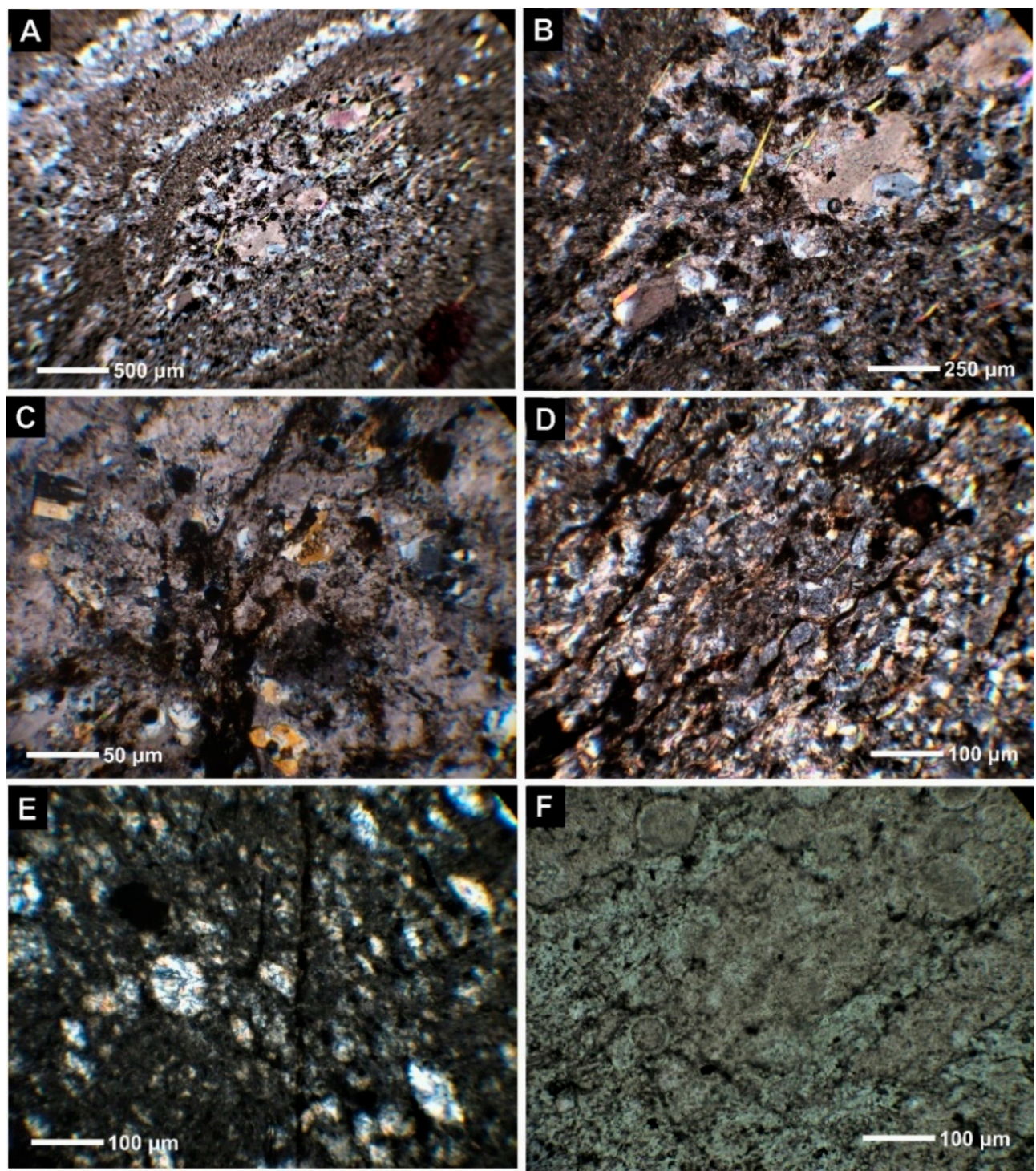

Figure 10. Meliata Unit rock textures: (A,B) calciclastic flysch metasediments at Jaklovce (s. JAK-202A); recrystallised coarse-grained layers contain newly formed $\mathrm{Cal}, \mathrm{Dol}, \mathrm{Ab}, \mathrm{Kfs}$ and $\mathrm{Ms}$ clasts; (C) recrystallised coarse-grained layers of carbonates with $\mathrm{Ab}$ in calciclastic flysch metasediments at Dobšiná (s. DO-F1); (D) cherty siliciclastic flysch metasediments (s. MEL-2/19) at Meliata village; (E) chalcedony to mosaic Qtz pseudomorphs after flattened and stretched radiolarians in a dark red Triassic (meta)radiolarite olistolith in the flysch (s. MEL-17B/19); and (F) greenish newly formed Chl-bearing metaradiolarite layers in flysch metasediments at Meliata with less deformed radiolarians (s. MEL-14/19). Picture F at II N; A-E at X N.

\subsubsection{Silica Nappe Hanging Wall Mélange}

Rare metagabbroic blocks occur in a salinar mélange in the Silica Nappe hanging wall at Gemerská Hôrka (Figure 4). The mafic rocks with well preserved mineral relics of coarse-grained $\mathrm{Hbl}$ and albitised $\mathrm{Pl}$ most likely have magmatic origin. These rocks' textures reveal a younger mineral assemblage of bluish Amp, Ep, Ab, Chl \pm Cal, \pm Qtz. Finally, a newer Amp generation replaces the brownish Amp along the rims or in crosscutting veinlets (Figure $11 \mathrm{~A}, \mathrm{~B}$ ). 

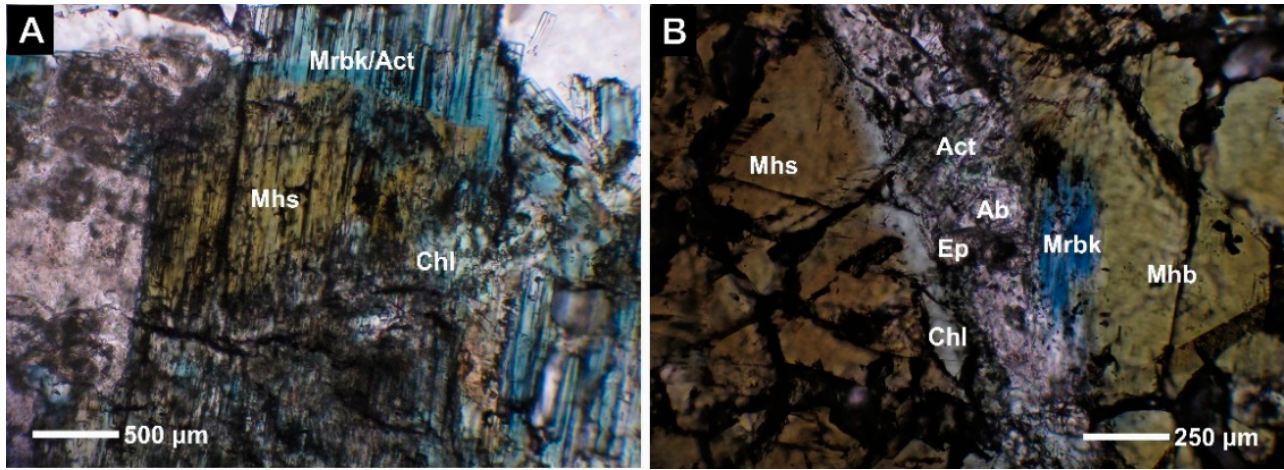

Figure 11. Metagabbro block in Permian evaporitic sediments of the Silica Nappe at Gemerská Hôrka (s. SA-6): (A) magmatic brown amphibole (Mhs) overgrown by metamorphic bluish Amp (Mrbk/Act); (B) brown amphibole (Mhs, Mhb) crosscut by the metamorphic veinlet of bluish Amp (Mrbk), colour-less Act, Ep, Ab and pale-green Chl. Pictures A and B at II N.

\subsection{Mineral Chemistry}

\subsubsection{Clinopyroxene}

Metabasites and metadolerites of the Jaklovce Unit have well preserved magmatic textures composed of augitic Cpx and Pl (Figure 12A-D and Figure 13).
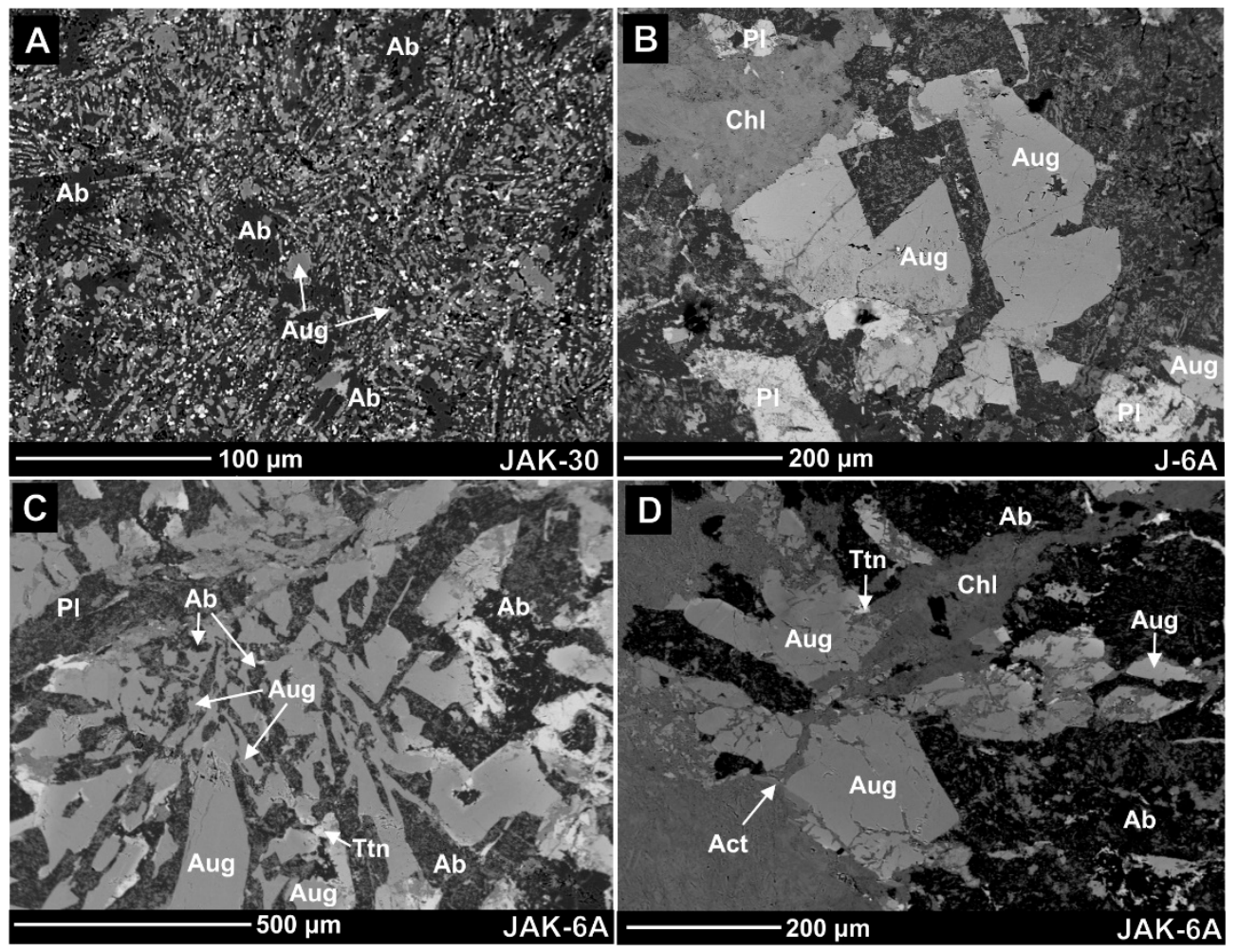

Figure 12. BSE images of the relic magmatic textures from the Jaklovce Unit metabasalts and metadolerites: (A) fine-grained metabasalt (s. JAK-30) with a well preserved ophitic texture of Aug and albitised Pl; (B) metadolerite (s. J-6A) with partly chloritised porphyric Aug and albitised Pl in Aug and $\mathrm{Pl} / \mathrm{Ab}$ fine grained matrix; $(\mathrm{C})$ dolerite texture (s. JAK-6A) with intergrown Aug and Pl; and (D) metadolerite (s. JAK-6A) crosscut by a metamorphic Chl-Act veinlet. 


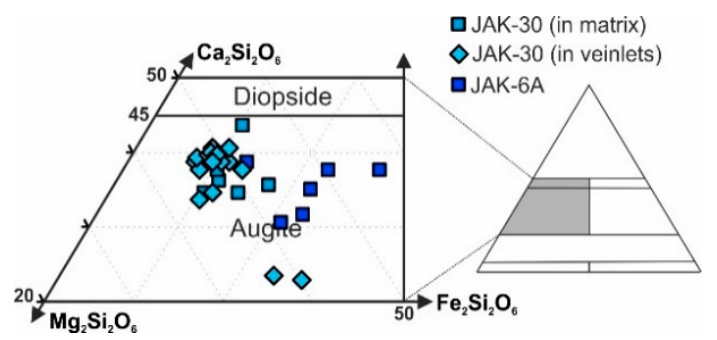

Figure 13. Classification diagram of magmatic clinopyroxene (Aug) from the Jaklovce Unit metabasalts and metadolerites.

The JAK-30 sample Aug in the fine-grained basalt has very little variation in the $\mathrm{En}_{45-54} \mathrm{Fs}_{9-18} \mathrm{Wo}_{35-44}$ composition (Figure 13). In addition, the JAK-6A Aug in dolerite is similar, but has a greater variation in the $\mathrm{Fe}-\mathrm{Mg}$ content $\left(\mathrm{En}_{32-39} \mathrm{Fs}_{14-30} \mathrm{Wo}_{31-39}\right.$, Figure 13). The decreased $\mathrm{Al}$ from 7.63 to $3.23 \mathrm{wt} . \%$ and Ti from 1.67 to $0.63 \mathrm{wt} . \%$ from the core to rim is obvious in the basalt porphyric Aug. There is also a small decrease in dolerite porphyric Aug from 3.8 to $2.2 \mathrm{wt} . \% \mathrm{Al}_{2} \mathrm{O}_{3}$ and from 1.8 to $0.5 \mathrm{wt} . \% \mathrm{TiO}_{2}$ (Table 1). The Aug intergrown with $\mathrm{Pl}$ also has a lower $\mathrm{Al}$ and Ti content. This most likely reflects the final magmatic crystallisation. The $\mathrm{Cr}_{2} \mathrm{O}_{3}$ content approaches $0.7 \mathrm{wt} . \%$ in all samples.

Table 1. Representative analyses of augitic clinopyroxene from the Jaklovce Unit.

\begin{tabular}{|c|c|c|c|c|c|c|c|c|c|c|}
\hline Sample: & JAK-30 & JAK-30 & JAK-30 & JAK-30 & JAK-30 & JAK-30 & JAK-30 & JAK-6A & JAK6-A & J6-A \\
\hline Mineral & Aug & Aug-(c) & Aug-(r) & Aug & Aug & Aug & Aug & Aug-(c) & Aug-(r) & Aug \\
\hline An. N.: & 3 & 4 & 5 & 3 & 6 & 7 & 18 & 3 & 2 & 4 \\
\hline Tectonic U.: & \multicolumn{10}{|c|}{ Jaklovce Unit } \\
\hline $\mathrm{SiO}_{2}$ & 52.56 & 49.95 & 49.12 & 47.97 & 52.05 & 50.15 & 49.41 & 51.55 & 48.28 & 51.08 \\
\hline $\mathrm{TiO}_{2}$ & 0.97 & 0.83 & 1.40 & 1.83 & 0.82 & 1.25 & 0.01 & 1.00 & 1.82 & 1.17 \\
\hline $\mathrm{Al}_{2} \mathrm{O}_{3}$ & 7.37 & 4.53 & 5.49 & 7.09 & 2.79 & 5.20 & 5.06 & 3.05 & 3.84 & 2.13 \\
\hline $\mathrm{Cr}_{2} \mathrm{O}_{3}$ & 0.21 & 0.00 & 0.06 & 0.06 & 0.12 & 0.13 & 0.02 & 0.21 & 0.03 & 0.00 \\
\hline $\mathrm{Fe}_{2} \mathrm{O}_{3}{ }^{*}$ & 0.00 & 3.27 & 2.39 & 1.86 & 0.86 & 1.33 & 5.89 & 0.90 & 3.67 & 0.62 \\
\hline $\mathrm{FeO}$ & 5.53 & 7.66 & 6.27 & 7.12 & 6.85 & 6.73 & 13.16 & 8.38 & 11.63 & 14.05 \\
\hline $\mathrm{MnO}$ & 0.15 & 0.29 & 0.23 & 0.19 & 0.21 & 0.19 & 0.44 & 0.20 & 0.37 & 0.40 \\
\hline $\mathrm{MgO}$ & 12.43 & 14.89 & 15.53 & 13.86 & 16.50 & 16.46 & 12.67 & 15.42 & 14.10 & 12.36 \\
\hline $\mathrm{CaO}$ & 18.10 & 17.45 & 18.79 & 19.60 & 19.71 & 18.59 & 11.95 & 19.46 & 15.97 & 18.53 \\
\hline $\mathrm{Na}_{2} \mathrm{O}$ & 2.44 & 0.76 & 0.37 & 0.40 & 0.26 & 0.22 & 1.02 & 0.34 & 0.39 & 0.41 \\
\hline Total & 99.79 & 99.68 & 99.66 & 99.98 & 100.18 & 100.27 & 100.67 & 100.52 & 100.10 & 100.76 \\
\hline $\mathrm{Si}^{4+}$ & 1.919 & 1.860 & 1.820 & 1.781 & 1.913 & 1.840 & 1.862 & 1.902 & 1.824 & 1.926 \\
\hline $\mathrm{Al}^{3+}$ & 0.081 & 0.140 & 0.180 & 0.219 & 0.087 & 0.160 & 0.138 & 0.098 & 0.171 & 0.074 \\
\hline$\Sigma$ & 2.00 & 2.00 & 2.00 & 2.00 & 2.00 & 2.00 & 2.00 & 2.00 & 2.00 & 2.00 \\
\hline $\mathrm{Ti}^{4+}$ & 0.027 & 0.023 & 0.039 & 0.051 & 0.023 & 0.035 & 0.000 & 0.028 & 0.052 & 0.033 \\
\hline $\mathrm{Al}^{3+}$ & 0.236 & 0.058 & 0.060 & 0.092 & 0.034 & 0.065 & 0.087 & 0.035 & 0.000 & 0.020 \\
\hline $\mathrm{Fe}^{3+}$ & 0.000 & 0.092 & 0.067 & 0.052 & 0.024 & 0.037 & 0.167 & 0.025 & 0.104 & 0.017 \\
\hline $\mathrm{Cr}^{3+}$ & 0.006 & 0.000 & 0.002 & 0.002 & 0.003 & 0.004 & 0.000 & 0.006 & 0.001 & 0.000 \\
\hline $\mathrm{Fe}^{2+}$ & 0.056 & 0.000 & 0.000 & 0.036 & 0.013 & 0.000 & 0.033 & 0.058 & 0.049 & 0.234 \\
\hline $\mathrm{Mg}^{2+}$ & 0.676 & 0.827 & 0.832 & 0.767 & 0.904 & 0.860 & 0.712 & 0.848 & 0.794 & 0.695 \\
\hline $\mathrm{Mn}^{2+}$ & 0.000 & 0.000 & 0.000 & 0.000 & 0.000 & 0.000 & 0.000 & 0.000 & 0.000 & 0.000 \\
\hline$\Sigma$ & 1.00 & 1.00 & 1.00 & 1.00 & 1.00 & 1.00 & 1.00 & 1.00 & 1.00 & 1.00 \\
\hline $\mathrm{Fe}^{2+}$ & 0.113 & 0.238 & 0.194 & 0.185 & 0.198 & 0.206 & 0.382 & 0.200 & 0.319 & 0.209 \\
\hline $\mathrm{Mn}^{2+}$ & 0.005 & 0.009 & 0.007 & 0.006 & 0.006 & 0.006 & 0.014 & 0.006 & 0.012 & 0.013 \\
\hline $\mathrm{Mg}^{2+}$ & 0.000 & 0.000 & 0.025 & 0.000 & 0.000 & 0.041 & 0.000 & 0.000 & 0.000 & 0.000 \\
\hline $\mathrm{Ca}^{2+}$ & 0.708 & 0.696 & 0.746 & 0.780 & 0.776 & 0.731 & 0.482 & 0.769 & 0.646 & 0.749 \\
\hline $\mathrm{Na}^{+}$ & 0.173 & 0.055 & 0.027 & 0.029 & 0.019 & 0.016 & 0.075 & 0.024 & 0.028 & 0.030 \\
\hline$\Sigma$ & 1.00 & 1.00 & 1.00 & 1.00 & 1.00 & 1.00 & 1.00 & 1.00 & 1.00 & 1.00 \\
\hline Total & 4.00 & 4.00 & 4.00 & 4.00 & 4.00 & 4.00 & 4.00 & 4.00 & 4.00 & 4.00 \\
\hline Wo & 0.65 & 0.58 & 0.61 & 0.61 & 0.71 & 0.61 & 0.35 & 0.70 & 0.53 & 0.71 \\
\hline En & 0.68 & 0.83 & 0.86 & 0.77 & 0.90 & 0.90 & 0.71 & 0.85 & 0.79 & 0.69 \\
\hline Fs & 0.17 & 0.24 & 0.19 & 0.22 & 0.21 & 0.21 & 0.41 & 0.26 & 0.37 & 0.44 \\
\hline
\end{tabular}

The pyroxene analyses calculations are based on 4 cations. $\mathrm{Fe}_{2} \mathrm{O}_{3}{ }^{*}$-ferric iron recalculated back to oxide from a.p.f.u. values. 
Augitic Cpx is partly preserved in metamorphic veinlets (Figure $14 \mathrm{~A}-\mathrm{F}$ ). Its remnants are enclosed in metamorphic Act which has a small sodium content-most likely inherited from Aug (Figure 14C-F). The composition of Aug in veinlets mostly overlaps with porphyric Aug $\left(\mathrm{En}_{48-55} \mathrm{Fs}_{8-14} \mathrm{Wo}_{34-41}\right)$ (Figure 13). $\mathrm{Al}_{2} \mathrm{O}_{3}$ varies from 2.8 to $7.0 \mathrm{wt}$ \% and $\mathrm{TiO}_{2}$ from 0.8 to $1.8 \mathrm{wt}$ \%, and the $\mathrm{Cr}_{2} \mathrm{O}$ content reaches $0.5 \mathrm{wt} . \%$. (Table 1). Irregular Aug relics in metamorphic Act (Figure 14E,F) contain a small amount of $\mathrm{Na}_{2} \mathrm{O}$ up to $1.0 \mathrm{wt}$ \% $\%$ and generally a have lower $\mathrm{CaO}$ content up to 12.0 wt.\% (Figure 13).
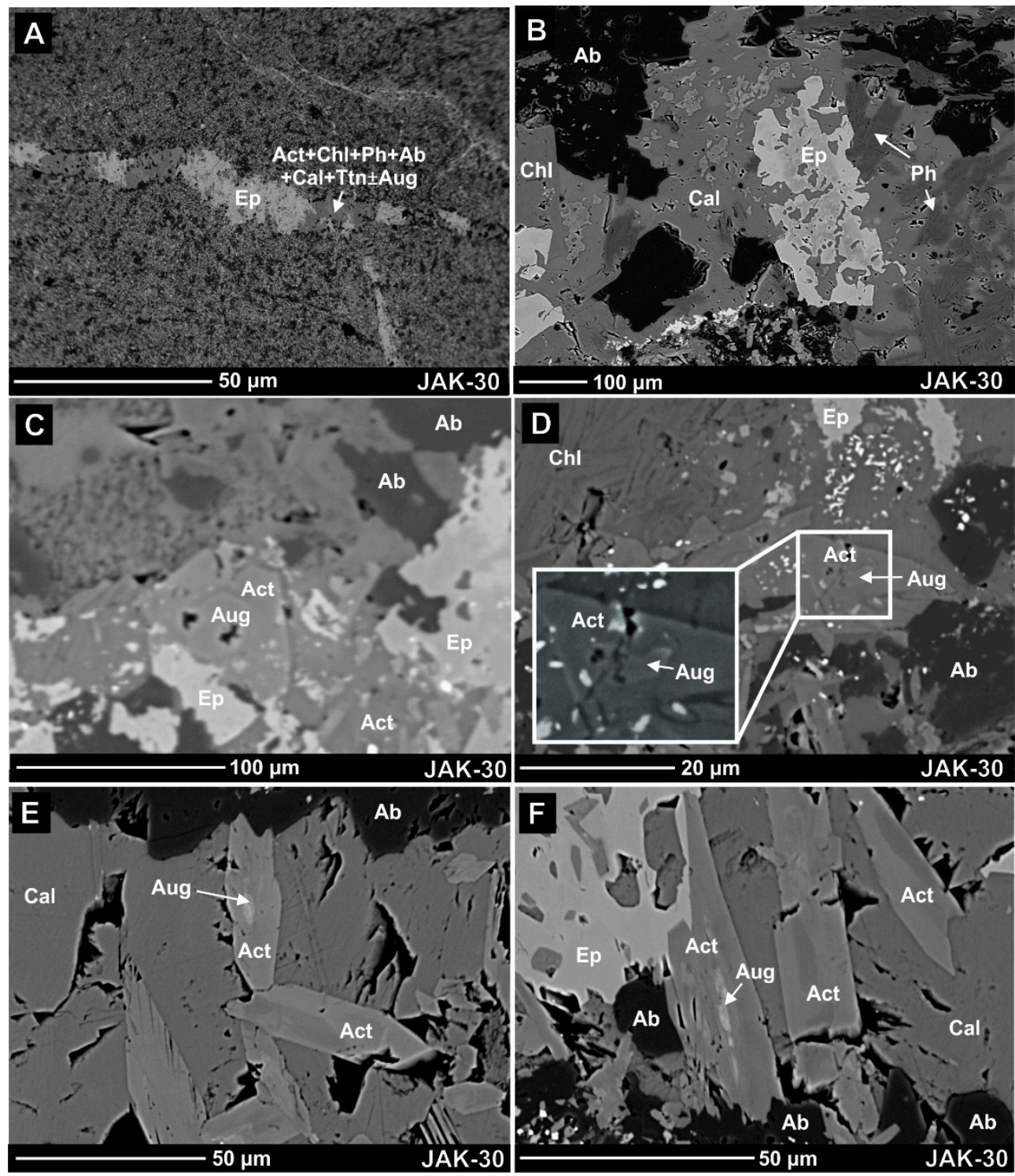

Figure 14. BSE images of the relic magmatic Aug in the metamorphic veins of metabasalt sample JAK-30 in the Jaklovce Unit: (A) fine-grained (meta)basalt crosscut by metamorphic veinlet composed of Chl, Act, Ep, Ab, Cal with relics of Aug; (B) detail of the Chl, Ep, Ab, Cal and Ph metamorphic veinlet; (C,D) relics of magmatic Aug overgrown by Act in a metamorphic veinlet; $(\mathbf{E}, \mathbf{F})$ irregular relics of Aug in metamorphic Act.

\subsubsection{Garnet}

Garnet belongs to the D1 assemblage of blueschists (Figure 15A,B; Table 2) and has a typical Sps/Alm-rich composition (Alm ${ }_{39-55} \mathrm{Sps}_{20-41} \mathrm{Grs}_{17-25}$ ) (Figure 16A). 


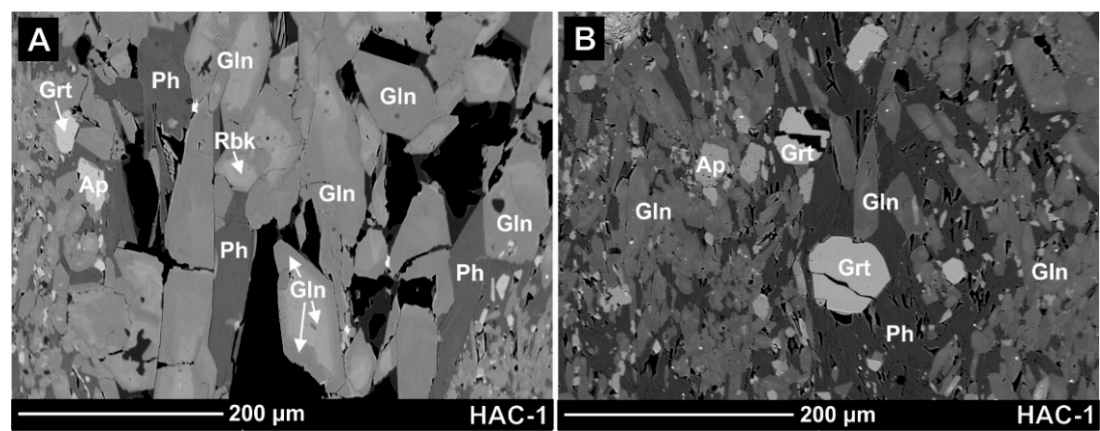

Figure 15. BSE images from the Hačava metabasalts of the Bôrka Unit: $(\mathbf{A}, \mathbf{B})$ the Gln-Ph-Grt assemblage of the peak (D1) metamorphic stage seen in blueschist at Hačava village.

Table 2. Representative analyses of the garnet from the Bôrka Unit.

\begin{tabular}{|c|c|c|c|c|c|c|c|}
\hline Sample: & HAC-2 & HAC-2 & HAC-2 & HAC-2 & HAC-2 & HAC-2 & HAC-2 \\
\hline Mineral & Grt-(r) & Grt-(t) & Grt-(c) & Grt-(c) & Grt-(c) & Grt-(t) & Grt-(r) \\
\hline An. N.: & 1 & 2 & 3 & 5 & 7 & 10 & 3 \\
\hline Tectonic U.: & & & & Bôrka Unit & & & \\
\hline $\mathrm{SiO}_{2}$ & 37.61 & 36.89 & 36.82 & 37.23 & 37.38 & 37.09 & 37.30 \\
\hline $\mathrm{TiO}_{2}$ & 0.09 & 0.18 & 0.19 & 0.17 & 0.19 & 0.13 & 0.09 \\
\hline $\mathrm{Al}_{2} \mathrm{O}_{3}$ & 20.21 & 19.85 & 19.65 & 19.65 & 19.96 & 19.90 & 20.30 \\
\hline $\mathrm{Cr}_{2} \mathrm{O}_{3}$ & 0.00 & 0.02 & 0.03 & 0.01 & 0.04 & 0.01 & 0.00 \\
\hline $\mathrm{FeO}$ & 24.28 & 21.47 & 19.26 & 18.54 & 19.16 & 20.51 & 23.97 \\
\hline $\mathrm{MnO}$ & 8.82 & 12.69 & 16.35 & 16.55 & 15.87 & 14.52 & 8.62 \\
\hline $\mathrm{MgO}$ & 0.32 & 0.23 & 0.21 & 0.16 & 0.18 & 0.19 & 0.38 \\
\hline $\mathrm{CaO}$ & 9.15 & 8.55 & 7.45 & 8.12 & 7.98 & 8.14 & 9.15 \\
\hline $\mathrm{Na}_{2} \mathrm{O}$ & 0.12 & 0.00 & 0.02 & 0.04 & 0.03 & 0.00 & 0.02 \\
\hline Total & 100.59 & 99.87 & 99.99 & 100.47 & 100.79 & 100.51 & 99.83 \\
\hline $\mathrm{Si}^{4+}$ & 3.015 & 2.992 & 2.993 & 3.007 & 3.008 & 2.993 & 3.012 \\
\hline $\mathrm{Ti}^{4+}$ & 0.005 & 0.011 & 0.012 & 0.010 & 0.011 & 0.008 & 0.005 \\
\hline $\mathrm{Al}^{3+}$ & 1.910 & 1.897 & 1.882 & 1.870 & 1.893 & 1.893 & 1.933 \\
\hline $\mathrm{Cr}^{3+}$ & 0.000 & 0.001 & 0.002 & 0.001 & 0.003 & 0.001 & 0.000 \\
\hline $\mathrm{Fe}^{3+}$ & 0.067 & 0.096 & 0.110 & 0.101 & 0.070 & 0.104 & 0.035 \\
\hline $\mathrm{Fe}^{2+}$ & 1.561 & 1.360 & 1.198 & 1.152 & 1.220 & 1.280 & 1.584 \\
\hline $\mathrm{Mg}^{2+}$ & 0.039 & 0.028 & 0.025 & 0.018 & 0.022 & 0.023 & 0.046 \\
\hline $\mathrm{Mn}^{2+}$ & 0.599 & 0.872 & 1.125 & 1.132 & 1.082 & 0.993 & 0.590 \\
\hline $\mathrm{Ca}^{2+}$ & 0.786 & 0.743 & 0.649 & 0.703 & 0.688 & 0.704 & 0.792 \\
\hline $\mathrm{Na}^{+}$ & 0.018 & 0.000 & 0.003 & 0.006 & 0.004 & 0.000 & 0.003 \\
\hline Total & 8.00 & 8.00 & 8.00 & 8.00 & 8.00 & 8.00 & 8.00 \\
\hline Alm & 0.55 & 0.48 & 0.43 & 0.41 & 0.43 & 0.46 & 0.55 \\
\hline Sps & 0.21 & 0.31 & 0.40 & 0.40 & 0.38 & 0.35 & 0.20 \\
\hline Grs & 0.24 & 0.21 & 0.17 & 0.19 & 0.19 & 0.19 & 0.25 \\
\hline
\end{tabular}

Garnet analyses calculations are based on 8 cations. (c) — crystal core; (r)—crystal rim; (t) —a transitional area between the crystal core and the rim.

Garnet in metabasalts exhibits prograde zoning, however, this is not observable on BSE images (Figure 16B). The Mn content in Grt decreases (MnO 16.35-8.82 wt.\%, Sps $41-20$ ) and the Fe content increases (FeO 19.26-24.35 wt.\%, Alm $39-55$ ) from the core towards the crystal rim (Figure 16A,C; Table 2). While Ca shows less variation, there is a gradual increase in Ca content (CaO 7.45-9.15 wt.\%, Grs $17-25)$ towards the crystal rim (Figure 16D; Table 2). The Grt Mg content is typically very low at up to $0.32 \mathrm{wt} . \%$, with an indistinct rim to core variation (Figure 16E; Table 2).

\subsubsection{Amphiboles}

Composition of the Bôrka Unit blueschist amphiboles (Figure 15A,B and Figure 17A) mainly corresponds to Gln and Rbk, but extends into Wnc and Act fields (Figure 18A-E; Table 3). Amphibole chemical analyses create a trend almost parallel with the Tr-Gln joint (Figure 18D,E). This documents high-pressure Gln to Rbk, medium-pressure Wnc or lower-pressure Act. 

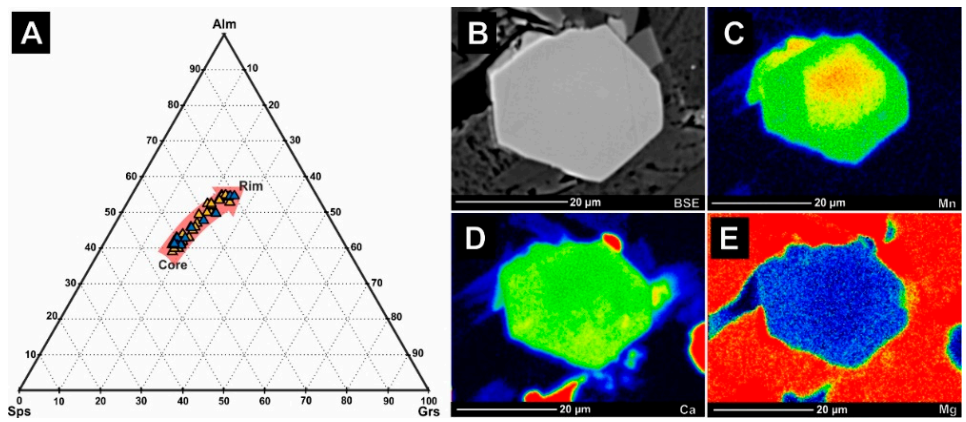

Figure 16. (A) Compositional diagram of Grt from the Bôrka Unit Hačava blueschist (s. HAC-1): the arrow shows a compositional change in the Grt from the crystal core to the rim. Blue triangles represent analyses from the analytical profile through the garnet crystal (Table 2); and (B) the BSE image of Grt used in X-ray element mapping: (C-E) Grt X-ray Mn, Ca and Mg element maps. Colour scale: blue-low concentration, red-high concentration.
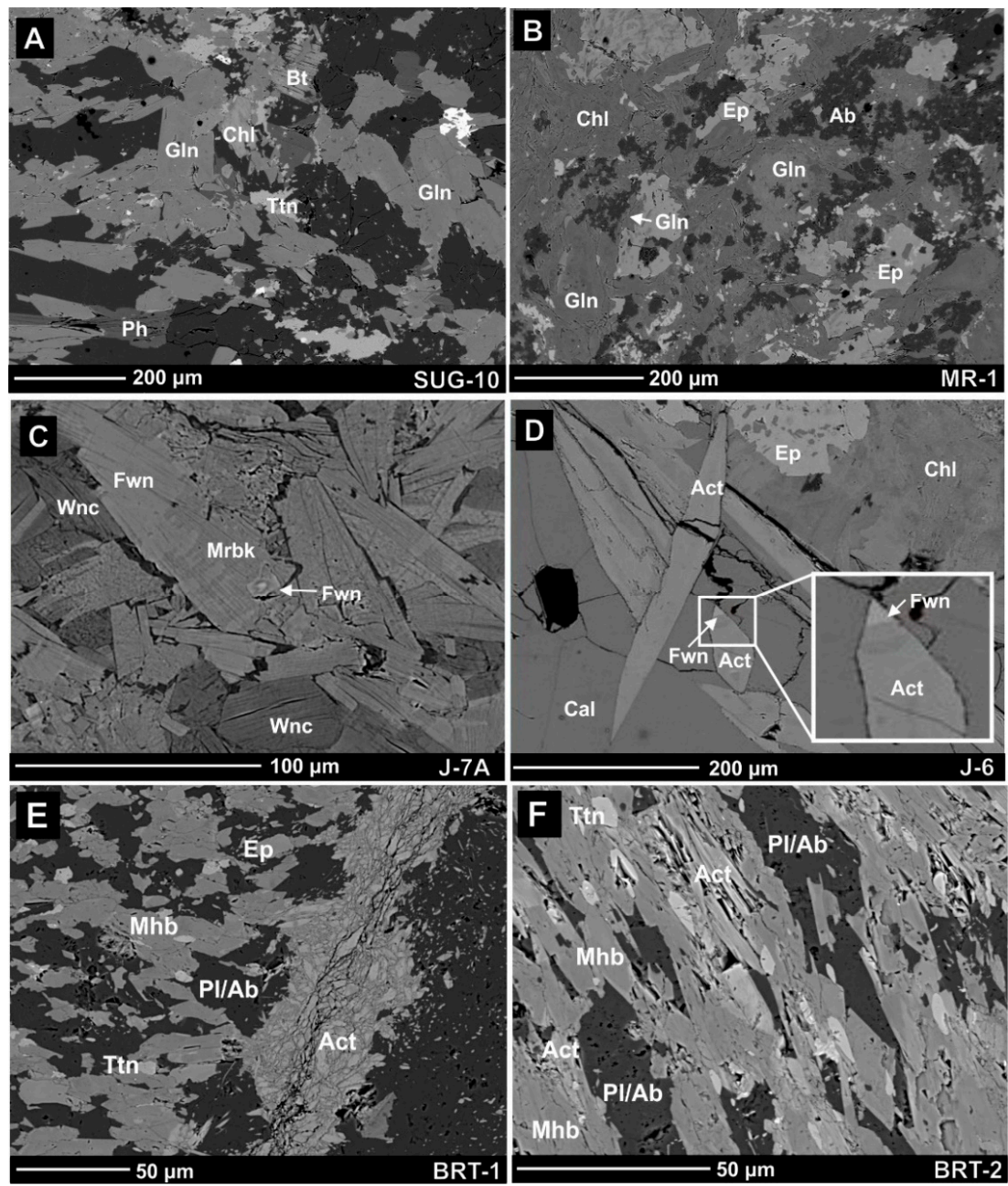

Figure 17. BSE images from the Bôrka Unit (A) and Jaklovce Unit (B-F) metabasites: (A) Gln-Ph assemblage of the peak (D1) metamorphic stage from blueschist in the Šugov Valley near Medzev village; (B) high-pressure Gln metabasite in Malý Radzim at Brdárka; (C,D) Jaklovce medium-to high-pressure Fwn/Wnc to Mrbk metabasalts; (E,F) Mhb amphibolites from the Bretka ophiolitic block hanging wall with a retrograde Act, $\mathrm{Ab}, \mathrm{Ep}$ and Ttn greenschist facies overprinting. 

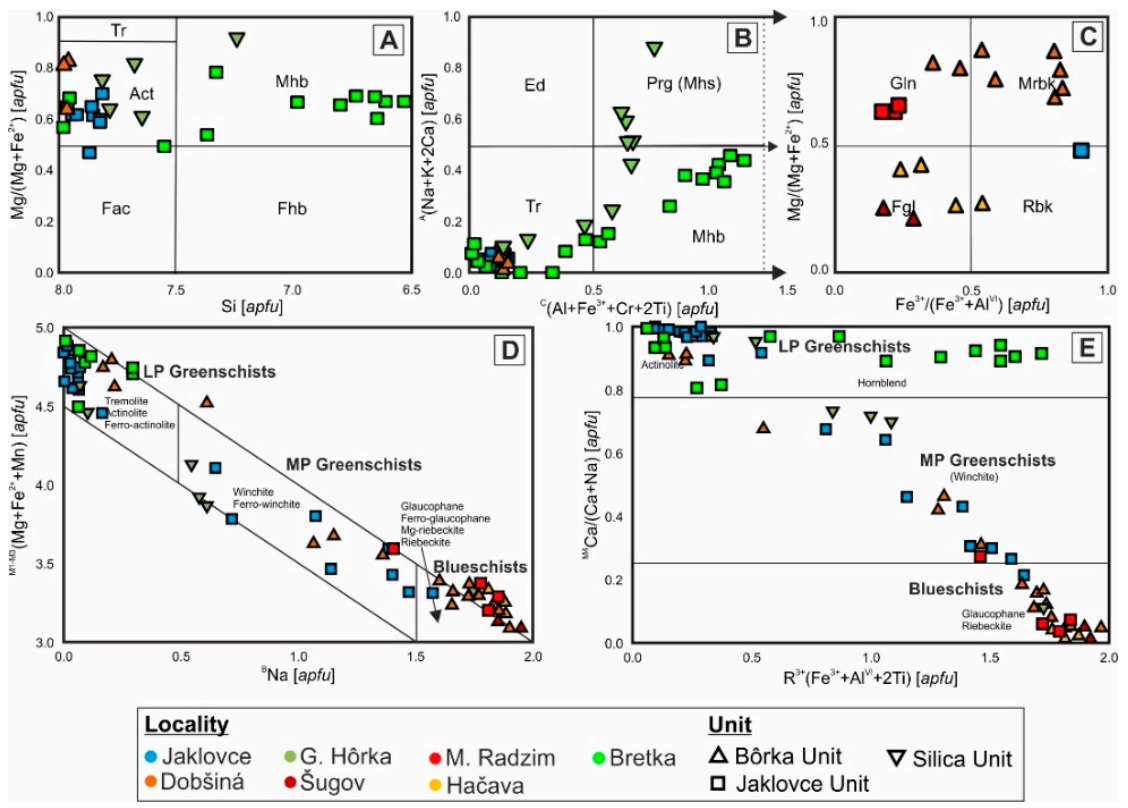

Figure 18. Classification diagrams of amphibole from the Bôrka, Jaklovce and Silica units' metabasites: (A,B) classification diagrams of amphiboles after [111,112]; (C) classification diagrams of sodium amphiboles after [111]; (D) diagram of composition of amphiboles in the Gln/Rbk-Tr/Ac-Ts ternary system; (E) amphibole classification according to ${ }^{\mathrm{M} 4}\left(\mathrm{Ca} /(\mathrm{Ca}+\mathrm{Na})\right.$ vs. $\mathrm{R}^{3+}\left(\mathrm{Fe}^{3+}+\mathrm{Al}^{\mathrm{VI}}+2 \mathrm{Ti}\right)$.

The following contents were noted: the $\mathrm{Na}_{2} \mathrm{O}$ sodium amphibole content ranges from 4.2 to $7.8 \mathrm{wt} . \%$ with the lower values linked to up to $4.9 \mathrm{wt} . \% \mathrm{Fwn}$ in the sample DO-31; the $\mathrm{Al}_{2} \mathrm{O}_{3}$ content varies between 2.2 and $8.1 \mathrm{wt} . \%$ with lower values in Rbk/Mrbk (up to $5.1 \mathrm{wt} . \%$, s. HAC-1, DO-31); Fwn (up to 2.8 wt.\%, s. DO-31); the $\mathrm{MgO}$ varies between 3.0 and $17.4 \mathrm{wt} . \%$ with higher values for Mrbk, Fwn (s. DO-31) and lower for Gln (up to 6.2 wt.\%, s. HAC-1) (Table 3); the FeO content in sodium amphiboles is relatively high in all samples, between 12.8 and $26.8 \mathrm{wt} . \%$. Figure 16A shows that Hačava glaucophane samples have prograde zoning with an increased content of $\mathrm{FeO}$ in the crystal core up to $26.5 \mathrm{wt}$.\% (Table 3), there is up to $7.8 \mathrm{wt} . \% \mathrm{Al}_{2} \mathrm{O}$ and up to $6.2 \mathrm{wt} . \% \mathrm{MgO}$ increase towards the crystal rim. Amphiboles with an Act composition were identified in samples from Dobšiná (s. DO-31, Table 3) with a CaO content up to $12.4 \mathrm{wt} . \%$ and generally low content of $\mathrm{Al}_{2} \mathrm{O}_{3}$ and $\mathrm{Na}_{2} \mathrm{O}$ content up to 0.80 wt.\%. Finally, $\mathrm{FeO}$ in Act approaches $8.2 \mathrm{wt} . \%$ (Table 3).

Figure 18D,E then highlights that the Jaklovce Unit samples (Figure 17B-F) amphibole composition creates a similar trend parallel to the Tr-Gln joint. In addition, the amphiboles chemical analysis mainly plots into the Act (Tr) and Wnc fields (Figure 18A,B,D,E). The glaucophane occurs only in sample MR-1 from Malý Radzim at Brdárka. The $\mathrm{Na}_{2} \mathrm{O}$ concentration in the sodium amphiboles reaches $8.0 \mathrm{wt} . \%$. Glaucophane has increased $\mathrm{Al}_{2} \mathrm{O}_{3}$ up to $8.7 \mathrm{wt} . \%$, and this contrasts with the rest of the sample's lower value up to 2.65 wt.\% (Figures 17B and 18C-E; Table 3). 
Table 3. Representative analyses of amphibole from the Bôrka, Jaklovce and Silica units.

\begin{tabular}{|c|c|c|c|c|c|c|c|c|c|c|c|c|c|c|c|c|c|c|c|}
\hline Sample: & HAC-1 & HAC-1 & HAC-1 & SUG-10 & DO-31 & DO-31 & DO-31 & DO-31 & JAK-30 & $\mathrm{J}-7 \mathrm{~A}$ & $J-6$ & $J-6$ & MR-1 & BRT-1 & BRT-1 & SA-6 & SA-6 & SA-6 & SA-6 \\
\hline Mineral & $\mathrm{Gln}(\mathrm{c})$ & $G \ln (r)$ & Rbk & Gln & Gln & Mrbk & Fwn & Act & Act & Rbk & Fwn & Act & Gln & Mhb & Act & Mrbk & Act & Mhs & Mhb \\
\hline An. N.: & 10 & 11 & 9 & 1 & 1 & 2 & 3 & 4 & 1 & 5 & 3 & 1 & 1 & 10 & 11 & 2 & 5 & 8 & 10 \\
\hline Tectonic U.: & \multicolumn{8}{|c|}{ Bôrka Unit } & \multicolumn{3}{|l|}{$\begin{array}{l}\text { Jaklovce } \\
\text { U. }\end{array}$} & \multicolumn{5}{|c|}{ Jaklovce Unit } & \multicolumn{3}{|c|}{ Silica Unit } \\
\hline $\mathrm{SiO}_{2}$ & 54.90 & 56.54 & 54.56 & 54.02 & 59.02 & 57.39 & 56.14 & 55.25 & 53.39 & 54.39 & 54.55 & 53.66 & 57.58 & 49.20 & 54.64 & 56.04 & 54.58 & 43.51 & 51.15 \\
\hline $\mathrm{TiO}_{2}$ & 0.00 & 0.02 & 0.00 & 0.02 & 0.09 & 0.04 & 0.00 & 0.05 & 0.00 & 0.00 & 0.05 & 0.00 & 0.02 & 0.09 & 0.00 & 0.02 & 0.14 & 2.05 & 0.33 \\
\hline $\mathrm{Al}_{2} \mathrm{O}_{3}$ & 5.88 & 7.83 & 4.79 & 8.08 & 5.57 & 2.18 & 2.33 & 0.47 & 1.43 & 0.83 & 1.58 & 0.57 & 8.58 & 4.93 & 0.14 & 3.15 & 1.24 & 9.09 & 4.94 \\
\hline $\mathrm{Cr}_{2} \mathrm{O}_{3}$ & 0.00 & 0.00 & 0.00 & 0.00 & 0.00 & 0.00 & 0.00 & 0.00 & 0.00 & 0.00 & 0.02 & 0.02 & 0.01 & 0.00 & 0.00 & 0.00 & 0.02 & 0.00 & 0.03 \\
\hline $\mathrm{FeO}$ & 26.12 & 20.14 & 26.80 & 24.49 & 12.76 & 15.22 & 12.36 & 14.35 & 12.04 & 25.79 & 13.61 & 24.20 & 13.48 & 18.61 & 14.05 & 20.50 & 10.61 & 15.27 & 9.34 \\
\hline $\mathrm{MnO}$ & 0.50 & 0.06 & 0.53 & 0.13 & 0.02 & 0.12 & 0.10 & 0.32 & 0.19 & 0.28 & 0.24 & 0.51 & 0.12 & 0.26 & 0.24 & 0.16 & 0.28 & 0.22 & 0.28 \\
\hline $\mathrm{MgO}$ & 3.72 & 6.11 & 3.94 & 2.98 & 13.18 & 14.11 & 16.01 & 14.81 & 15.80 & 7.50 & 14.78 & 8.22 & 10.01 & 10.87 & 14.90 & 9.65 & 17.20 & 12.79 & 19.01 \\
\hline $\mathrm{NiO}$ & 0.00 & 0.00 & 0.00 & 0.04 & 0.00 & 0.01 & 0.02 & 0.04 & 0.00 & 0.00 & 0.05 & 0.00 & 0.00 & 0.00 & 0.00 & 0.00 & 0.00 & 0.00 & 0.00 \\
\hline $\mathrm{CaO}$ & 0.23 & 0.53 & 0.21 & 0.67 & 1.43 & 2.51 & 6.25 & 11.57 & 12.51 & 2.68 & 12.74 & 5.42 & 0.65 & 12.25 & 13.04 & 1.32 & 12.59 & 10.75 & 9.59 \\
\hline $\mathrm{Na}_{2} \mathrm{O}$ & 6.59 & 6.42 & 6.58 & 6.50 & 6.58 & 5.98 & 4.18 & 0.96 & 0.35 & 5.72 & 0.28 & 4.54 & 6.84 & 0.41 & 0.01 & 6.29 & 0.49 & 3.37 & 2.62 \\
\hline $\mathrm{K}_{2} \mathrm{O}$ & 0.00 & 0.02 & 0.00 & 0.03 & 0.04 & 0.04 & 0.10 & 0.07 & 0.00 & 0.03 & 0.03 & 0.03 & 0.01 & 0.12 & 0.00 & 0.00 & 0.02 & 0.25 & 0.12 \\
\hline $\mathrm{Cl}$ & 0.00 & 0.00 & 0.00 & 0.02 & 0.00 & 0.05 & 0.00 & 0.00 & 0.00 & 0.00 & 0.00 & 0.00 & 0.01 & 0.00 & 0.01 & 0.00 & 0.04 & 0.14 & 0.07 \\
\hline Total & 97.94 & 97.68 & 97.41 & 96.97 & 98.69 & 97.64 & 97.49 & 97.89 & 95.79 & 97.25 & 97.93 & 97.17 & 97.32 & 96.82 & 97.06 & 97.12 & 97.19 & 97.39 & 97.45 \\
\hline $\mathrm{Si}^{4+}$ & 8.000 & 8.000 & 8.000 & 7.948 & 8.000 & 7.96 & 7.913 & 7.972 & 7.816 & 8.000 & 7.862 & 7.993 & 7.999 & 7.352 & 7.969 & 8.000 & 7.818 & 6.505 & 7.225 \\
\hline $\mathrm{Ti}^{4+}$ & 0.000 & 0.002 & 0.000 & 0.003 & 0.009 & 0.004 & 0.000 & 0.005 & 0.000 & 0.000 & 0.005 & 0.000 & 0.002 & 0.010 & 0.000 & 0.002 & 0.015 & 0.231 & 0.035 \\
\hline $\mathrm{Al}^{3+}$ & 1.012 & 1.321 & 0.831 & 1.402 & 0.893 & 0.356 & 0.387 & 0.08 & 0.246 & 0.144 & 0.268 & 0.100 & 1.405 & 0.869 & 0.023 & 0.530 & 0.210 & 1.601 & 0.824 \\
\hline $\mathrm{Cr}^{3+}$ & 0.000 & 0.000 & 0.000 & 0.000 & 0.000 & 0.000 & 0.000 & 0.000 & 0.000 & 0.000 & 0.002 & 0.002 & 0.001 & 0.000 & 0.000 & 0.000 & 0.002 & 0.000 & 0.003 \\
\hline $\mathrm{Fe}^{3+}$ & 0.814 & 0.271 & 0.986 & 0.547 & 0.761 & 1.316 & 0.469 & 0.067 & 0.06 & 1.366 & 0.000 & 0.864 & 0.432 & 0.300 & 0.000 & 1.203 & 0.077 & 0.214 & 0.561 \\
\hline $\mathrm{Fe}^{2+}$ & 2.378 & 2.14 & 2.313 & 2.466 & 0.69 & 0.45 & 0.988 & 1.665 & 1.414 & 1.807 & 1.640 & 2.150 & 1.134 & 2.026 & 1.714 & 1.246 & 1.194 & 1.694 & 0.542 \\
\hline $\mathrm{Mg}^{2+}$ & 0.81 & 1.303 & 0.864 & 0.653 & 2.673 & 2.918 & 3.364 & 3.186 & 3.448 & 1.645 & 3.175 & 1.825 & 2.073 & 2.421 & 3.240 & 2.054 & 3.673 & 2.850 & 4.002 \\
\hline $\mathrm{Mn}^{2+}$ & 0.062 & 0.008 & 0.067 & 0.016 & 0.002 & 0.014 & 0.012 & 0.039 & 0.023 & 0.035 & 0.029 & 0.064 & 0.014 & 0.033 & 0.03 & 0.019 & 0.034 & 0.027 & 0.033 \\
\hline $\mathrm{Ca}^{2+}$ & 0.036 & 0.082 & 0.033 & 0.106 & 0.208 & 0.373 & 0.944 & 1.789 & 1.962 & 0.422 & 1.967 & 0.865 & 0.097 & 1.96 & 2.037 & 0.202 & 1.932 & 1.722 & 1.451 \\
\hline $\mathrm{Ni}^{2+}$ & 0.000 & 0.000 & 0.000 & 0.004 & 0.003 & 0.002 & 0.000 & 0.000 & 0.006 & 0.000 & 0.006 & 0.000 & 0.000 & 0.000 & 0.000 & 0.000 & 0.000 & 0.000 & 0.000 \\
\hline $\mathrm{Na}^{+}$ & 1.867 & 1.783 & 1.877 & 1.855 & 1.735 & 1.608 & 1.142 & 0.268 & 0.099 & 1.632 & 0.078 & 1.311 & 1.843 & 0.117 & 0.004 & 1.742 & 0.135 & 0.976 & 0.716 \\
\hline $\mathrm{K}^{+}$ & 0.000 & 0.004 & 0.001 & 0.005 & 0.007 & 0.007 & 0.018 & 0.013 & 0.001 & 0.006 & 0.006 & 0.006 & 0.002 & 0.023 & 0.000 & 0.000 & 0.003 & 0.048 & 0.021 \\
\hline Total & 15.00 & 15.00 & 15.00 & 15.00 & 15.01 & 15.01 & 15.24 & 15.09 & 15.08 & 15.06 & 14.97 & 15.12 & 15.31 & 15.49 & 15.13 & 15.00 & 15.05 & 15.22 & 15.03 \\
\hline $\mathrm{Cl}^{-}$ & 0.00 & 0.00 & 0.00 & 0.01 & 0.00 & 0.01 & 0.00 & 0.00 & 0.00 & 0.00 & 0.00 & 0.00 & 0.00 & 0.00 & 0.00 & 0.01 & 0.04 & 0.00 & 0.03 \\
\hline $\mathrm{OH}^{-}$ & 2.00 & 2.00 & 2.00 & 1.99 & 2.00 & 1.99 & 2.00 & 2.00 & 2.00 & 2.00 & 2.00 & 2.00 & 2.00 & 2.00 & 2.00 & 2.00 & 1.99 & 1.96 & 1.98 \\
\hline $\mathrm{Fe}^{2+} /\left(\mathrm{Fe}^{2+}+\mathrm{Mg}\right)$ & 0.75 & 0.62 & 0.73 & 0.79 & 0.21 & 0.13 & 0.23 & 0.34 & 0.30 & 0.52 & 0.34 & 0.54 & 0.35 & 0.46 & 0.35 & 0.38 & 0.25 & 0.37 & 0.12 \\
\hline
\end{tabular}

Amphibole analyses calculations are based on 15 cations. 
Amphiboles with Act and Wnc composition occur in greenschist facies metabasites (s. J-6,7A, Figure 17C,D; s. BRT-5) and in the greenschist overprint minerals assemblage of Bretka metabasalts (s. BRT-1, BRT-2, Figure 17E,F). Almost all Wnc and Act amphiboles have an increased content of $\mathrm{FeO}$ up to $26 \mathrm{wt}$ \% , and the Act $\mathrm{CaO}$ reaches $12.7 \mathrm{wt}$ \% (Table 3). Analyses that plot into the Mhb field (Figure 18B) belong to an amphibolite facies mineral assemblage of Bretka metabasalts (s. BRT-1, BRT-2, Figure 17E,F). Here, the $\mathrm{Al}_{2} \mathrm{O}$ ranges up to $10.5 \mathrm{wt}$ \% while the $\mathrm{TiO}_{2}$ content is relatively low, at up to $0.5 \mathrm{wt} . \%$.

The amphibole composition in the Silica Unit samples is very variable. Analyses which plot along the entire Tr-Gln joint in Figure 18D,E mirror the transition from sodium-rich Mrbk composition to Ca-rich Act amphiboles. The $\mathrm{Na}_{2} \mathrm{O}$ content in sodium amphiboles reaches 6.3 wt.\% (Table 3). In addition, the Silica Unit metagabbro contains magmatic Mhs relics with $\mathrm{Al}_{2} \mathrm{O}$ up to 9.1 wt.\% and $\mathrm{TiO}_{2}$ to $2.1 \mathrm{wt} \%$ Mhs to Mhb transition towards the crystal rim is accompanied by decreased $\mathrm{Al}_{2} \mathrm{O}_{3}$ up to 4.9 wt.\% and $\mathrm{TiO}_{2}$ to 0.3 wt.\% (Figure 18A,B and Figure 19A,B, Table 3).
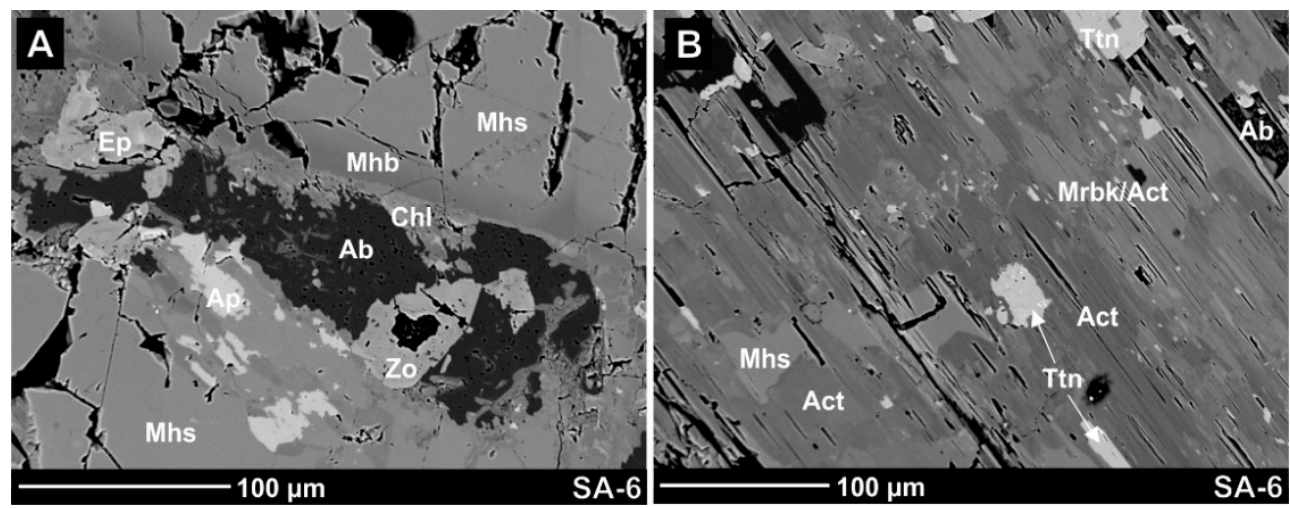

Figure 19. Metagabbro in the Silica Nappe Permian salinar mélange at Gemerská Hôrka (s. SA-6). $(\mathbf{A}, \mathbf{B})$ relics of the magmatic Mhs to Mhb and Pl. Newly formed Mrbk, Act and Chl partly replace magmatic amphiboles and coexist with other LT metamorphic phases such as Act, Ab, Ep, Zo and Ttn.

\subsubsection{White Mica}

Celadonite-rich $\mathrm{Ms}(\mathrm{Ph})$ is typical HP white mica in the Bôrka Unit blueschists and marbles (Figure 15A,B and Figure 17A; Table 4). It is closely associated with the Gln and Grt of the D1 peak metamorphic assemblage. White mica from metabasites has $\mathrm{SiO}_{2}$ content from 49.2 to $53.4 \mathrm{wt}$.\% (3.26-3.64 a.p.f.u). The marble $\mathrm{SiO}_{2}$ content reaches 47.2 wt.\% (3.3 a.p.f.u.) and the $\mathrm{K}_{2} \mathrm{O}$ values in mica vary between 8.2 and 11.1 wt.\%; with the lowest values bound to marbles in sample MEL-11/19. Sample HAC-1 from Hačava exhibits increased FeO content 5.8-6.0 wt.\%, accompanied by a lower $\mathrm{MgO}$ up to $3.1 \mathrm{wt}$ \%. In direct contrast, however, the Dobšiná and Šugov samples generally have lower FeO up to 3.9 wt.\% and higher $\mathrm{MgO}$ up to $5.4 \mathrm{wt}$ \% (Table 4).

$\mathrm{SiO}_{2}$ content in white mica from Jaklovce Unit ranges from 45.0 to 55.7 wt.\% (3.11-3.66 a.p.f.u.) with lower values largely represented in metaradiolarites (Figure 20A-C) up to $50.7 \mathrm{wt}$ \%, except sample DO-K2 (Table 4). The variable $\mathrm{K}_{2} \mathrm{O}$ between 7.8 and $10.8 \mathrm{wt} . \%$ in all metaradiolarite samples documents a transitional illite-phengite composition with a decreased $\mathrm{Na}+\mathrm{K}$ or $\mathrm{K}_{2} \mathrm{O}$. However, contents up to 5.3 wt. $\% \mathrm{MgO}$ and 6.2 wt.\% FeO are relatively constant in all samples. 
Table 4. Representative analyses of white mica from the Bôrka, Jaklovce, Meliata and Silica units.

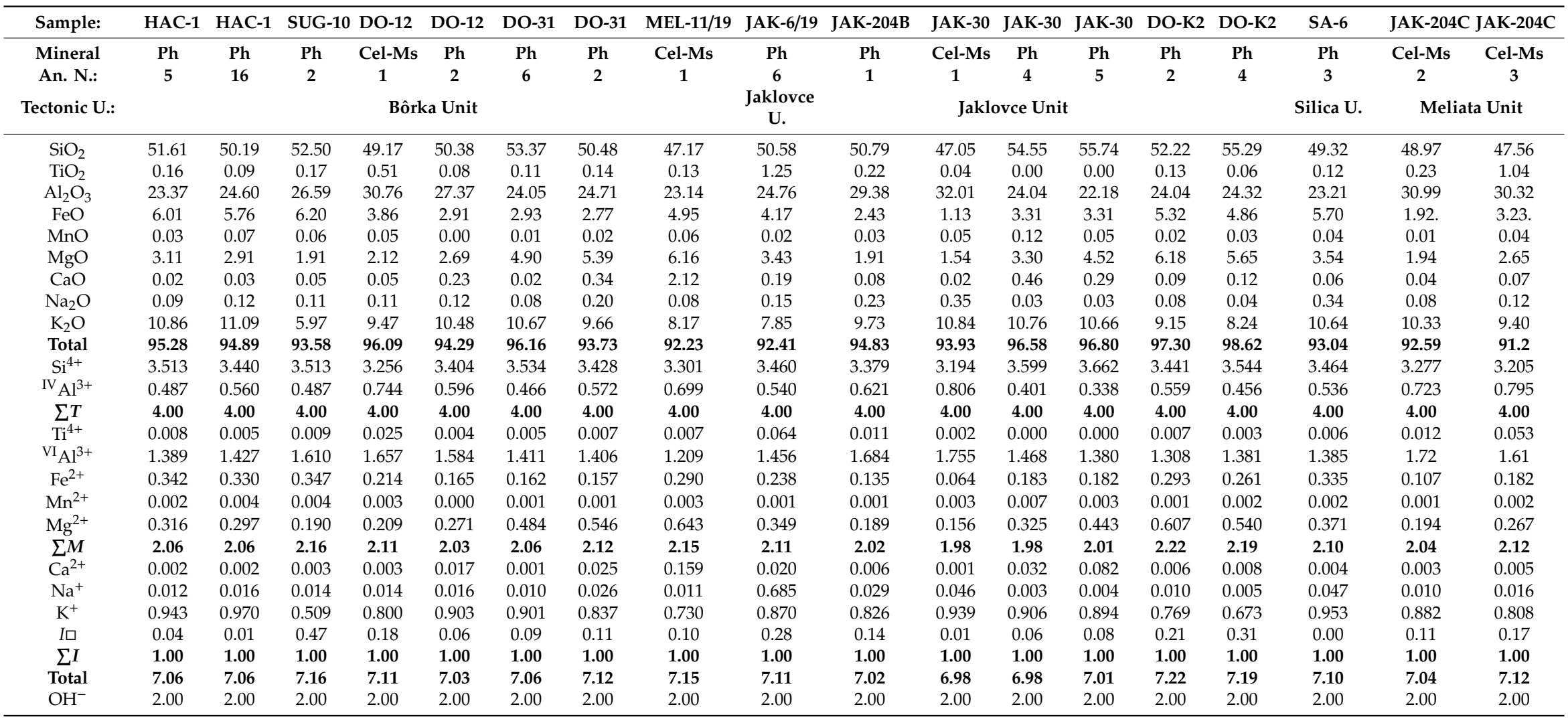

White mica analyses calculations are based on 11 oxygens: $\Sigma T$ —sum of tetrahedral $(T)$ site; $\Sigma M —$ sum of octahedral $(M)$ site; $\Sigma I —$ sum of interlayer cations; $\square$ —vacancy. 

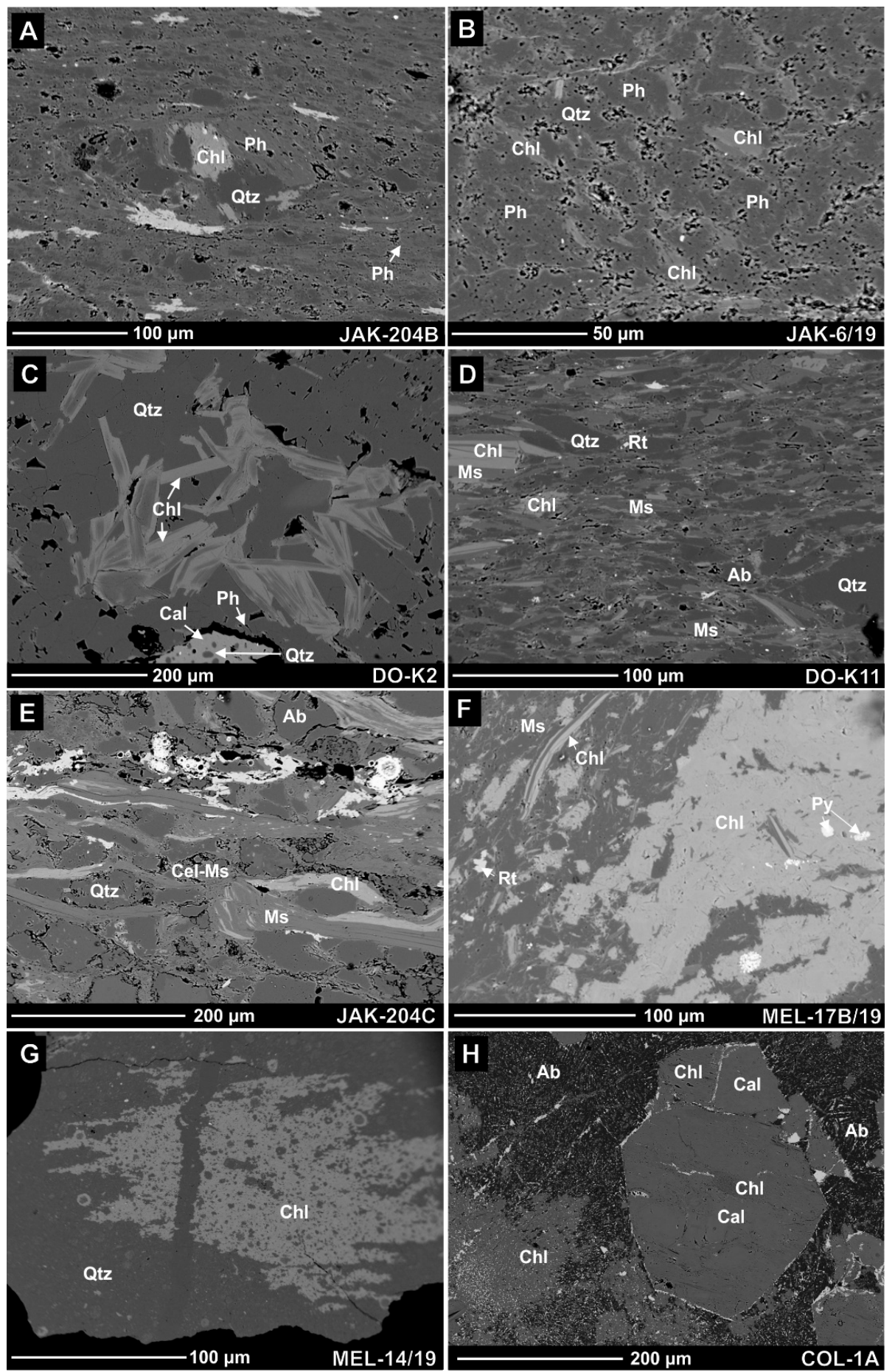

Figure 20. BSE images from the Jaklovce Unit metaradiolarites (A-C), Meliata Unit flysch (D-F) and radiolarite (G) and Čoltovo metabasalt (H): (A-C) Ph-Chl metaradiolarite associated with Jaklovce Unit metabasalts; (D) sandy layer in siliciclastic flysch composed of clastogenic Ms, Chl and Qtz and newly formed $\mathrm{Ab}$ in the Končistá area south of Dobšiná; (E) sandy layer in the siliciclastic flysch composed of clastogenic Ms and Qtz and newly formed Chl, Cel-Ms and Ab at Jaklovce; (F) contact of dark red radiolarite layer with siliciclastic flysch at Meliata. Porphyroclasts of Ms (to illite-phengite) and Chl are bent in a cherty matrix overgrown by newly formed Chl porphyroblast; (G) dark metaradiolarite layer in cherty flysch with newly formed Chl porphyroblast at Meliata; (H) Coltovo metabasalt with porphyric $\mathrm{Cpx}$ replaced by $\mathrm{Chl}$ and $\mathrm{Cal}$. Plagioclase is $\mathrm{Ab}$. 
The clastogenic Ms prevails in most samples from the Meliata Unit calciclastic or siliciclastic flysch (Figure 20D-F) and is often overgrown by newly formed Chl (Figure 20F). Sample JAK-204C contains newly formed Cel-Ms aggregates beside clastogenic Ms (Figure 20E). $\mathrm{K}_{2} \mathrm{O}$ content in newly formed celadonic (phengitic) Ms in the JAK-204C sample ranges from 9.4 to $10.3 \mathrm{wt}$ \%. and the $\mathrm{SiO}_{2}$ is 47.6 to 49.0 wt.\% (3.28-3.30 a.p.f.u) (Table 4). Meliata Unit metaradiolarite and Čoltovo metabasalt contained just newly formed Chl without Cel-Ms (Figure 20G,H).

Chemical analyses of the white mica in both Bôrka and Jaklovce units rocks project along the muscovite-celadonite mixing-line in classification diagram [113] (Figure 21).

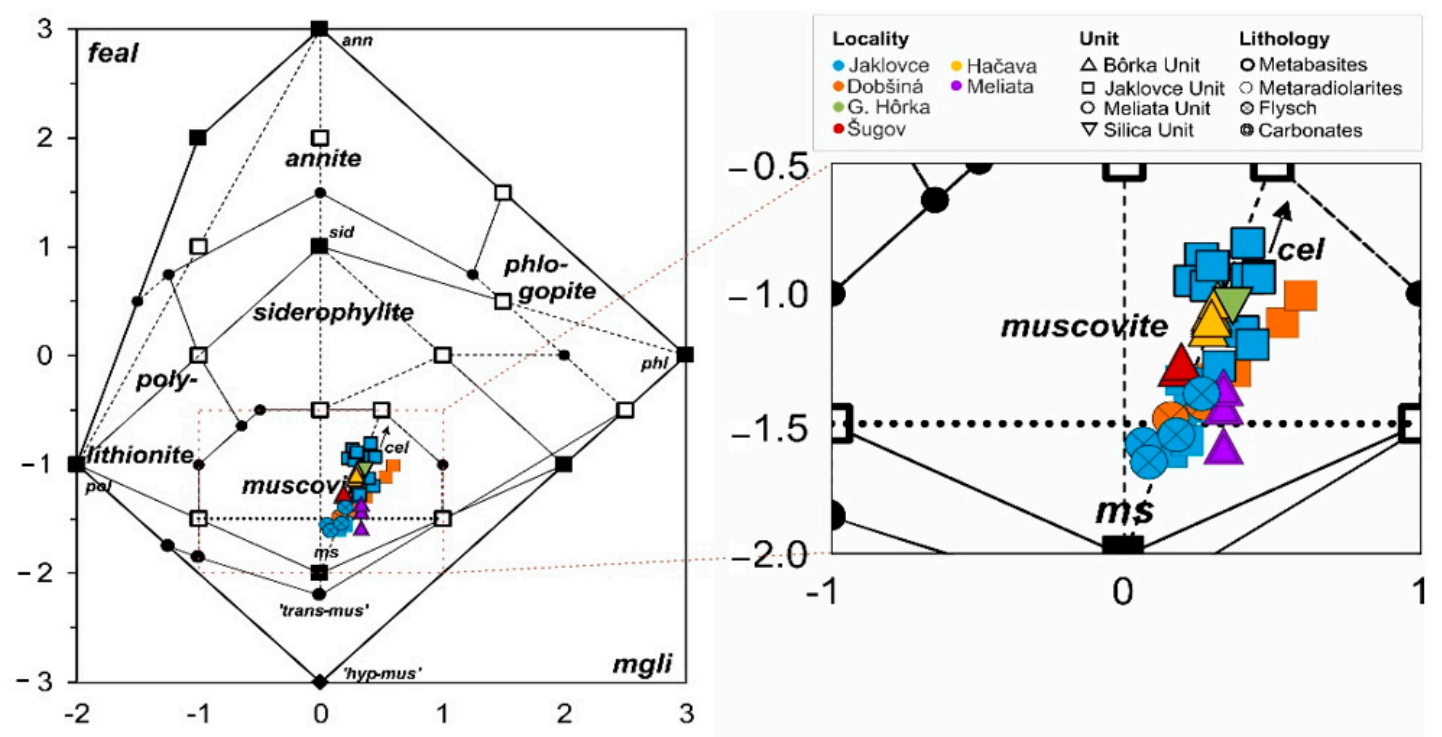

Figure 21. Classification diagram of white mica from the Bôrka, Jaklovce, Meliata and Silica units as in [113]. Parameters represent: $m g l i=\mathrm{Mg}-\mathrm{Li}$, feal $=\left(\mathrm{Fe}^{2+}+\mathrm{Fe}^{3+}+\mathrm{Mn}+\mathrm{Ti}\right)-\mathrm{VI}^{\mathrm{Al}^{3+}}$.

Some Ms porphyroclasts exhibit a transitional illite-phengite composition with decreased $\mathrm{Na}_{2} \mathrm{O}$ at 1.0-0.04 wt.\% and $\mathrm{K}_{2} \mathrm{O}$ at 11.2-7.85 wt.\% (Figure 20B,C,E and Figure 22A; Table 4).
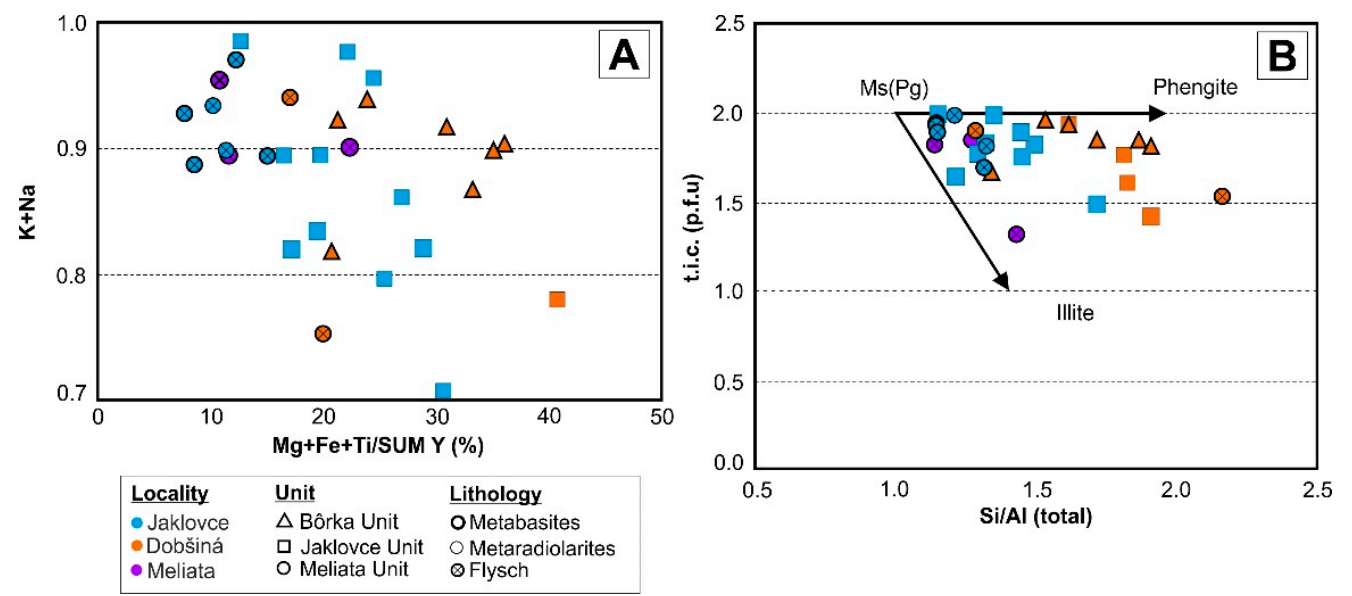

Figure 22. (A) K + Na vs. Mg + Fe + Ti/SUM Y (\%) compositional trend of white mica from Jaklovce and Meliata units metasediments and Bretka Unit metabasites: (B) Ms-Ill-Ph alteration diagram after [54] (Table 4); compositional parameter t.i.c. = total interlayer charge of $\mathrm{K}+\mathrm{Na}+2 \mathrm{Ca}$ (in a.p.f.u.) as in [114].

Analyses of the phengitic white mica in Figure 22B mainly plots along the muscovite-phengite line but they are shifted in semi-parallel to the illite field. This is due to the small but significant deficit in interchange layer [114]. The total interlayer charge (t.i.c.) calculated for 22 oxygens is approximately 1.7 a.p.f.u. 
White mica in the Gemerská Hôrka metagabbro (Figure 19A,B) shows celadonic (phengitic) composition (Figure 21) with $\mathrm{K}_{2} \mathrm{O}$ values up to $10.6 \mathrm{wt} . \%$ and $\mathrm{SiO}_{2}$ up to $49.3 \mathrm{wt} . \%$ (Table 4 ).

\subsubsection{Chlorite}

Chlorite from Bôrka Unit metabasites in Figure 23 and Table 5 mostly belong to the post-peak (D2) mineral association. The chlorite replaces Gln or Grt in some places and occurs in mineral assemblage with $\mathrm{Ab}$, Act, Ep and Bt.

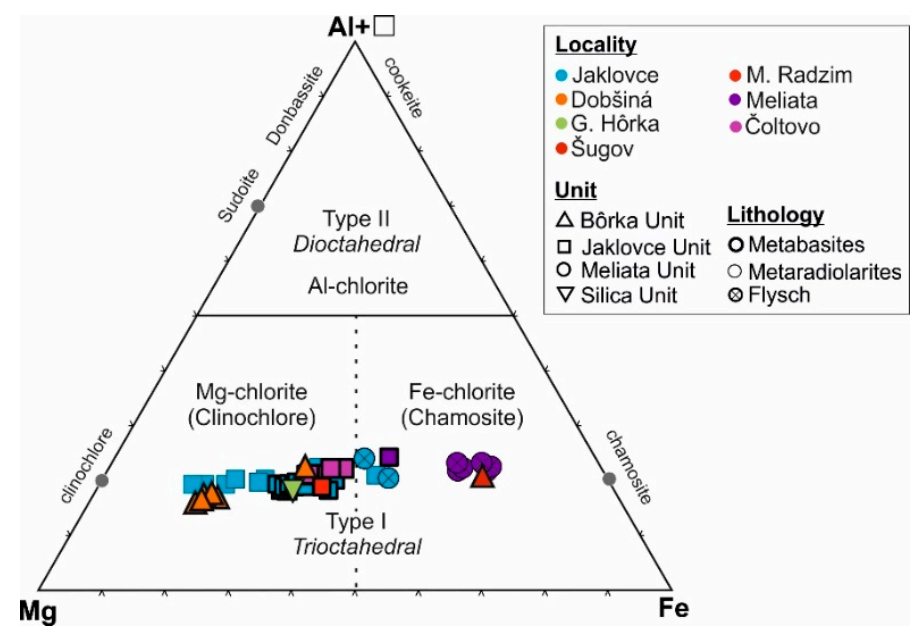

Figure 23. $\mathrm{Al}+\square-\mathrm{Mg}-\mathrm{Fe}$ classification diagram of chlorite from the Bôrka, Jaklovce, Meliata and Silica units after [115].

Chlorites from the metabasite samples were plotted into fields of $\mathrm{Mg}$ and $\mathrm{Fe}$-chlorites in classification diagram of [115] (Figure 23). Fe-chlorite (chamosite) was found in the Šugov blueschist sample SUG-10 with up to $36.8 \mathrm{wt} . \% \mathrm{FeO}$ and $7.0 \mathrm{wt} . \% \mathrm{MgO}$. The $\mathrm{Fe} /(\mathrm{Fe}+\mathrm{Mg}$ ) ratio is 0.74 (Table 5). All chlorites from the Dobšiná blueschist were plotted into the $\mathrm{Mg}-\mathrm{Chl}$ (clinochlore) field with most values between 24.9 and $25.1 \mathrm{wt} . \% \mathrm{MgO}$ and 13.3-14.0 wt.\% FeO as in sample DO-31. The Fe/(Fe $+\mathrm{Mg})$ ratio for Dobšiná samples varies between 0.22 and 0.40. A content of ${ }^{\mathrm{VI}} \mathrm{Al}$ reaches up to 1.08-1.36 a.p.f.u. in all the studied samples from the Bôrka Unit (Table 5).

Figure 23 shows that most of the Jaklovce Unit Chl projects into $\mathrm{Mg}-\mathrm{Chl}$ fields in the classification diagram [115]. Exceptions to this are seen in the MEL-15 metabasalt from Meliata and the JAK-204B metaradiolarite samples. These plot into the $\mathrm{Fe}-\mathrm{Chl}$ chamosite field (Figure 23). MgO content in Chl ranges from 12.7 to $21.9 \mathrm{wt} . \%$ with higher $\mathrm{MgO}$ values generally found in metabasites (Table 5). The $\mathrm{FeO}$ content varies between 17.3 and $27.3 \mathrm{wt} . \%$ with a $\mathrm{FeO} /(\mathrm{FeO}+\mathrm{MgO})$ ratio between 0.31 and 0.54. Finally, the ${ }^{\mathrm{VI}} \mathrm{Al}$ reaches up to 1.13-1.46 a.p.f.u. in all Jaklovce Unit studied samples (Table 5).

All Meliata Unit flysch chlorites plot in the Fe-Chl chamosite field in the classification diagram [115] (Figure 23). The $\mathrm{FeO}$ reaches $25.3-37.3 \mathrm{wt} . \%$ and $\mathrm{MgO}$ 6.3-13.9 wt.\%. The $\mathrm{Fe} /(\mathrm{Fe}+\mathrm{Mg}$ ) ratio is $0.51-0.78$, and the ${ }^{\mathrm{VI}} \mathrm{Al}$ content varies between 1.3 and 1.49 a.p.f.u. (Table 5).

Chlorite in Gemerská Hôrka metagabbro (Figure 19A,B) plots in the Mg-Chl (clinochlore) field (Figure 23). The $\mathrm{Fe} /\left(\mathrm{Fe}+\mathrm{Mg}\right.$ ) ratio is 0.38 and the $\mathrm{Al}^{\mathrm{VI}}$ value is 1.09 a.p.f.u. (Table 5). 
Table 5. Representative analyses of chlorite from the Bôrka, Jaklovce, Meliata and Silica units.

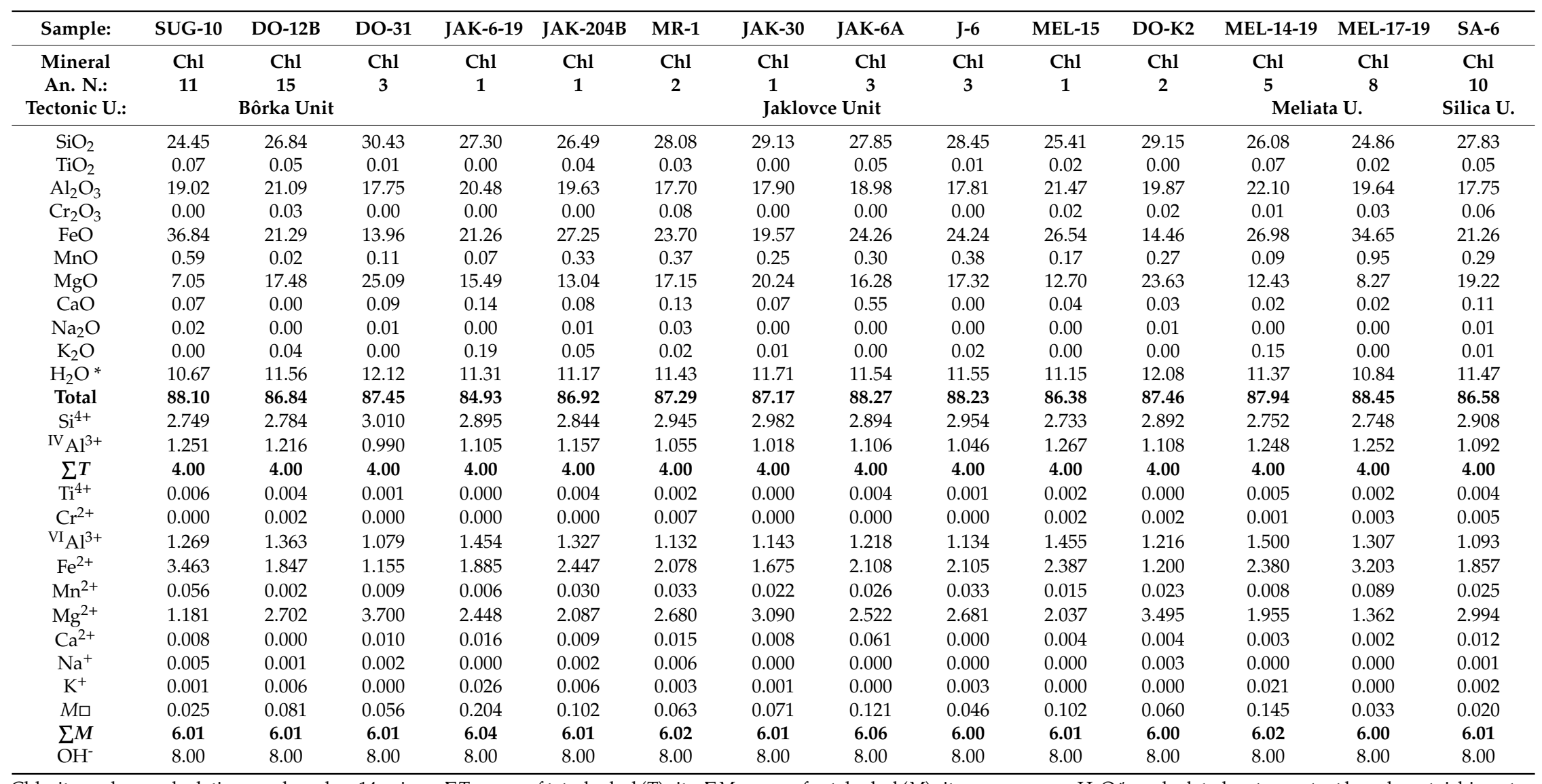

Chlorite analyses calculations are based on 14 anions: $\Sigma T$ —sum of tetrahedral $(T)$ site; $\Sigma M$ —sum of octahedral $(M)$ site; $\square$ —vacancy; $\mathrm{H}_{2} \mathrm{O}^{*}$ —calculated water content based on stoichiometry. 


\subsubsection{Carbonates}

Carbonate rich layers in the Meliata Unit flysh contain Cal intergrown with Dol grains. These form part of the Cal-Dol-Ab-Chl-Kfs-Qtz assemblage of the peak D1 metamorphic stage (Figure 24A-C; Table 6). In addition, tiny Dol grains are ingrown to Cal in the Bôrka Unit marbles due to distinct metamorphic overprinting, while the younger Cal veinlets contain no Dol (Figure 24D; Table 6).
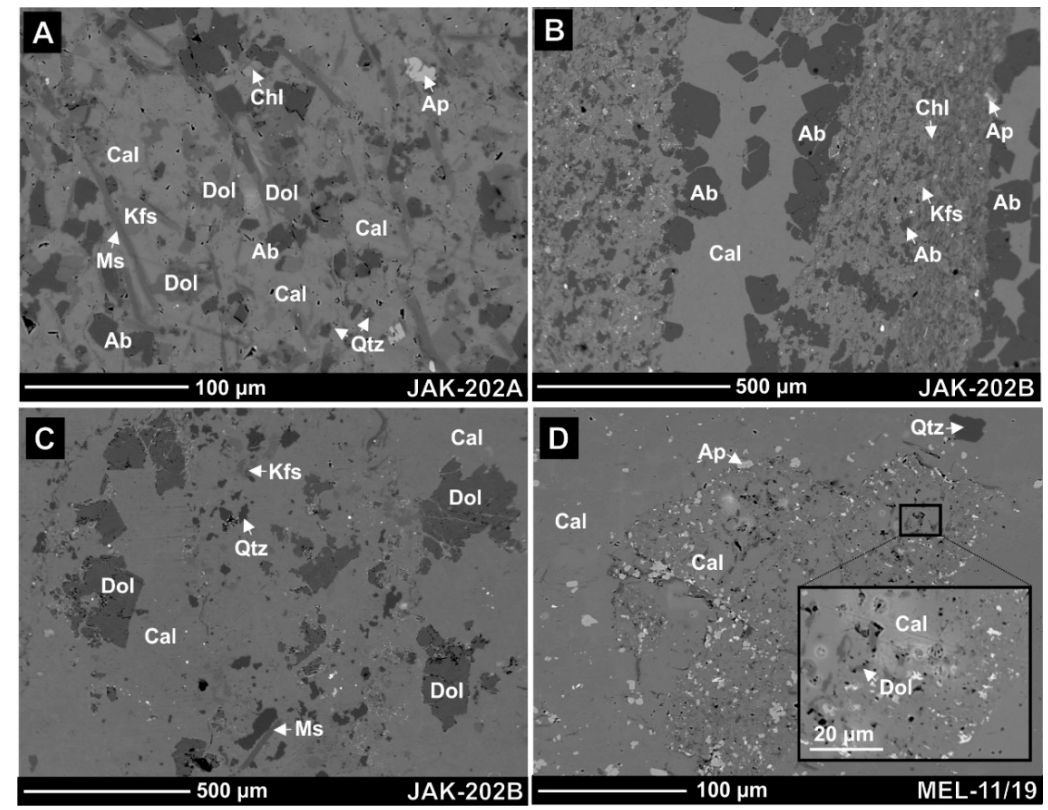

Figure 24. BSE images of carbonate-rich layers in Meliata Unit flysh (A-C) and a marble olistolith from the inferred Bôrka Unit (D); (A-C) Cal-Dol-Ab-Chl-Kfs-Qtz assemblage of the peak (D1) metamorphic stage from the carbonatic layer of calciclastic flysch at Jaklovce; (D) Cal-Dol-Cel-Ms assemblage of the peak (D1) metamorphic stage from a marble mylonite block in flysch at Meliata village. Younger coarse-grained Cal occurs in cross-cutting veinlets seen clearly in the upper left corner.

Table 6. Representative analyses of calcite and dolomite from the Bôrka and Meliata units.

\begin{tabular}{|c|c|c|c|c|c|c|c|c|}
\hline Sample: & MEL-11/19 & MEL-11/19 & JAK-202A & JAK-202A & JAK-202B & JAK-202B & JAK-202B & JAK-202B \\
\hline Mineral & Cal & Dol & Cal & Dol & Cal & Dol & Cal & Dol \\
\hline An. N.: & 2 & 3 & 1 & 2 & 3 & 4 & 26 & 27 \\
\hline Tectonic U.: & \multicolumn{2}{|c|}{ Bôrka Unit } & \multicolumn{6}{|c|}{ Meliata Unit } \\
\hline $\mathrm{MgO}$ & 0.58 & 19.48 & 0.55 & 16.62 & 0.58 & 17.22 & 0.58 & 16.52 \\
\hline $\mathrm{CaO}$ & 55.05 & 32.05 & 54.74 & 31.99 & 53.14 & 33.20 & 53.01 & 31.63 \\
\hline $\mathrm{MnO}$ & 0.64 & 0.44 & 0.21 & 1.64 & 0.11 & 0.33 & 0.16 & 0.70 \\
\hline $\mathrm{FeO}$ & 0.32 & 1.33 & 0.48 & 3.19 & 0.46 & 2.81 & 0.40 & 2.65 \\
\hline $\mathrm{SrO}$ & 0.00 & 0.00 & 0.06 & 0.01 & 0.07 & 0.03 & 0.01 & 0.00 \\
\hline Total & 56.60 & 53.31 & 56.05 & 53.44 & 54.36 & 53.60 & 54.16 & 51.50 \\
\hline $\mathrm{Mg}^{2+}$ & 0.029 & 0.896 & 0.028 & 0.785 & 0.030 & 0.804 & 0.030 & 0.803 \\
\hline $\mathrm{Ca}^{2+}$ & 1.945 & 1.059 & 1.952 & 1.086 & 1.953 & 1.114 & 1.954 & 1.105 \\
\hline $\mathrm{Mn}^{2+}$ & 0.018 & 0.012 & 0.006 & 0.044 & 0.003 & 0.009 & 0.005 & 0.019 \\
\hline $\mathrm{Fe}^{2+}$ & 0.009 & 0.034 & 0.013 & 0.084 & 0.013 & 0.073 & 0.012 & 0.072 \\
\hline $\mathrm{Sr}^{2+}$ & 0.000 & 0.000 & 0.001 & 0.000 & 0.001 & 0.001 & 0.000 & 0.000 \\
\hline C & 2.000 & 2.000 & 2.000 & 2.000 & 2.000 & 2.000 & 2.000 & 2.000 \\
\hline Total & 4.00 & 4.00 & 4.00 & 4.00 & 4.00 & 4.00 & 4.00 & 4.00 \\
\hline$\% \mathrm{MgCO}_{3}$ & 1.44 & 44.77 & 1.38 & 39.26 & 1.48 & 40.18 & 1.49 & 40.17 \\
\hline$\% \mathrm{CaCO}_{3}$ & 97.23 & 52.94 & 97.60 & 54.31 & 97.63 & 55.67 & 97.69 & 55.25 \\
\hline$\% \mathrm{MnCO}_{3}$ & 0.89 & 0.58 & 0.29 & 2.20 & 0.16 & 0.44 & 0.24 & 0.96 \\
\hline$\% \mathrm{FeCO}_{3}$ & 0.44 & 1.71 & 0.67 & 4.22 & 0.66 & 3.67 & 0.58 & 3.62 \\
\hline$\% \mathrm{SrCO}_{3}$ & 0.00 & 0.00 & 0.00 & 0.00 & 0.00 & 0.00 & 0.00 & 0.00 \\
\hline
\end{tabular}

Calcite and dolomite analyses calculations are based on 6 oxygens. 


\subsubsection{Feldspars}

All feldspars in the Bôrka, Jaklovce and Meliata units metabasites correspond to pure Ab with a composition of $\mathrm{Ab}_{99.1-99.8} \mathrm{An}_{0.1-0.6} \mathrm{Or}_{0.1-0.5}$ (Figure 17B-F; Table 7). Plagioclase relics with higher anorthite content are rare. Similarly, metagabbro from Gemerská Hôrka and metabasalts from Meliata and Čoltovo contain pure Ab after magmatic Pl (Figure 19A,B and Figure 20H). Finally, the carbonate-rich layers in Meliata Unit flysch also contain, besides $\mathrm{Ab}$, pure orthoclase alkali feldspar with a composition of $\mathrm{Ab}_{1.5-2.3} \mathrm{An}_{0.5-0.6} \mathrm{Or}_{97.1-98.0}$ (Figure 24A-C; Table 7).

Table 7. Representative analyses of feldspars from the Bôrka, Jaklovce and Meliata units.

\begin{tabular}{|c|c|c|c|c|c|c|c|c|c|c|}
\hline Sample: & SUG-10 & DO-31 & MR-1 & JAK-6A & MEL-15 & BRT-1A & JAK-202A & JAK-202A & JAK-202B & COL-1 \\
\hline Mineral & $\mathbf{A b}$ & $\mathbf{A b}$ & $\mathbf{A b}$ & $\mathbf{A b}$ & $\mathbf{A b}$ & $\mathbf{A b}$ & Or & $\mathbf{A b}$ & Or & $\mathbf{A b}$ \\
\hline An. N.: & 6 & 7 & 5 & 1 & 2 & 4 & 3 & 4 & 3 & 2 \\
\hline Tectonic U.: & \multicolumn{2}{|c|}{ Bôrka Unit } & \multicolumn{4}{|c|}{ Jaklovce Unit } & \multicolumn{4}{|c|}{ Meliata Unit } \\
\hline $\mathrm{SiO}_{2}$ & 68.59 & 67.07 & 68.26 & 68.29 & 67.93 & 68.09 & 64.94 & 68.39 & 64.98 & 68.68 \\
\hline $\mathrm{Al}_{2} \mathrm{O}_{3}$ & 19.08 & 18.45 & 19.35 & 19.32 & 19.44 & 19.75 & 19.64 & 19.43 & 19.72 & 18.99 \\
\hline $\mathrm{FeO}$ & 0.05 & 0.06 & 0.38 & 0.48 & 0.43 & 0.73 & 0.04 & 0.05 & 0.04 & 0.53 \\
\hline $\mathrm{MgO}$ & 0.00 & 0.00 & 0.02 & 0.24 & 0.10 & 0.23 & 0.00 & 0.00 & 0.00 & 0.19 \\
\hline $\mathrm{CaO}$ & 0.02 & 0.01 & 0.31 & 0.31 & 0.20 & 0.11 & 0.13 & 0.12 & 0.10 & 0.12 \\
\hline $\mathrm{SrO}$ & 0.00 & 0.00 & 0.01 & 0.00 & 0.00 & 0.00 & 0.00 & 0.00 & 0.00 & 0.00 \\
\hline $\mathrm{BaO}$ & 0.00 & 0.00 & 0.00 & 0.00 & 0.00 & 0.00 & 0.25 & 0.00 & 0.24 & 0.00 \\
\hline $\mathrm{Na}_{2} \mathrm{O}$ & 11.53 & 11.77 & 11.52 & 11.25 & 11.16 & 11.80 & 0.26 & 11.74 & 0.16 & 11.79 \\
\hline $\mathrm{K}_{2} \mathrm{O}$ & 0.02 & 0.02 & 0.06 & 0.08 & 0.02 & 0.05 & 16.61 & 0.06 & 15.97 & 0.02 \\
\hline Total & 99.30 & 97.38 & 101.01 & 99.97 & 100.29 & 100.79 & 99.73 & 99.19 & 100.23 & 100.32 \\
\hline $\mathrm{Al}$ & 0.988 & 0.976 & 0.977 & 0.996 & 0.987 & 1.013 & 1.104 & 1.015 & 1.083 & 0.976 \\
\hline $\mathrm{Si}$ & 3.012 & 3.010 & 2.923 & 2.987 & 2.927 & 2.962 & 3.098 & 3.031 & 3.027 & 2.996 \\
\hline $\mathrm{Fe}^{3+}$ & 0.002 & 0.002 & 0.012 & 0.016 & 0.014 & 0.024 & 0.002 & 0.002 & 0.002 & 0.017 \\
\hline $\mathrm{Mg}$ & 0.000 & 0.000 & 0.001 & 0.016 & 0.006 & 0.015 & 0.000 & 0.000 & 0.000 & 0.012 \\
\hline $\mathrm{Ca}$ & 0.001 & 0.000 & 0.014 & 0.015 & 0.009 & 0.005 & 0.007 & 0.006 & 0.005 & 0.006 \\
\hline $\mathrm{Sr}$ & 0.000 & 0.000 & 0.000 & 0.000 & 0.000 & 0.000 & 0.000 & 0.000 & 0.000 & 0.000 \\
\hline $\mathrm{Ba}$ & 0.000 & 0.000 & 0.000 & 0.000 & 0.000 & 0.000 & 0.005 & 0.000 & 0.004 & 0.000 \\
\hline $\mathrm{Na}$ & 0.982 & 1.024 & 0.957 & 0.954 & 0.932 & 0.996 & 0.024 & 1.009 & 0.014 & 0.997 \\
\hline $\mathrm{K}$ & 0.001 & 0.001 & 0.003 & 0.005 & 0.001 & 0.003 & 1.011 & 0.003 & 0.949 & 0.001 \\
\hline Total & 4.99 & 5.01 & 4.89 & 4.99 & 4.89 & 5.09 & 5.25 & 5.07 & 5.09 & 5.01 \\
\hline $\mathrm{Ab}$ (mol. \%) & 99.8 & 99.9 & 98.2 & 98.0 & 98.9 & 99.2 & 2.3 & 99.1 & 1.5 & 99.3 \\
\hline An (mol. \%) & 0.1 & 0.0 & 1.5 & 1.5 & 1.0 & 0.5 & 0.6 & 0.6 & 0.5 & 0.1 \\
\hline Or (mol. \%) & 0.1 & 0.1 & 0.3 & 0.5 & 0.1 & 0.3 & 97.1 & 0.3 & 98.0 & 0.6 \\
\hline
\end{tabular}

Feldspars analyses calculations are based on 8 oxygens.

\subsection{PXRD Analysis}

The mineral composition of calciclastic flysch metasediments was studied also with PXRD (Figure 25). The dominant phases include Qtz and feldspars, which are mostly Ab, but some samples also have a small percentage of $\mathrm{Kfs}$ associated with variable $\mathrm{Chl}$ and Ms proportions (Table 8). Samples DO-F1, DO-F2, JAK-202A, JAK-202B, MEL-3/19 and MEL-18/19 contain a significant admixture of carbonates which mainly comprise Cal and small amounts of Dol. In addition, Chl phyllosilicate has a relatively stable content at $11-38 \mathrm{wt} . \%$ and this is also noted in the small $2.2 \mathrm{wt} . \%$. content in the JAK-202A sample. Muscovite has the following variable contents: JAK-202A, MEL-2/19, MEL-13/19 and MEL-18/19 have less than 10 wt.\% and JAK-202B and MEL-3/19 have 28-32 wt.\%. Finally, DO-F1, DO-F2, DO-K11 and MEL-3/19 are the most enriched in Ms with 37-51 wt.\%, while DO-K11 and MEL-2/19 have an indication of another mica phase, probably paragonite. 


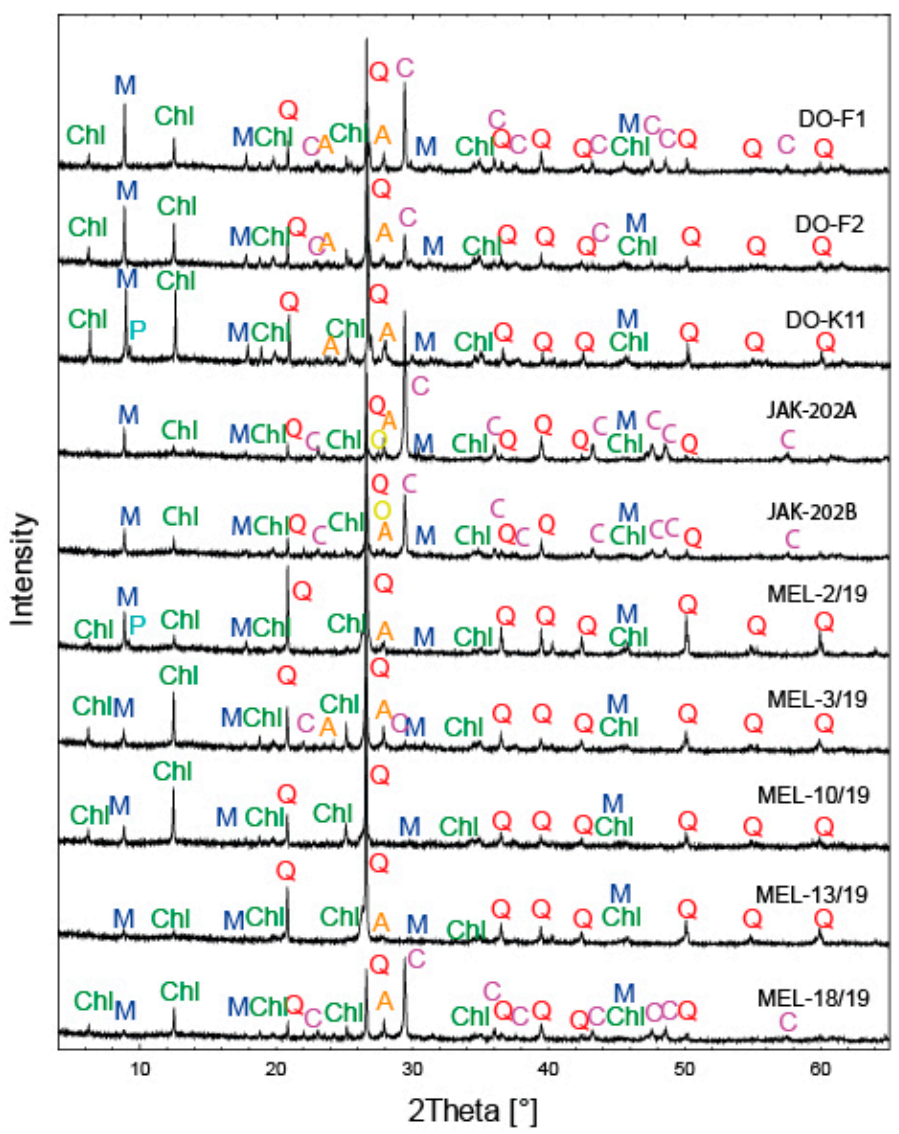

Figure 25. Powder XRD patterns of the Meliata Unit flysch metasediments. The peaks indicate mineral phases in the fine-grained rock matrix.

Table 8. Quantitative proportion of mineral phases calculated from the powder X-ray diffraction (PXRD) data by Rietveld quantitative analysis.

\begin{tabular}{ccccccccccc}
\hline Phase & DO-F1 & DO-F2 & DO-K11 & JAK-202A & JAK-202B & MEL-2/19 & MEL-3/19 & MEL-10/19 & MEL-13/19 & MEL-18/19 \\
\hline Albite & 7.2 & 4.5 & 12.2 & 14.1 & 6.0 & 8.4 & 17.9 & - & 8.3 & 19.1 \\
Calcite & 29.7 & 14.4 & - & 69.4 & 35.9 & - & 2.6 & - & - & 51.4 \\
Chlorite & 12.7 & 18.7 & 23.7 & 2.2 & 11.2 & 26.3 & 15.4 & 38.4 & 32.7 & 15.0 \\
Dolomite & 0.1 & 0.2 & - & 0.2 & - & - & 1.7 & - & - & 0.2 \\
Muscovite & 40.7 & 51.2 & 38.7 & 4.3 & 28.0 & 6.8 & 37.7 & 31.7 & 5.6 & 4.0 \\
K-feldspar & - & - & - & 5.2 & 11.4 & - & - & 5.3 & - & - \\
Paragonite & - & - & 13.2 & - & - & 1.7 & - & - & - & - \\
Quartz & 9.7 & 11.1 & 12.1 & 4.7 & 7.5 & 56.9 & 24.7 & 24.5 & 52.3 & 9.8 \\
\hline
\end{tabular}

\subsection{P-T Estimates}

\subsubsection{Bôrka Unit}

\section{Metabasites}

Perple_X pseudosection modelling determined the precise D1 stage P-T conditions of the Grt-bearing blueschist layers in Hačava marble (Figures 6A and 15A,B). This was accomplished by using whole-rock analysis in Table 9. Figure 26 shows that resultant $\mathrm{P}-\mathrm{T}$ estimates at $520{ }^{\circ} \mathrm{C}$ at $1.55 \mathrm{GPa}$ fit peak D1 metamorphic Grt-Gln-Ph assemblage with a Grt composition of $\mathrm{Alm}_{0.55} \mathrm{Grs}_{0.24} \mathrm{Sps}_{0.21}$ and Si in Ph 3.53 a.p.f.u. (Tables 2, 4 and 10). 
Table 9. Bulk-rock composition of HAC-1 and JAK-30 metabasites in oxide weight and molar percentages.

\begin{tabular}{|c|c|c|c|c|c|c|c|c|c|c|c|c|}
\hline \multicolumn{13}{|c|}{ Weight $\%$ Oxides } \\
\hline Sample & $\mathrm{SiO}_{2}$ & $\mathrm{TiO}_{2}$ & $\mathrm{Al}_{2} \mathrm{O}_{3}$ & $\mathrm{Fe}_{2} \mathrm{O}_{3}$ & $\mathrm{FeO}$ & $\mathrm{MgO}$ & $\mathrm{MnO}$ & $\mathrm{CaO} *$ & $\mathrm{Na}_{2} \mathrm{O}$ & $\mathrm{K}_{2} \mathrm{O}$ & - & - \\
\hline HAC-1 & 49.55 & 2.92 & 13.02 & 1.53 & 12.37 & 4.30 & 0.18 & 2.83 & 3.45 & 4.09 & - & - \\
\hline JAK-30 & 48.70 & 1.41 & 13.20 & 1.01 & 9.05 & 4.88 & - & 10.71 & 5.41 & 0.20 & & \\
\hline JAK-30 * & 47.50 & 1.32 & 13.31 & 1.06 & 9.51 & 9.47 & - & 14.02 & 2.97 & 0.59 & - & - \\
\hline \multicolumn{13}{|c|}{ Molar \% Oxides } \\
\hline Sample & $\mathrm{SiO}_{2}$ & $\mathrm{Al}_{2} \mathrm{O}_{3}$ & $\mathrm{CaO}$ & MgO & $\mathrm{FeO}$ & $\mathrm{MnO}$ & $\mathrm{K}_{2} \mathrm{O}$ & $\mathrm{Na}_{2} \mathrm{O}$ & $\mathrm{TiO}_{2}$ & $\mathrm{O}_{2}$ & $\mathrm{H}_{2} \mathrm{O}$ & $\mathrm{CO}_{2}$ \\
\hline HAC-1 & 56.93 & 8.82 & 3.48 & 7.36 & 13.21 & 0.18 & 3.00 & 3.84 & 2.52 & 0.66 & Excess & - \\
\hline JAK-30 & 52.07 & 8.71 & 9.18 & 15.08 & 9.61 & - & 0.50 & 3.08 & 1.28 & 0.48 & Excess & Excess \\
\hline
\end{tabular}

The $\mathrm{Fe}_{2} \mathrm{O}_{3}$ contents were calculated assuming bulk-rock $\mathrm{Fe}_{2} \mathrm{O}_{3} /\left(\mathrm{FeO}+\mathrm{Fe}_{2} \mathrm{O}_{3}\right)=0.1$. ${ }^{*} \mathrm{CaO}$ was reduced according to bulk-rock phosphorous content and assuming that these elements are bound exclusively to ideally composed Ap. JAK-30. * — calculated bulk composition for metamorphic veinlets.

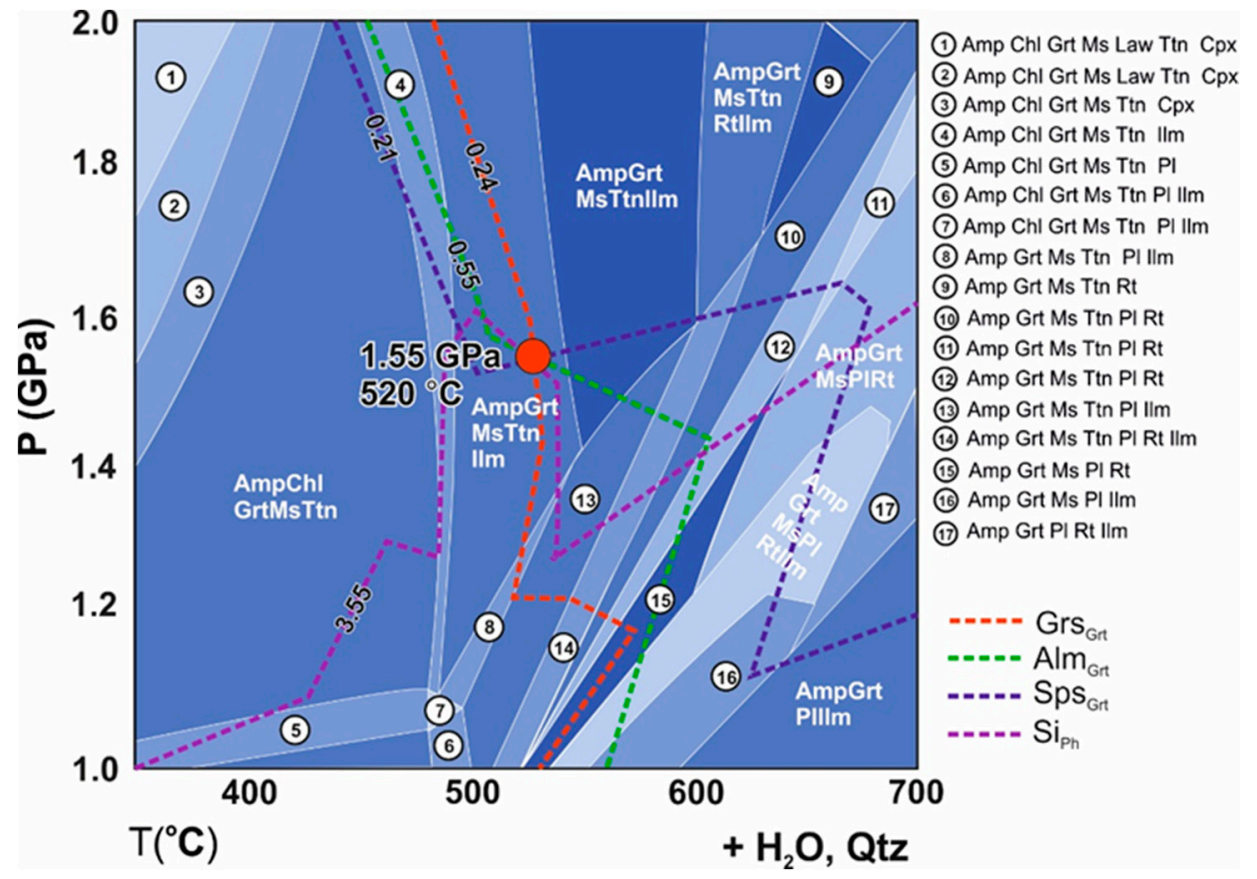

Figure 26. $\mathrm{P}-\mathrm{T}$ pseudosection calculated for the $\mathrm{D} 1$ peak metamorphic stage of Hačava blueschists using a modified composition of an HAC-1 sample (Table 9) in the $\mathrm{MnO}-\mathrm{Na}_{2} \mathrm{O}-\mathrm{CaO}-\mathrm{K}_{2} \mathrm{O}-\mathrm{FeO}-\mathrm{MgO}-$ $\mathrm{Al}_{2} \mathrm{O}_{3}-\mathrm{SiO}_{2}-\mathrm{H}_{2} \mathrm{O}-\mathrm{TiO}_{2}-\mathrm{O}_{2}$ (MnNCKFMASHTO) system by Perple_X thermodynamic software $[30,102]$ with Grt endmember and $\mathrm{Si}-\mathrm{in}-\mathrm{Ph}$ content isopleths.

Similar $475-505{ }^{\circ} \mathrm{C}$ temperatures were obtained by Grt-Ph thermometry for 1.4-1.6 GPa pressures [100] (Table 10). This approximately coincides with phengite geobarometer pressures for Si content 3.43-3.51 a.p.f.u. at $500{ }^{\circ} \mathrm{C}$ [101]. This also considers a $\pm 0.2 \mathrm{GPa}$ error.

Figure 27 highlights that the post-peak metamorphic P-T conditions of blueschist from Šugov Valley near Medzev village (Figure 4C,D and Figure 17A) are in accordance with Chl-Ph pairs at $353^{\circ} \mathrm{C}$ and 1.1 GPa. This was accomplished with multi-equilibria Chl-Ph-Qtz- $\mathrm{H}_{2} \mathrm{O}$ geothermobarometry [43]. 
Table 10. $\mathrm{P}-\mathrm{T}$ estimates based on combined thermodynamic modelling and the geothermobarometry of Bôrka Unit rocks.

\begin{tabular}{|c|c|c|c|c|c|c|c|c|c|c|}
\hline \multirow[t]{2}{*}{ Sample } & \multirow{2}{*}{$\begin{array}{l}\text { Sample Description } \\
\text { and Locality }\end{array}$} & \multicolumn{2}{|c|}{$\begin{array}{c}\text { Perple_X } X \\
{[30,102]}\end{array}$} & \multirow{2}{*}{$\begin{array}{l}\text { Grt-Ph } \\
{[100]} \\
\mathrm{T}\left({ }^{\circ} \mathrm{C}\right)\end{array}$} & \multirow{2}{*}{$\begin{array}{l}\text { Cal-Dol } \\
{[109]} \\
\text { T }\left({ }^{\circ} \mathrm{C}\right)\end{array}$} & \multirow{2}{*}{$\begin{array}{c}\text { Chl } \\
{[43]} \\
T\left({ }^{\circ} \mathrm{C}\right)\end{array}$} & \multirow{2}{*}{$\begin{array}{c}\text { Chl-Ph } \\
\text { [43] } \\
\text { P (GPa) }\end{array}$} & \multirow{2}{*}{$\begin{array}{c}\text { Ph } \\
\text { [101] } \\
\text { P (GPa) }\end{array}$} & \multirow{2}{*}{$\begin{array}{c}\mathrm{Ch} \\
{[108]} \\
\mathrm{T}\left({ }^{\circ} \mathrm{C}\right)\end{array}$} & \multirow{2}{*}{$\begin{array}{c}\text { Mineral } \\
\text { Assemblage }\end{array}$} \\
\hline & & $\mathrm{T}\left({ }^{\circ} \mathrm{C}\right)$ & P (GPa) & & & & & & & \\
\hline HAC-1 & $\begin{array}{l}\text { Blueschist layer in } \\
\text { marble, Hačava }\end{array}$ & 520 & 1.55 & $\stackrel{*}{*}{ }^{*}-505$ & & & & & & Gln-Grt-Ph-Chl-Ep-Ab \\
\hline SUG-10 & $\begin{array}{l}\text { Blueschist layer in } \\
\text { marble, Šugov Valley } \\
\text { at Medzev }\end{array}$ & & & & & $335-353$ & $1.1-1.3$ & $1.5-1.6$ & 341 & Gln-Ph-Ttn-Chl-Ep-Ab \\
\hline DO-12 & $\begin{array}{l}\text { Blueschist lens in } \\
\text { serpentinite, Dobšiná }\end{array}$ & & & & & 281 & 0.4 & $0.45-0.85$ & 332 & $\mathrm{Gln}-\mathrm{Ph}-\mathrm{Chl}-\mathrm{Ep}-\mathrm{Ab}$ \\
\hline DO-31 & $\begin{array}{l}\text { Blueschist lens in } \\
\text { serpentinite, Dobšiná }\end{array}$ & & & & & & & $0.85-1.1$ & $245-257$ & Gln-Ph-Tlc-Chl-Ep-Ab \\
\hline MEL-11/19 & $\begin{array}{l}\text { Marble block in } \\
\text { flysch, Meliata }\end{array}$ & & & & $280-290$ & & & 0.6 & & Cal-Dol-Ph-Ap \\
\hline
\end{tabular}

${ }^{*}$ Calculated for pressures 1.4-1.6 GPa.

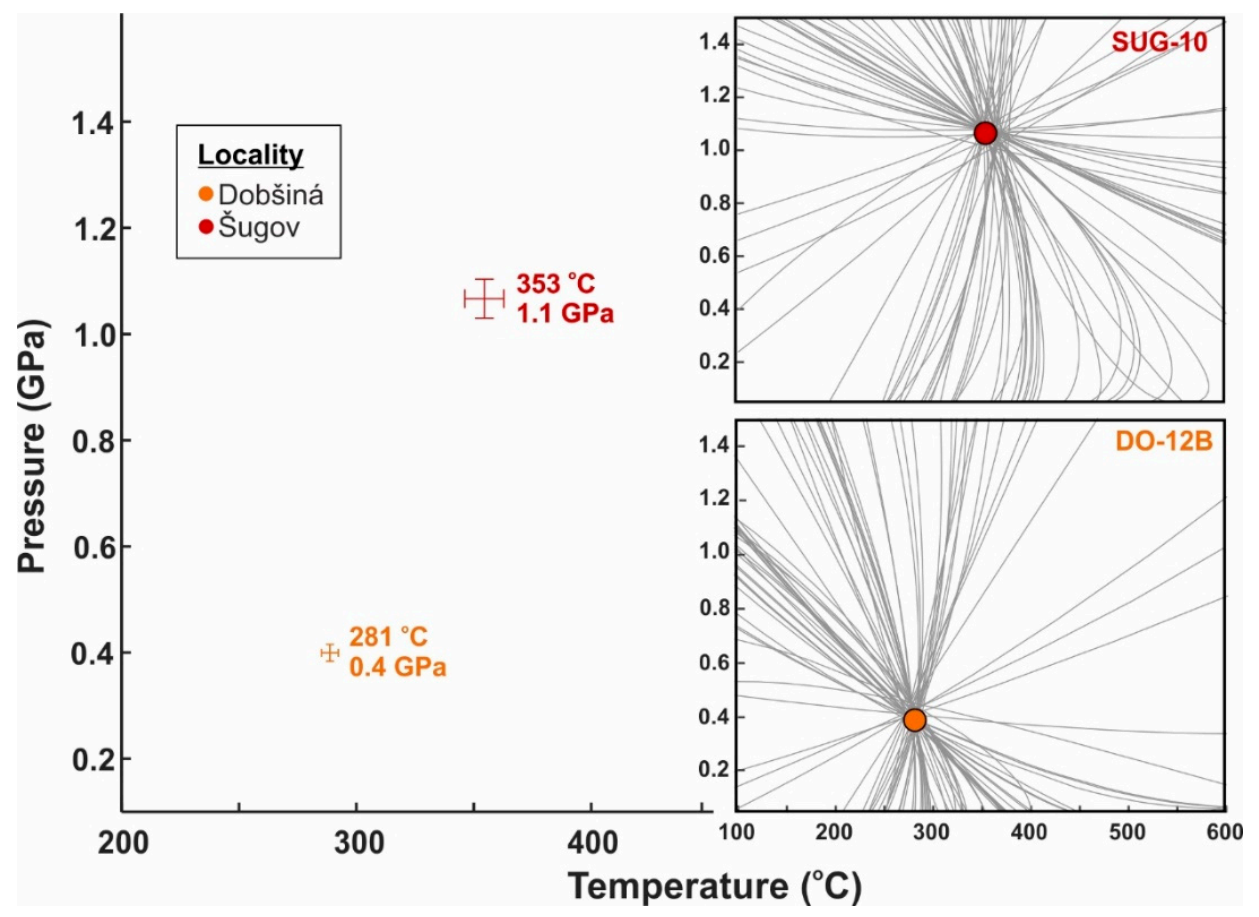

Figure 27. $\mathrm{P}-\mathrm{T}$ diagrams with univariant curves and points intersecting with $\mathrm{Chl}-\mathrm{Ph}$ pairs at equilibrium $\mathrm{P}-\mathrm{T}$ conditions $353^{\circ} \mathrm{C}$ at $1.1 \mathrm{GPa}$ and $281^{\circ} \mathrm{C}$ at $0.4 \mathrm{GPa}$. Bôrka Unit diagrams were created by MATLAB script provided by [43]. Crosses represent $\mathrm{Chl}-\mathrm{Ph}$ pairs equilibrium tolerance.

The geothermometry conventional method gives a similar Chl crystallisation temperature of $340^{\circ} \mathrm{C}$ at $1.5( \pm 0.2) \mathrm{GPa}$ [108]. This was obtained by Si-in-Ph geo-barometry for 3.51 a.p.f.u. Si content. (Tables 4 and 10).

The Chl-Ph pair in lensoidal blueschist fragments in serpentinite from Dobšiná quarry samples DO-12 and DO-31 provide $281^{\circ} \mathrm{C}$ and $0.4 \mathrm{GPa}$ (Figure 27). These P-T estimates were calculated from $\mathrm{Chl}$ replacing Gln and $\mathrm{Ph}$ with a lower 3.25 a.p.f.u. Si content (Table 2). However, we obtained pressures of $0.85-1.1( \pm 0.2) \mathrm{GPa}$ by combining $\mathrm{Chl}$ temperatures of approximately $330^{\circ} \mathrm{C}$ in the DO-12 sample and $245-257^{\circ} \mathrm{C}$ in DO-31 with a higher-Si Ph at 3.40-3.51 a.p.f.u. [43] (Table 4).

Marbles

Bôrka Unit marble block sample MEL-11/19 in Meliata Unit flysch contains Cal intergrown with tiny Dol grains (Figure 24D; Table 6). These carbonates yielded equilibrium temperatures of $286{ }^{\circ} \mathrm{C}$ by Cal-Dol thermometry [109] (Table 10). 


\subsubsection{Jaklovce Unit}

\section{Metabasites}

Perple_X pseudosection modelling determined the precise D1 stage P-T of the Jaklovce metabasalts greenschist-facies metamorphic veinlets (Figure 14A,B). This was accomplished by the calculated whole-rock composition of the studied rocks (Table 9). Figure 28 shows that the resultant P-T estimates of 390-420 ${ }^{\circ} \mathrm{C}$ at 1.1-1.3 GPa fit a peak D1 metamorphic Act-Chl-Ph-Ep-Ab-Ttn assemblage with a Chl composition of $\mathrm{Fe} /(\mathrm{Fe}+\mathrm{Mg})=0.36-0.38$ and $\mathrm{Si}$ in $\mathrm{Ph}$ 3.45-3.62 a.p.f.u. (Tables 4 and 5). For Ph, typical slightly lower values of $\mathrm{Si}$ were used, instead of maximal 3.62 a.p.f.u. to prevent pressure overestimation. These isopleths are crosscut by the Act composition of $\mathrm{Fe} /(\mathrm{Fe}+\mathrm{Mg})=0.30-0.40$ characteristic of the JAK-30 sample (Table 3).

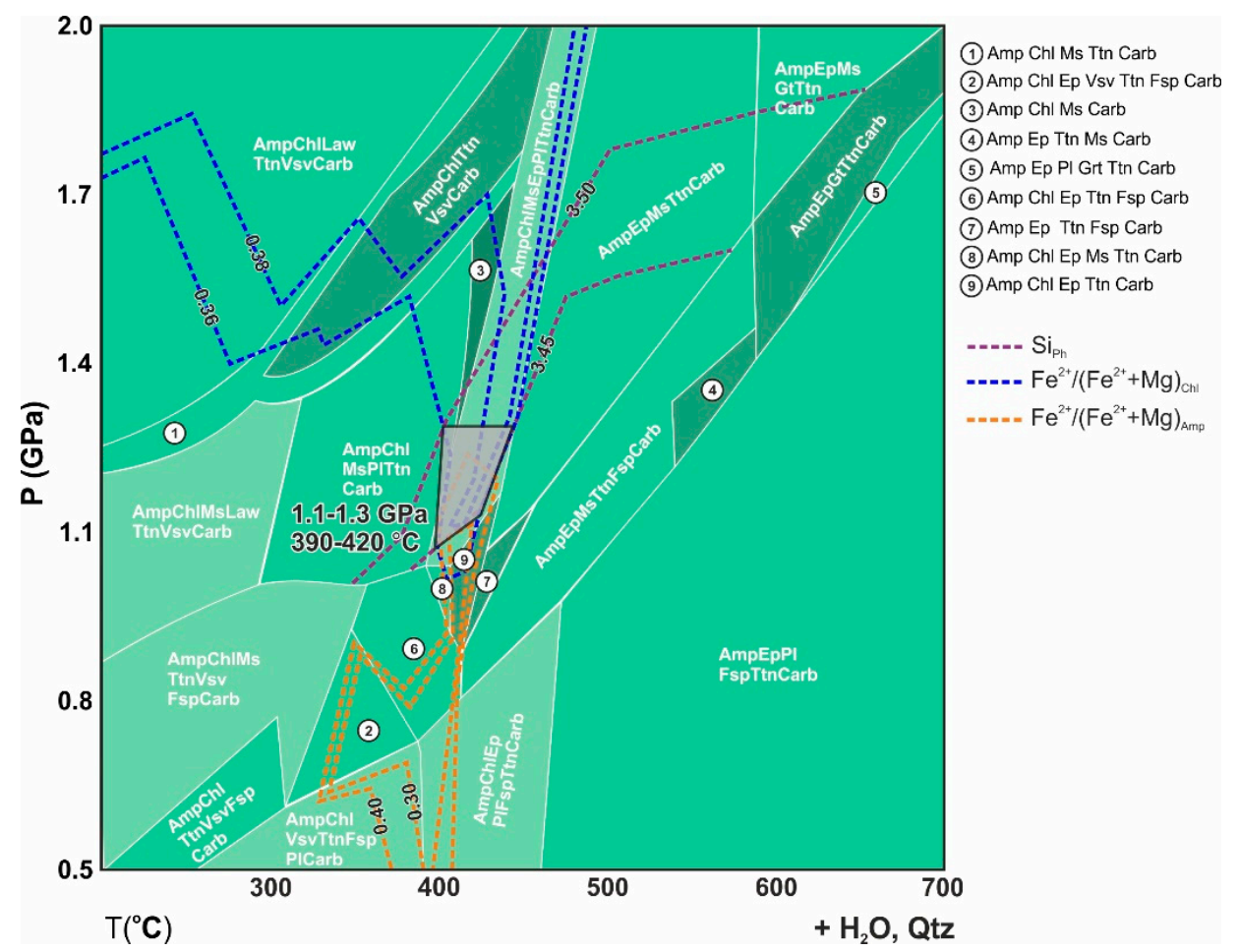

Figure 28. P-T pseudosection calculated for the Jaklovce metabasite D1 peak metamorphic stage using a modified composition of the JAK-30 sample (Table 9) in the NCKFMASTO system by Perple_X thermodynamic software $[30,102]$ with isopleths of $\mathrm{Fe} /(\mathrm{Fe}+\mathrm{Mg})$ for $\mathrm{Chl}$ and Act and content of Si-in-Ph.

Retrograde Chl temperatures for the blueschist MR-1 Malý Radzim/Brdárka are 306 or $278^{\circ} \mathrm{C}[43,108]$ (Figures 8F and 17B; Table 11).

In addition, greenschist rocks from Jaklovce Unit JAK-30 and JAK-6A, J-6 and 7 samples yield 261-310 ${ }^{\circ} \mathrm{C}$ temperature by [43] $\mathrm{Chl}$ thermometry and similar conditions $275-294{ }^{\circ} \mathrm{C}$ by [108] $\mathrm{Chl}$ thermometry (Figure 14A-F, Figures 7H and 17C,D; Table 11). Greenschist sample JAK-30 contains Ph1 in D1 peak metamorphic assemblage at 1.2-1.3 GPa pressure for 3.45-3.62 a.p.f.u. Si content [101] at given Chl temperatures (Tables 4 and 11). 
Table 11. Jaklovce Unit rock P-T estimates by combined geothermobarometry.

\begin{tabular}{|c|c|c|c|c|c|c|c|c|}
\hline Sample & $\begin{array}{c}\text { Sample } \\
\text { Description and } \\
\text { Locality }\end{array}$ & $\begin{array}{c}\text { Perple_X } \mathbf{X} \\
{[30,102]} \\
\text { T }\left({ }^{\circ} \mathrm{C}\right) \\
\end{array}$ & P (GPa) & $\begin{array}{l}\text { Chl } \\
{[43]} \\
\mathrm{T}\left({ }^{\circ} \mathrm{C}\right)\end{array}$ & $\begin{array}{c}\text { Chl-Ph } \\
\text { [43] } \\
\text { P (GPa) }\end{array}$ & $\begin{array}{c}\mathrm{Ph} \\
{[101]} \\
\mathbf{P}(\mathrm{GPa})\end{array}$ & $\begin{array}{l}\text { Chl } \\
{[108]} \\
T\left({ }^{\circ} \mathrm{C}\right)\end{array}$ & $\begin{array}{c}\text { Mineral } \\
\text { Assemblage }\end{array}$ \\
\hline JAK-6/19 & $\begin{array}{l}\text { Metaradiolarite, } \\
\text { Jaklovce }\end{array}$ & & & $250-266$ & 0.55 & $0.8-1.05$ & $300-327$ & Qtz-Ph-Chl \\
\hline JAK-204B & $\begin{array}{c}\text { Metaradiolarite, } \\
\text { Jaklovce }\end{array}$ & & & $234-245$ & 0.4 & $0.65-0.75$ & 310 & Qtz-Ph-Chl \\
\hline MR-1 & $\begin{array}{l}\text { Blueschist, Malý } \\
\text { Radzim at Brdárka }\end{array}$ & & & 306 & & & 278 & Gln-Chl-Ep-Ab \\
\hline JAK-30 & $\begin{array}{l}\text { Greenschist, } \\
\text { Jaklovce }\end{array}$ & $390-420$ & $1.1-1.3$ & $292-310$ & & $1.2-1.3$ & 266 & Act-Ph-Chl-Ep-Ab \\
\hline JAK-6A & $\begin{array}{l}\text { Greenschist, } \\
\text { Jaklovce }\end{array}$ & & & 278 & & & 294 & Act-Chl-Ep-Ab \\
\hline $\mathrm{J}-6$ & $\begin{array}{l}\text { Greenschist, } \\
\text { Jaklovce }\end{array}$ & & & 261 & & & 275 & Wnc-Chl-Ep-Ab \\
\hline MEL-15 & $\begin{array}{l}\text { Metabasalt block } \\
\text { in flysch, Meliata }\end{array}$ & & & 321 & & & 352 & $\mathrm{Chl}-\mathrm{Ab}-\mathrm{Cal}$ \\
\hline COL-1 & $\begin{array}{l}\text { Metabasalt block } \\
\text { in flysch, Meliata }\end{array}$ & & & & & & 256 & $\mathrm{Chl}-\mathrm{Ab}-\mathrm{Cal}$ \\
\hline DO-K2 & $\begin{array}{l}\text { Metaradiolarite, } \\
\text { Dobšiná - Končistá }\end{array}$ & & & $272-296$ & & $0.95-1.2$ & $291-310$ & Qtz-Ph-Chl \\
\hline
\end{tabular}

Metaradiolarites

Chl-Ph-Qtz multiequilibria geothermobarometry [43] for Jaklovce Unit JAK-204B and JAK-6/19 metaradiolarite samples yields $235-270{ }^{\circ} \mathrm{C}$ at 0.4-0.55 GPa (Figure 20A,B and Figure 29; Table 11). This is based on Chl-Ph equilibrium pairs. Similar Chl temperatures of approximately $300-327^{\circ} \mathrm{C}$ were obtained by $\mathrm{Chl}$ thermometry [108]. However, the entire 3.38-3.48 a.p.f.u. range of Si-in-Ph content indicates higher pressures of approximately 0.65-1.05 GPa at given Chl temperatures (Table 11).

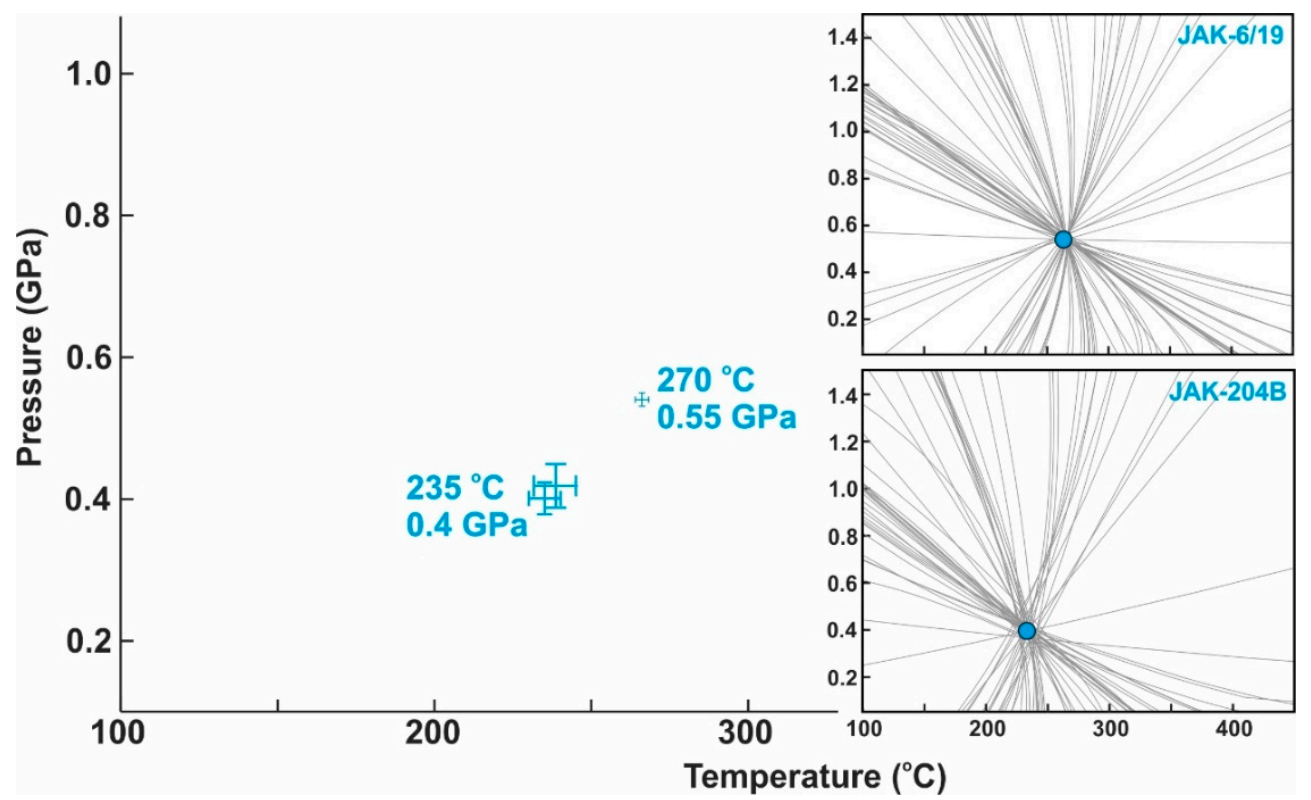

Figure 29. $\mathrm{P}-\mathrm{T}$ diagrams showing univariant curves and points intersecting $\mathrm{Chl}-\mathrm{Ph}$ pairs at equilibrium $\mathrm{P}-\mathrm{T}$ conditions of $270{ }^{\circ} \mathrm{C}$ at $0.55 \mathrm{GPa}$ (s. JAK-6/19) and $235{ }^{\circ} \mathrm{C}$ at $0.4 \mathrm{GPa}$ (s. JAK-204B). Jaklovce Unit diagrams were created by the MATLAB script provided by [43]. Crosses represent $\mathrm{Chl}-\mathrm{Ph}$ pairs equilibrium tolerance.

The metaradiolarite DO-K2 sample from Dobšiná-Končistá area has Chl temperatures of 272-296 ${ }^{\circ} \mathrm{C}$ [43] and 290-310 ${ }^{\circ} \mathrm{C}$ [108]. The Si-in-Ph barometry gives consequential peak metamorphic pressures at 0.95-1.2 GPa [101] (Figure 20C; Table 11). 


\subsubsection{Meliata Unit}

Flysch Metasediments

The JAK-204C siliciclastic flysch sample (Figure 20E) composition enabled P-T conditions to be calculated by Chl-Ph-Qtz geothermobarometry [43]. The Chl-Ph(Cel-Ms) pairs yielded $260{ }^{\circ} \mathrm{C}$ at $0.4 \mathrm{GPa}$ (Figure 30). However, the chlorite thermometer yields slightly higher temperatures at approximately $350{ }^{\circ} \mathrm{C}$ [108]. The inferred $\mathrm{Chl}$ temperatures indicate geo-barometric pressures of 0.4-0.6 GPa with Si-in-Cel-Ms = 3.21-3.28 a.p.f.u. [101] (Table 12).
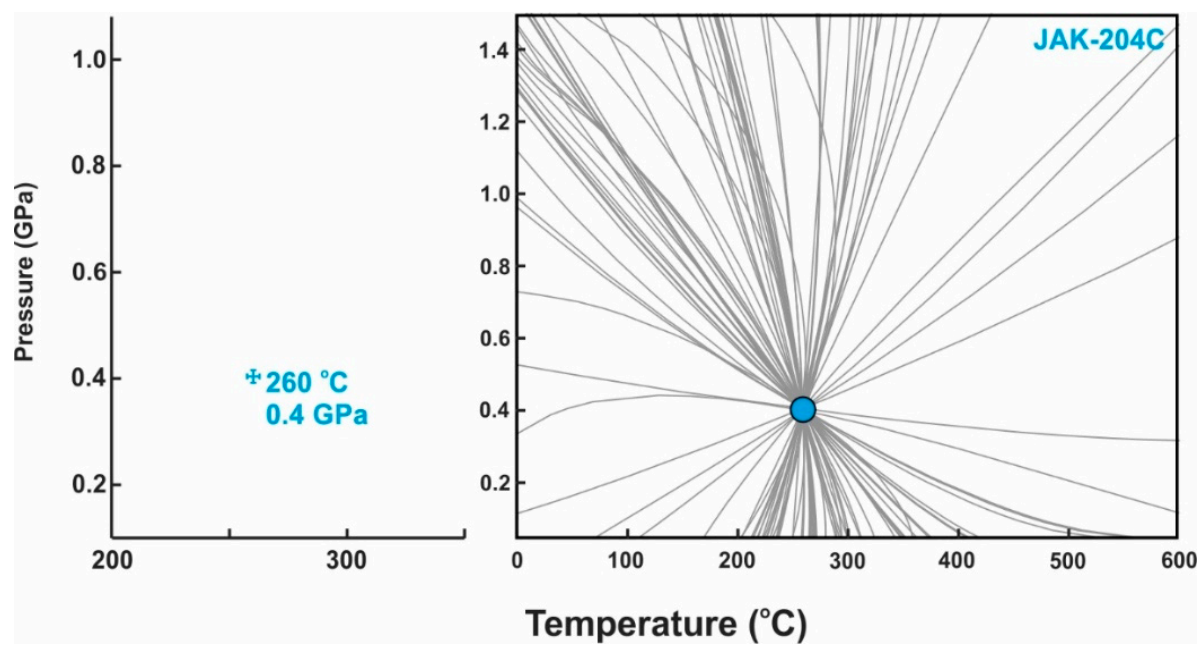

Figure 30. Meliata Unit $\mathrm{P}-\mathrm{T}$ diagrams showing univariant curves and the point intersecting $\mathrm{Chl}-\mathrm{Ph}(\mathrm{Cel}-\mathrm{Ms})$ pairs at equilibrium P-T conditions of $260^{\circ} \mathrm{C}$ at $0.4 \mathrm{GPa}$ (s. JAK-204C). Diagrams were created by MATLAB script [43]. Crosses represent $\mathrm{Chl-Ph}$ pairs equilibrium tolerance.

Table 12. Meliata Unit rock $\mathrm{P}-\mathrm{T}$ estimates from combined geothermobarometry.

\begin{tabular}{|c|c|c|c|c|c|c|c|}
\hline Sample & $\begin{array}{l}\text { Sample Description } \\
\text { and Locality }\end{array}$ & $\begin{array}{l}\text { Cal-Dol } \\
{[109]} \\
\text { T }\left({ }^{\circ} \mathrm{C}\right)\end{array}$ & $\begin{array}{l}\text { Chl } \\
{[43]} \\
\text { T }\left({ }^{\circ} \mathrm{C}\right)\end{array}$ & $\begin{array}{l}\text { Chl-Ph } \\
\quad[43] \\
\text { P (GPa) }\end{array}$ & $\begin{array}{c}\mathrm{Ph} \\
{[101]} \\
\mathrm{P}(\mathrm{GPa})\end{array}$ & $\begin{array}{l}\text { Chl } \\
{[108]} \\
\text { T }\left({ }^{\circ} \mathrm{C}\right)\end{array}$ & $\begin{array}{c}\text { Mineral } \\
\text { Assemblage }\end{array}$ \\
\hline JAK-202B & $\begin{array}{l}\text { Calciclastic flysch } \\
\text { Jaklovce }\end{array}$ & $284-323$ & & & & & Cal-Dol-Ab-Kfs-Qtz \\
\hline JAK-204C & $\begin{array}{c}\text { Siliciclastic flysch, } \\
\text { Jaklovce }\end{array}$ & & 260 & 0.4 & $0.4-0.6$ & 348 & clast(Ms)-Qtz-Chl-Cel-Ms-Ab \\
\hline MEL-14/19 & $\begin{array}{l}\text { Black-gray radiolarite } \\
\text { layer in siliciclastic } \\
\text { flysch, Meliata }\end{array}$ & & 296 & & & 340 & Qtz-Chl \\
\hline MEL-17B/19 & $\begin{array}{l}\text { Contact of dark red } \\
\text { radiolarite layer with } \\
\text { flysch, Meliata }\end{array}$ & & $305-323$ & & & $341-355$ & clasts(Chl-Ms-Rt)-Qtz-Chl \\
\hline
\end{tabular}

Calciclastic flysch from Jaklovce Unit samples JAK-202 A and B contain Cal-Dol intergrowths which yield $335-350{ }^{\circ} \mathrm{C}$ equilibrium temperature from Cal-Dol solvus thermometry [109] (Figure 24A-C).

\section{Metaradiolarites}

Sample MEL-17B/19 from Meliata Unit flysch metaradiolarite layer contains a newly formed Chl which yielded temperatures of $296-323{ }^{\circ} \mathrm{C}$ [43] and $340-355{ }^{\circ} \mathrm{C}$ [108] (Figure 20F; Table 12).

PXRD Results in P-T Estimates

The Chl and Cal-Dol geothermobarometry results are supported by Ms and Chl PXRD patterns. The full width at half maximum (FWHM) for selected diffraction maxima (002) of Ms, (001) and (002) of Chl show decreasing values in Ms (Kübler index-KI [116-118]) and Chl (Árkai index [119]) indicates diagenetic zone $\left(\mathrm{KI}>0.42 \Delta^{\circ} 2 \theta \mathrm{CuK} \alpha,<200{ }^{\circ} \mathrm{C}\right)$, anchizone $\left(0.42>\mathrm{KI}>0.25 \Delta^{\circ} 2 \theta \mathrm{CuK} \alpha\right.$, 
$\left.<300{ }^{\circ} \mathrm{C}\right)$ and epizone $\left(\mathrm{KI}<0.25 \Delta^{\circ} 2 \theta \mathrm{CuK} \alpha,>300{ }^{\circ} \mathrm{C}\right)$. The PXRD measurement and following peak-shape fitting (Table 13) were not calibrated for the studied samples, and the data were used only as the additional support for the determination of P-T conditions. However, the comparison of calibrated and uncalibrated illite measurement shows that variations and differences are smaller in the epizone samples than in anchizone and diagenetic illite [120]. Both values for Ms and Chl from the studied samples indicate their crystallisation at the epizone greenschist facies conditions, with a good correlation between these minerals (Figures 31 and 32). The estimation of metamorphic conditions for both minerals is safely within the epizone, and this reduces the possibility of data misinterpretation. Consequently, the studied samples most likely experienced at least $300{ }^{\circ} \mathrm{C}$ which supports $\mathrm{Chl}$ and Cal-Dol geothermobarometry results.

Table 13. Meliata Unit flysch metasediments. Full width at half maximum of selected Chl and Ms diffraction maxima at $\Delta^{\circ} 2 \theta \mathrm{CuK} \alpha$.

\begin{tabular}{|c|c|c|c|c|c|c|c|c|c|c|c|}
\hline Phase & $\begin{array}{l}\text { Diffraction } \\
\text { maxima }\end{array}$ & DO-F1 & DO-F2 & DO-K11 & JAK-202A & JAK-202B & MEL-2/19 & MEL-3/19 & MEL-10/19 & MEL-13/19 & MEL-18/19 \\
\hline Chlorite & (001) & 0.077 & 0.075 & 0.070 & 0.069 & 0.081 & 0.136 & 0.073 & 0.089 & 0.171 & 0.079 \\
\hline Muscovite & (002) & 0.076 & 0.082 & 0.077 & 0.076 & 0.095 & 0.095 & 0.125 & 0.090 & 0.152 & 0.120 \\
\hline Chlorite & (002) & 0.064 & 0.061 & 0.057 & 0.104 & 0.101 & 0.110 & 0.067 & 0.075 & 0.109 & 0.069 \\
\hline
\end{tabular}
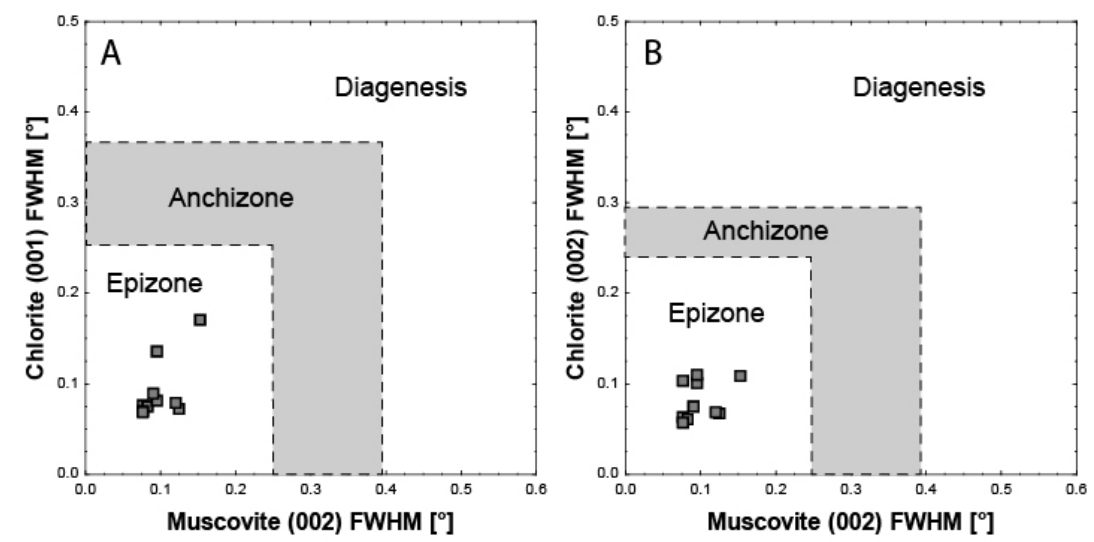

Figure 31. Determination of diagenetic zone, anchizone and epizone in Meliata Unit flysch metasediments from the comparison of Ms (002), Chl (001) (A) and Chl (002) (B) diffraction maxima FWHM values from [121]. Values from Table 13.
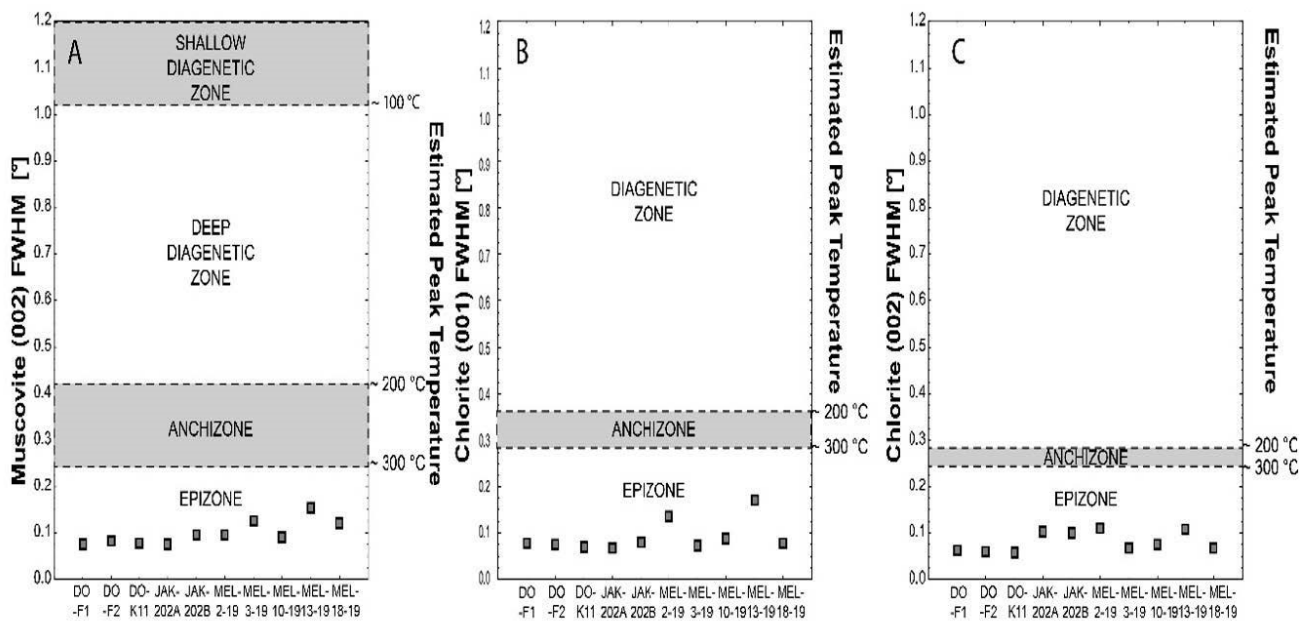

Figure 32. Determination of diagenetic zone, anchizone and epizone in Meliata Unit flysch metasediments from the comparison of Ms (002) (A) and Chl (001) (B) and (002) (C) diffraction maxima FWHM values according to [122,123]. Values from Table 13. 


\subsubsection{Silica Nappe Hanging Wall Mélange}

Figures 18 and 19 depict the relic magmatic Mhs and Mh in the Silica Unit amphibole metagabbro sample SA-6. These provided temperatures of magmatic crystallisation at $880-803 \pm 22{ }^{\circ} \mathrm{C}$ and $1.88 \pm 0.21-0.79 \pm 0.09$ GPa by [110].

\section{Discussion}

This study provides a comprehensive analysis of metamorphic conditions determined in the IWC Meliatic Superunit, which is also called Meliaticum. Three basic paleotectonic units of Meliaticum [48] were subjected to variable P-T conditions (Figures 33 and 34; Table 14).

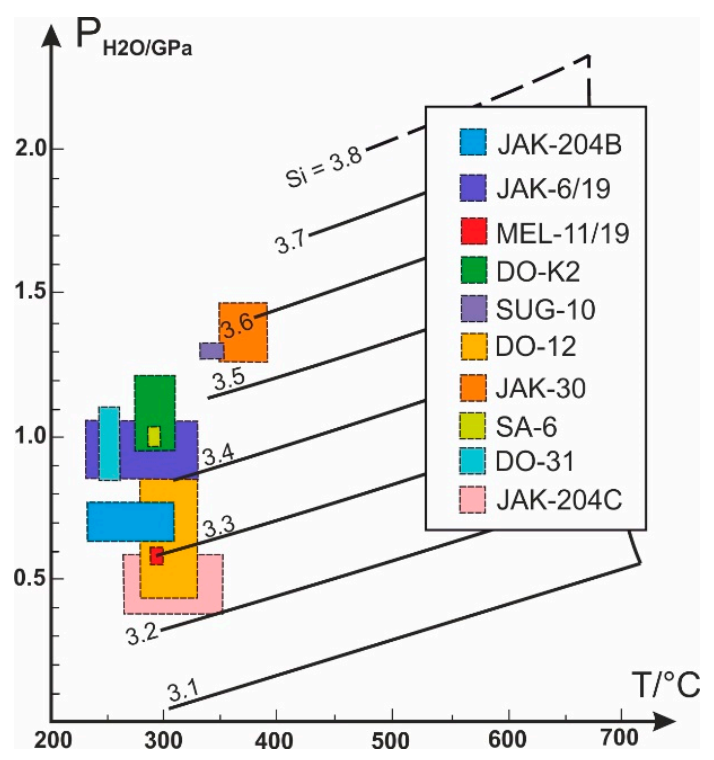

Figure 33. Pressure estimates diagram after [101] of Meliatic metamorphic rocks; temperatures derived from Chl thermometry by [108]. Bôrka Unit: SUG-10, DO-12B, DO-31; Jaklovce Unit: JAK-30, JAK-204B, JAK-6/19; Meliata Unit: JAK-204C, MEL-11/19 (olistolith of Bôrka Unit); Sillica Nappe: SA-6.

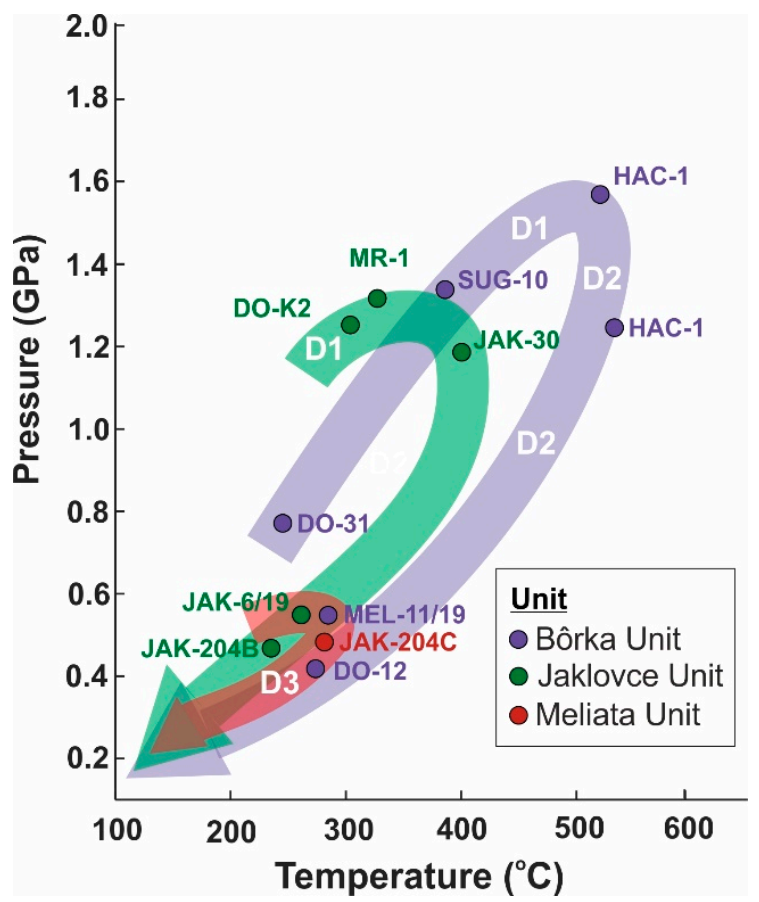

Figure 34. Estimated P-T paths from Meliatic Superunit. Review of P-T data in Table 14. 
Table 14. Review of P-T estimates from the Meliatic units used in reconstructing the P-T paths (Figure 34).

\begin{tabular}{|c|c|c|c|c|c|c|c|c|c|c|}
\hline \multirow[t]{2}{*}{ Sample } & \multirow[t]{2}{*}{ Sample Description and Locality } & \multicolumn{2}{|c|}{$\begin{array}{c}\text { Perple_X } \\
{[30,102]}\end{array}$} & \multirow{2}{*}{$\begin{array}{c}\text { Grt-Ph } \\
{[100]} \\
T\left({ }^{\circ} \mathrm{C}\right)\end{array}$} & \multirow{2}{*}{$\begin{array}{c}\text { Cal-Dol } \\
{[109]} \\
\mathrm{T}\left({ }^{\circ} \mathrm{C}\right)\end{array}$} & \multirow{2}{*}{$\begin{array}{c}\text { Chl } \\
{[43]} \\
\text { T }\left({ }^{\circ} \mathrm{C}\right)\end{array}$} & \multirow{2}{*}{$\begin{array}{c}\text { Chl-Ph } \\
\text { [43] } \\
\text { P (GPa) }\end{array}$} & \multirow{2}{*}{$\begin{array}{c}\text { Ph } \\
\text { [101] } \\
\mathbf{P}(\mathrm{GPa})\end{array}$} & \multirow{2}{*}{$\begin{array}{l}\text { Chl } \\
{[108]} \\
\text { T }\left(^{\circ} \mathrm{C}\right)\end{array}$} & \multirow{2}{*}{$\begin{array}{c}\text { Mineral } \\
\text { Assemblage }\end{array}$} \\
\hline & & $\mathrm{T}\left({ }^{\circ} \mathrm{C}\right)$ & P (GPa) & & & & & & & \\
\hline & & \multicolumn{9}{|c|}{ Bôrka Unit } \\
\hline HAC-1 & Blueschist layer in marble, Hačava & 520 & 1.55 & $* 475-505$ & & & & & & Gln-Grt-Ph-Chl-Ep-Ab \\
\hline SUG-10 & $\begin{array}{l}\text { Blueschist layer in marble, Šugov Valley } \\
\text { at Medzev }\end{array}$ & & & & & $335-353$ & $1.1-1.3$ & $1.5-1.6$ & 341 & Gln-Ph-Ttn-Chl-Ep-Ab \\
\hline DO-12 & Blueschist lens in serpentinite, Dobšiná & & & & & 281 & 0.4 & $0.45-0.85$ & 332 & Gln-Ph-Chl-Ep-Ab \\
\hline DO-31 & Blueschist lens in serpentinite, Dobšiná & & & & & & & $0.85-1.1$ & $245-257$ & Gln-Ph-Tlc-Chl-Ep-Ab \\
\hline \multirow[t]{2}{*}{ MEL-11/19 } & Marble block in flysch, Meliata & & & & $280-290$ & & & 0.6 & & Cal-Dol-Ph-Ap \\
\hline & & \multicolumn{9}{|c|}{ Jaklovce Unit } \\
\hline JAK-6/19 & Metaradiolarite, Jaklovce & & & & & $200-266$ & 0.55 & $0.8-1.05$ & $300-327$ & Qtz-Ph-Chl \\
\hline JAK-204B & Metaradiolarite, Jaklovce & & & & & $234-245$ & 0.4 & $0.65-0.75$ & 310 & Qtz-Ph-Chl \\
\hline MR-1 & Blueschist, Malý Radzim at Brdárka & & & & & 306 & & & 278 & Gln-Chl-Ep-Ab \\
\hline JAK-30 & Greenschist, Jaklovce & $390-420$ & $1.1-1.3$ & & & 292-310 & & $1.2-1.3$ & 266 & Act-Ph-Chl-Ep-Ab \\
\hline \multirow[t]{2}{*}{ DO-K2 } & Metaradiolarite, Dobšiná-Končistá & & & & & $272-296$ & & $0.95-1.2$ & 291-310 & Qtz-Ph-Chl \\
\hline & & \multicolumn{9}{|c|}{ Meliata Unit } \\
\hline JAK-204C & Siliciclastic flysch, Jaklovce & & & & & 260 & 0.4 & $0.4-0.6$ & 348 & clast(Ms)-Qtz -Chl-Ph-Ab \\
\hline
\end{tabular}

${ }^{*}$ Calculated for pressures 1.4-1.6 GPa 


\subsection{The Bôrka Unit}

Blueschist samples do not contain any preserved magmatic assemblages nor do they show any differences in the texture, pointing out that the bulk composition re-equilibrated well during the metamorphic overprint [124]. The modelled pseudosection (Figure 26; sample HAC-1) then matches quite well the observed mineral assemblage of $\mathrm{Gln}, \mathrm{Ph}, \mathrm{Grt}, \mathrm{Chl}, \pm \mathrm{Bt}, \mathrm{Ep}, \mathrm{Ab}$ in the studied rocks (Figures 6A and 15A,B).

Garnet grains regardless of their size in the studied samples show increasing values of Alm and Grs while exhibiting decreasing Sps indicating garnet growth during the prograde metamorphic conditions $[125,126]$ (Figure 16A-D). Based on these observations, the garnets rim composition with the highest Alm and Grs values coupled with the lowest Sps will reflect the peak D1 stage P-T conditions (Table 2, Figure 26). The growth histories are generally lost in garnets that have attained a temperature in excess of $600-700{ }^{\circ} \mathrm{C}[126,127]$ which indicates lower temperatures during the growth of the garnet in the investigated blueschists.

The growth of an additional thin outer zone around the garnets most likely reflects a $\mathrm{P}-\mathrm{T}$ decrease during the D2 exhumation stage (Figure 16C-E).

Widening the miscibility gap between muscovite and celadonite with either rising pressure or decreasing temperature was initially reported by $[128,129]$, thus confirming the pressure dependency of $\mathrm{Si}^{4+}$ in Ph (inverse Tschermak's substitution of $\mathrm{Mg}^{2+}+\mathrm{Si}^{4+}$ for $2 \mathrm{Al}^{3+}$ ) used in the geothermobarometry of phengite bearing metamorphic rocks $[101,130,131]$. Analyses with the highest Si substitution in Cel-Ms (Table 4) were therefore used with the garnet isopleths to model the peak D1 stage P-T estimates.

White micas from metabasites exhibit variable $\mathrm{Si}^{4+}$ substitution (Figure 33, Table 4), where $\mathrm{Si}$ decreases with pressure during exhumation processes $[101,130,131]$. This provides us with a wider pressure interval of 0.4-1.6 GPa based on Ph barometers indicating different burial/exhumation depths. Moreover, the content of ${ }^{\mathrm{VI}} \mathrm{Al}$ in all the studied samples from the Bôrka Unit is typical for low-crystallisation temperatures [108], giving an interval of approximately $250-350^{\circ} \mathrm{C}$ (Figure 33; Tables 10 and 14). These data mostly constrain the post-peak D2 stage exhumation conditions. This is also true for Chl-Ph-Qtz geothermobarometry with a similar range of estimates, showing a microscale equilibration of Chl-Ph pairs at different P-T conditions during exhumation (Figure 27; Tables 10 and 14).

Perple_X pseudosection modelling shows that the Bôrka Unit of the Meliatic continental margin underwent $\mathrm{HP}$ blueschist facies metamorphism at approximately $520^{\circ} \mathrm{C}$ and $1.55 \mathrm{GPa}$ (Figure 26). This is compatible with the peak Grt-Gln-Ph assemblage from the D1 stage subductional burial to maximum ca. $50 \mathrm{~km}$ depth following the closure of the Neotethys Meliata Basin.

Former estimates reported slightly lower $\mathrm{P}-\mathrm{T}$ conditions in greenschist to epidote-blueschists facies at $380-460^{\circ} \mathrm{C}$ and $1.2-1.3 \mathrm{GPa}$ peak pressure. In addition, estimates at $400-460{ }^{\circ} \mathrm{C}$ and $1.05-1.2 \mathrm{GPa}$ and $360-400{ }^{\circ} \mathrm{C}$ at $0.8 \mathrm{GPa}$ were provided for glaucophane, pyroxene and chloritoid-bearing metapelitic to metapsammitic rocks $[63,64]$. However, the [71] estimated $520-620{ }^{\circ} \mathrm{C}$ and $1.1-1.4$ GPa peak metamorphic conditions for metapelites from basal parts of the Bôrka Nappe have slightly lower pressures and overestimated temperatures.

\subsection{The Jaklovce Unit}

The Jaklovce metabasalts differ from the investigated Bôrka Unit blueschist samples by having clear textural differences in some parts of the rocks. The metamorphic overprinting in the Jaklovce Unit metabasalts, metadolerites, metaradiolarites and siliceous metacarbonates, in the form of metamorphic veinlet networks crosscutting homogeneous parts of these rocks, suggests a significant amount of metamorphic fluids.

These metabasalts have partly preserved magmatic textures crosscut by meso- and microscopically visible metamorphic veinlets (Figures 12A and 14A). We, therefore, calculated the 'bulk' whole-rock composition for Perple_X modelling from representative metamorphic veins. The resultant bulk has a higher $\mathrm{CaO}$ and $\mathrm{MgO}$ content linked to $\mathrm{Cal}, \mathrm{Ep}$ and $\mathrm{Chl}$ in the veinlets compared to the homogeneous part of metabasalt bulk. There is also a small increase in $\mathrm{K}_{2} \mathrm{O}$ linked to newly formed $\mathrm{Ph}$ in veinlets. 
The remaining $\mathrm{SiO}_{2}, \mathrm{Al}_{2} \mathrm{O}_{3}$ and $\mathrm{Na}_{2} \mathrm{O}$ oxides related to $\mathrm{Pl}-\mathrm{Aug}$ relic magmatic texture have on the other hand higher contents than an estimated bulk composition of metamorphic veinlets (Table 9).

Perple_X pseudosection modelling of Jaklovce metabasalt sample JAK-30 metamorphic veinlet mineral assemblage provided P-T conditions of approximately $390-420{ }^{\circ} \mathrm{C}$ at $1.1-1.3 \mathrm{GPa}$ (Figure 28). This is consistent with an observed assemblage of Act-Chl-Ph-Ep-Ab-Ttn in veinlets. These inferred the D1 stage peak metamorphic conditions indicate maximum burial of this Jaklovce Unit oceanic crust fragment to a maximum $35-40 \mathrm{~km}$ depth in a subduction channel.

Chlorite IV Al values are typical for low-temperature crystallisation [108] resulting in an approximately $200-330{ }^{\circ} \mathrm{C}$ interval, with the highest ${ }^{\mathrm{IV}} \mathrm{Al}$ reflecting conditions close to the peak D1 stage (Figure 33, Tables 5 and 14), likewise in the Bôrka Unit. Furthermore, Act amphibole exhibits a low content of ${ }^{~}{ }^{\mathrm{A}} \mathrm{A}$ common for low crystallisation metamorphic condition in low-greenschist facies (Table 3, Figure 18D,E). Typical zonality of Act amphibole (Figure 17C,D) with Wnc/Fwn rims and rare Mrbk implies several metamorphic phases. A prograde D1 stage increase in pressure is corroborated by Na-rich Amp rims, and a lower-pressure Act in outermost rims may occur due to D2-stage exhumation in greenschist facies. Finally, the single MR-1 (N-MORB type) metabasalt sample of this unit contains Gln and documents oceanic HP subduction. The different pressure conditions are also further confirmed by variable $\mathrm{Si}^{4+}$ content in Cel-Ms from metasilicites to impure metaradiolarites provide broad pressure estimates between 1.3 and 0.4 GPa (Figures 29 and 33; Tables 11 and 14) consequently reflecting different D1 burial/D2 exhumation depths. These conditions are consistent with the determined Mrbk, Fwn, Act, Chl, Ab, Ep and Ph mineral assemblages.

Chlorite thermometry and Chl-Ph-Qtz and Ph barometry determined that both N-MORB metabasalts to metadolerites and the associated metaradiolarites were mostly subducted to medium-pressure depths. In addition, $600 \mathrm{MPa}$ pressure was estimated for the Jaklovce metabasalt Fwn [73] by the empiric [74] $\mathrm{Al}^{\mathrm{IV}}$ geobarometer compared to the $\mathrm{Na}^{\mathrm{B}}$ result. This could be a Mrbk minimum pressure.

However, Bretka Mhb epidote amphibolites may indicate the base of the obducted and thrust oceanic crust slices onto the exhuming continental margin wedge. Finally, the Bretka amphibolites may suggest the P-T conditions achieved due to the ridge subduction of the lower oceanic plate.

Sample SA-6 metagabbro in the Silica Nappe hanging wall at Gemerská Hôrka is considered a detached exhumed Meliatic oceanic fragment included in the Permian salinar mélange during the Cretaceous Silica Nappe overthrusting. Estimated Amp magmatic crystallisation temperatures of $880-803 \pm 22{ }^{\circ} \mathrm{C}$ and $1.88 \pm 0.21-0.79 \pm 0.09 \mathrm{GPa}$ in pressures imply a crystallisation depth of $3-5 \mathrm{~km}$. These higher temperatures and low pressures are obviously related to amphibole gabbro magmatic emplacement and crystallisation in the inferred oceanic crust. In addition, the newly formed Mrbk, Act, Ep, Ab , Chl, \pm Cal and \pm Qtz assemblage most likely indicate metamorphic overprinting in medium pressure greenschist facies. This is comparable to Jaklovce Unit metabasites.

\subsection{The Meliata Unit}

Continental and oceanic margin flysch metasediments contain newly formed $\mathrm{Ab}$, Kfs and Chl associated with Qtz and/or Cal and Dol in both siliciclastic and calciclastic lithotypes. Chlorite thermometry and Chl-Ph thermobarometry (Figure 30) provided variable temperatures which may record different re-equilibration conditions of the individual Chl along the P-T path. Similarly, Cal-Dol solvus thermometry yielded $286^{\circ} \mathrm{C}$ and $0.6 \mathrm{GPa}$ from Ph barometry (Figure 33) in a marble olistolith in flysch. Former estimates on the Meliata Unit metamorphic overprinting at approximately $250-350{ }^{\circ} \mathrm{C}$ and 350-540 MPa [54] overlap our reported values.

PXRD study revealed rejuvenated clastogenic and newly formed white mica phases. The values of full width at half maximum (FWHM) for selected diffraction maxima (002) of Ms, (001) and (002) of Chl depend on the P-T conditions in the diagenetic zone to greenschists facies [116-118,121-123,132]. The decreasing value of FWHM in Ms (Kübler's index-KI [116-118]) and Chl (Árkai's index [119]) 
indicates a diagenetic zone $\left(\mathrm{KI}>0.42 \Delta^{\circ} 2 \theta \mathrm{CuK} \alpha,<200{ }^{\circ} \mathrm{C}\right)$, anchizone $\left(0.42>\mathrm{KI}>0.25 \Delta^{\circ} 2 \theta \mathrm{CuK} \alpha\right.$, $300{ }^{\circ} \mathrm{C}$ ) and epizone $\left(\mathrm{KI}<0.25 \Delta^{\circ} 2 \theta \mathrm{CuK} \alpha,>300^{\circ} \mathrm{C}\right)$, which correspond to greenschist facies [122,123].

Crystallographic characteristics in the studied flysch samples which indicate epizonal metamorphic conditions around or slightly above $300{ }^{\circ} \mathrm{C}$ (Figures 31 and 32; Tables 4 and 13), may explain the formation of low-T Kfs, most likely at the expense of $\mathrm{K}$ released from rejuvenated clastogenic Ms which has a compositional trend to illite (Figure 22A,B). Many samples, especially those from the Jaklovce Unit, have white mica of transitional illite-phengite composition with decreased $(\mathrm{Na}+\mathrm{K})$ and $\mathrm{K}_{2} \mathrm{O}$ contents typical of anchimetamorphic conditions (Figures 10 and 20; Table 4) [133,134]. The correlation between illite crystallinity and mica $\mathrm{K}_{2} \mathrm{O}$ content was described from the diagenetic grade to the epizone by [135]. The occupancy of the interlayer position of the micas gradually increases, and the $(\mathrm{K}+\mathrm{Na})$ content of the illite-muscovite increases from 0.65 to 0.9-1.0 a.p.f.u. Moreover, analyses of the phengitic white mica exhibit a small but significant deficit in the interchange layer [114]. The total interlayer charge (t.i.c.) calculated for 22 oxygens is approximately 1.7 a.p.f.u, and this is characteristic for Phengitic anchizonal white mica [114,135-137]. These Meliata Unit data confirm the previous results of [54].

This suggests the relatively shallow burial of the Meliata Unit olistostromatic formation (at Meliata village) in an accretionary wedge to approximately $12-14 \mathrm{~km}$ at $290-350{ }^{\circ} \mathrm{C}$ and $0.4-0.5 \mathrm{GPa}$ (Figure 30; Tables 12 and 14).

The contrasting metamorphic conditions in Meliata and Jaklovce units do not support the interpretation of [55] that Meliata and Jaklovce sections of the Meliaticum form one paleotectonic unit with negligible metamorphic overprinting. The determined metamorphic conditions are specific for all three partial units of the Meliaticum and therefore match the subduction/obduction-related accretionary wedge model suggested by [48].

Two, or more often all three Meliaticum paleotectonic units were incorporated in kilometre-size mélange blocks, and this indicates the transformation of the D1-D2 stage subduction-related accretionary wedge into a late D2-D3 stage mélange. Present day nappe outliers of the Meliaticum incorporate different mélange blocks overlying the Gemeric, and less the Veporic superunits of the IWC [95].

\section{Conclusions}

The application of thermodynamic modelling combined with the chosen geothermobarometers revealed the following metamorphic conditions in the Meliatic paleotectonic units after the closure of the Neotethyan oceanic Meliata Basin.

The Bôrka Unit of the Neotethyan northern continental margin achieved subductional burial to a maximum depth of $50 \mathrm{~km}$. This is constrained by the Perple_X modelling of the D1 stage metamorphic peak P-T conditions of the HP blueschist facies at approximately $520{ }^{\circ} \mathrm{C}$ and $1.55 \mathrm{GPa}$. Confirmation is further supported by Grt-Gln-Ph D1 mineral paragenesis in the blueschists. Chl-Ph-Qtz geothermobarometry revealed a wider pressure interval of 0.4-1.6 GPa during D2 stage exhumation indicating different burial/exhumation depts. Chlorite thermometry provided temperatures of approximately $250-350{ }^{\circ} \mathrm{C}$.

The Jaklovce Unit oceanic sliver slices were subjected to MP to HP subduction. The metamorphic conditions of $390-420^{\circ} \mathrm{C}$ at $1.1-1.3 \mathrm{GPa}(\sim 35-40 \mathrm{~km}$ subductional burial) of inferred D1 stage were provided by Perple_X modelling. Interlayered metacherts to metaradiolarites underwent consistent $\mathrm{P} / \mathrm{T}$ conditions. The metamorphic P-T conditions of ca. $200-330^{\circ} \mathrm{C}$ and $0.4-1.3 \mathrm{GPa}$ from the metamorphic vein mineral assemblages of Mrbk, Wnc, Act, Ab, Ep, Chl, Ph, Cal in metabasalts and metadolerites were constrained by the combination of $\mathrm{Ph}$ barometry and $\mathrm{Ph}-\mathrm{Chl}$ and $\mathrm{Chl}$ thermometry. A single N-MORB type metabasalt with Gln suggests blueschist facies conditions in this subducted oceanic crust fragment. Exceptionally, epidote-amphibolite facies conditions were recorded in Bretka N-MORB type amphibolites which constrain the cooled base of an obducted oceanic crust sliver onto a continental margin wedge. 
The Meliata Unit (former Meliata Unit s.s.) flysch metasediments yielded the shallowest subduction, or just a burial within the accretionary wedge to ca. $12-14 \mathrm{~km}$ at ca. $290-350{ }^{\circ} \mathrm{C}$ and $0.4-0.5 \mathrm{GPa}$ that is consistent with the newly formed Ill-Ph to Ph, Qtz, Chl, Ab, Kfs, Cal and Dol.

The metamorphism of Meliaticum documents the metamorphic conditions from the D1 stage subductional burial of the Bôrka and Jaklovce units and serpentinites to the D2 stage exhumation from a subduction channel of those elements into an accretionary wedge with Meliata Unit flysch in the Late Jurassic to Early Cretaceous.

The analysis of the Meliaticum metamorphic conditions, structural observations and the published litho-geochemical and geochronological dataset [48] revealed the three principal paleotectonic Bôrka, Jaklovce and Meliata units which were transformed into three major tectonic units. Although these units have different reconstructed metamorphic P-T paths, they fit to the Meliaticum D1 and D2 stage subduction/obduction-related accretionary wedge evolution. The character of the Meliatic nappe outliers as mélange blocks incorporating different paleotectonic units with different metamorphic overprinting grade implies the late D2 and D3 stage break-up of this wedge into fragments which overloaded the passive Gemeric type continental margin being thrust further northwestward in the AD1 stage of the IWC orogenic wedge.

Supplementary Materials: The following are available online at http://www.mdpi.com/2075-163X/10/12/1094/s1, Figure S1: Rounded block $(4 \times 3 \mathrm{~m})$ of a calc-alkaline blueschist (sample DO-31) exhumed during D2 stage in serpentinite mélange (late D2-D3 stage) with marbles, Tlc-Chl-Ph-Cal schists, rodingites and alkaline OIB-type blueschist-facies metabasalts in the southern part of the Dobšiná quarry. The blueschist block is internally fragmented $[48,138]$. Figure S2: Serpentinised harzburgite with rodingite vein exhumed during the D2 stage in the serpentinite mélange (late D2-D3 stage). Internal structure of a Meliatic mélange block in the northern part of the Dobšiná quarry, shown in the red circle. Erosion furrow with violet Permian siliciclastic metasediments reveals AD1 thrust plane of Meliaticum over the Gemeric basement and Permian cover, in yellow. $\mathrm{f}=$ planar mesostructural elements [138]. Figure S3: AD1 thrust plane system of Meliaticum (serpentinite mélange block) over Gemericum in a gallery of the Dobšiná quarry, in red. Crosscutting steeply dipping northwest-southeast trending transpressional shear zones (D3 stage), in yellow. $\mathrm{f}=$ planar mesostructural elements [138]. Figure S4: Position of Meliaticum in the north Gemeric zone [95]. Internal structure of Meliaticum unifies different lithological blocks from the pre-D1 stage. The scheme includes a direction of thrusting (AD1, top-to-the northeast), unroofing (top-to-the southwest); more external-relates to the contact of Gemericum and Veporicum superunits (AD2), as well as conjugated northwest-southeast trending dextral shearing (AD3, Košice-Margecany shear zone) and northeast-southwest trending shearing (Trans-Gemeric shear zone). The map, as well as the detail of the Kurtavá skala Hill, show the angular discordance of northwest-dipping planar elements in allochthonous Meliatic bodies with the general Alpine structural plan in the north Gemeric zone. Figure S5: Structures of metabasites from Meliatic paleotectonic units. A,E,F from Jaklovce Unit, B-D from Bôrka Unit. Examples of the Bôrka Unit blueschists: (A) pre-metamorphic (pre-D1) layering - alternation of reddish radiolarites with N-MOR type basalts and dolerites; (B) refolded metamorphic schistosity S1 with the Gln (D1) of a blueschist layer in Tlc-Chl-Ph-Cal schists, with an axial-plane cleavage with Ttn (D2); (C) lenses of a blueschist mineral assemblage from the D1 stage with S1 defined by Gl-Ph-Grt in secondary cleavage planes, S2, with signatures of shearing and the grain size reduction (D2); (D) blueschist layer in marble with oriented Gln aggregates in D1 metamorphic schistosity S1 overgrown by Chl (D1-D2); and (E,F) microfolds of the blueschist metamorphic schistosity S1 (D1) defined by bluish Gln aggregates. Axial plane schistosity S2 (D2) with reoriented and partly recrystallised Gln. Pictures C-E at II N; B and F at X N. Figure S6: Meso- (A-E) and microstructures (F) of metasilicites from Jaklovce Unit: (A) similar folds with a southeast dipping axial plane cleavage in greenish metaradiolarite (late D2-D3 stage?); (B) distinctly schistose metasilicite. S-dipping S1 metamorphic schistosity (D1) crosscut by SE-dipping //S2 metamorphic cleavage (D2); (C-E) angular relationship between S1 metamorphic schistosity (D1) and S2 late-metamorphic cleavage (D2); brittle-ductile kink folds with S3 system (AD3?); (F) sheared metasilicate (D2?). Picture F at II N. Figure S7: Meso- (A-C) and microstructures (D-F) of marbles from Bôrka (A-E) and Jaklovce (F) paleotectonic units: (A) alternation of pale carbonates and dark schists indicate northwest dipping sedimentary bedding planes S0 parallel to superimposed S1 metamorphic schistosity (D1). Northwest steeply dipping S2 metamorphic layering (D2, visible in circle). Southwest steeply dipping cleavage S3 (AD3); (B) hematite-rich layers as indicators of refolded S0 bedding and S1 metamorphic planes (D1), crosscut by predominant northeast-dipping axial-plane metamorphic schistosity S2 (D2). A and B-Kurtavá skala Hill quarry at Jaklovce; (C) predominant S1 metamorphic schistosity of a mid-Triassic metacarbonate as olitolith in Jurassic flysch. C-E-Meliata quarry; (D) S1 metamorphic schistosity and shearing in Cal marble with fragmented Dol porphyroclasts (D1-D2); (E) coarse-grained part of the marble with Ab porpyroblasts (D1); (F) flattened nodules of siliceous metacarbonate infilled by metamorphic Wnc/Act (D1); pictures of D and F at II N, E at X N. Figure S8: Meso- (A-D) and microstructures (E-H) of calciclastic (A-B, E-F) and siliciclastic (C and H) flysch metasediments, with a Triassic radiolarite olistolith (D and G, at the Meliata locality) from the Meliata Unit; (A,B) mesoscopic intrafolial folds of metamorphic S1 planes (D1) with axial-plane cleavage S2 (D2) in calciclastic flysch in Jaklovce (D1-D2 stages); (C) tectonic contact of metaradiolarite with siliciclastic flysch in the Jaklovce mélange (late-D2-D3 stage); (D) bedding planes S0 (// S1 anchimetamorphic 
schistosity, see picture G) of a mid-Triassic radiolarite olistolith in Jurassic flysch olistostroma at the Meliata village; (E) calciclastic flysch (from outcrops A, B) with recrystallised Cal-rich layer with newly formed Ab; (F) microscopic intrafolial folds of metamorphic S1 planes (D1) with axial-plane cleavage S2 (D2) in calciclastic flysch in Jaklovce (D1-D2 stages; cf. A, B); and (G) anchimetamorphic schistosity S1//S0 (D1-D2?) in a dark red Triassic radiolarite olistolith in siliciclastic flysch metasediments; $(\mathrm{H})$ anchimetamorphic schistosity S1 (D1-D2?) in cherty siliciclastic flysch metasediments at Meliata village; Qtz-Ab-Cal pseudomorphs after radiolarians. Pictures E-H at X N.

Author Contributions: Conceptualisation, M.P. and O.N.; field investigation, M.P., P.R., O.N. and Z.N.; methodology, O.N., P.B., M.P., software O.N., P.B.; validation, M.P., P.R.; formal analysis, O.N.; resources, P.R.; data curation, O.N., P.B., M.P.; writing—original draft preparation, M.P., O.N., P.B.; writing-review and editing, O.N., M.P., P.B., Z.N.; supervision and funding, M.P., P.B.; project administration, M.P.; funding acquisition, M.P. All authors have read and agreed to the published version of the manuscript.

Funding: This research was funded by the Slovak Research and Development Agency (contracts APVV-15-0050, APVV-18-0065, APVV-19-0065) and VEGA Agency (No. 1/0151/19, No. 1/0137/20).

Acknowledgments: Constructive reviews of three reviewers are greatly appreciated. We thank R. Marshall and Sam Spitty for reviewing the English content. We would like to express our special thanks to O. Vidal for providing the MATLAB script and his help with Chl-Ph-Qtz- $\mathrm{H}_{2} \mathrm{O}$ multi-equilibria calculations.

Conflicts of Interest: The authors declare no conflict of interest. The funders had no role in the design of the study; in the collection, analyses, or interpretation of the data; in the writing of the manuscript, or in the decision to publish the results.

\section{References}

1. Platt, J.P. Exhumation of high-pressure rocks: A review of concepts and processes. Terra Nova 1993, 5, 119-133. [CrossRef]

2. Cloos, M. Lithospheric buoyancy and collisional orogenesis: Subduction of oceanic plateaus, continental margins, island arcs, spreading ridges, and seamounts. Geol. Soc. Am. Bull. 1993, 105, 715. [CrossRef]

3. Ernst, W.G. Metamorphic zonations on presumably subducted lithospheric plates from Japan, California and the Alps. Contrib. Mineral. Petrol. 1971, 34, 43-59. [CrossRef]

4. Liou, J.G.; Zhang, R.Y.; Eide, E.A.; Maruyama, S.; Ernst, W.G. Metamorphism and tectonics of high-P and ultrahigh-P belts in the Dabie-Sulu region, eastern central China. In Tectonic Evolution of Asia; Yin, A., Harrison, T.M., Eds.; Cambridge University Press: Cambridge, UK, 1996; pp. 300-343.

5. Rumble, D.; Liou, J.G.; Jahn, B.M. Continental crust subduction and UHP metamorphism. In The Crust, Treatise on Geochemistry; Rudnick, R.L., Holland, H.D., Turekian, K.K., Eds.; Elsevier: Amsterdam, The Netherlands, 2003; Volume 3, pp. 293-320.

6. Zheng, Y.-F.; Zhou, J.-B.; Wu, Y.-B.; Xie, Z. Low-Grade Metamorphic Rocks in the Dabie-Sulu Orogenic Belt: A Passive-Margin Accretionary Wedge Deformed during Continent Subduction. Int. Geol. Rev. 2005, 47, 851-871. [CrossRef]

7. López-Carmona, A.; Abati, J.; Reche, J. Petrologic modeling of chloritoid-glaucophane schists from the NW Iberian Massif. Gondwana Res. 2010, 17, 377-391. [CrossRef]

8. Kozur, H.; Mock, R. Zum Alter und zur tektonischen Stellung der Meliata-Serie des Slowakischen Karstes. Geol. Zbor. Geol. Carpath. 1973, 24, 365-374.

9. Kozur, H.; Mock, R. Erster Nachweis von Jura in der Meliata-Einheit der südlichen Westkarpaten. Geol. Paläont. Mitt. Innsbruck 1985, 13, 223-238.

10. Kozur, H. The evolution of the Meliata-Hallstatt ocean and its significance for the early evolution of the Eastern Alps and Western Carpathians. Palaeogeogr. Palaeocl. 1991, 87, 109-135. [CrossRef]

11. Mock, R.; Sýkora, M.; Aubrecht, R.; Ožvoldová, L.; Kronome, B.; Reichwalder, P.; Jablonský, J. Petrology and petrography of the Meliaticum near the Meliata and Jaklovce villages, Slovakia. Slovak Geol. Mag. 1998, 4, 223-260.

12. Faryad, S.W.; Spišiak, J.; Horváth, P.; Hovorka, D.; Dianiška, I.; Jósza, S. Petrological and geochemical features of the Meliata mafic rocks from the sutured Triassic oceanic basin, Western Carpathians. Ofioliti 2005, 30, $27-35$. 
13. Kovács, S.; Sudar, M.; Karamata, S.; Haas, J.; Peró, C.; Grădinaru, E.; Gawlick, H.-J.; Gaetani, M.; Mello, J.; Polák, M. Triassic environments in the Circum-Pannonian Region related to the initial Neotethyan rifting stage. In Variscan and Alpine terranes of the Circum-Pannonian Region; Vozár, J., Ebner, F., Vozárová, A., Haas, J., Kovács, S., Sudar, M., Bielik, M., Péró, C., Eds.; Geological Institute SAS: Bratislava, Slovakia, 2010; pp. 87-156.

14. Putiš, M.; Koppa, M.; Snárska, B.; Koller, F.; Uher, P. The blueschist-associated perovskite-andradite-bearing serpentinized harzburgite from Dobšiná (the Meliata Unit), Slovakia. J. Geosci. 2012, 57, 221-240. [CrossRef]

15. Putiš, M.; Danišík, M.; Ružička, P.; Schmiedt, I. Constraining exhumation pathway in an accretionary wedge by (U-Th)/He thermochronology—Case study on Meliatic nappes in the Western Carpathians. J. Geodyn. 2014, 81, 80-90. [CrossRef]

16. Gawlick, H.-J.; Missoni, S. Middle Triassic radiolarite pebbles in the Middle Jurassic Hallstatt Mélange of the Eastern Alps: Implications for Triassic-Jurassic geodynamic and paleogeographic reconstructions of the western Tethyan realm. Facies 2015, 61, 13. [CrossRef]

17. Gawlick, H.-J.; Missoni, S. Middle-Late Jurassic sedimentary mélange formation related to ophiolite obduction in the Alpine-Carpathian-Dinaridic Mountain Range. Gondwana Res. 2019, 74, 144-172. [CrossRef]

18. Csontos, L.; Vörös, A. Mesozoic plate tectonic reconstruction of the Carpathian region. Palaeogeogr. Palaeoclimatol. Palaeoecol. 2004, 210, 1-56. [CrossRef]

19. Golonka, J. Plate tectonic evolution of the southern margin of Eurasia in the Mesozoic and Cenozoic. Tectonophysics 2004, 381, 235-273. [CrossRef]

20. Handy, M.R.; Schmid, S.M.; Bousquet, R.; Kissling, E.; Bernoulli, D. Reconciling plate-tectonic reconstructions of Alpine Tethys with the geological-geophysical record of spreading and subduction in the Alps. Earth Sci. Rev. 2010, 102, 121-158. [CrossRef]

21. Handy, M.R.; Ustaszewski, K.; Kissling, E. Reconstructing the Alps-Carpathians-Dinarides as a key to understanding switches in subduction polarity, slab gaps and surface motion. Int. J. Earth Sci. 2015, 104, 1-26. [CrossRef]

22. Stampfli, G. The Intra-Alpine terrain: A Paleotethyan remnant in the Alpine Variscides. Eclogae Geol. Helv. 1996, 89, 13-42.

23. Stampfli, G.M.; Borel, G.D.; Marchant, R.; Mosar, J. Western Alps geological constraints on western Tethyan reconstructions. J. Virtual Explor. 2002, 8, 77-106. [CrossRef]

24. Stampfli, G.M.; Kozur, H. Europe from the Variscan to the Alpine cycles. In European Lithosphere Dynamics; Gee, D.G., Stephenson., R., Eds.; Geological Society London Memoirs: London, UK, 2006; Volume 32, pp. 57-82.

25. Lexa, J.; Bezák, V.; Elečko, M.; Eliáš, M.; Konečný, V.; Less, G.; Mandl, G.W.; Mello, J.; Pálenský, P.; Pelikán, P.; et al. Geological Map of Western Carpathians and Adjacent Areas 1:500,000; Geological Survey of Slovak Republic: Bratislava, Slovakia, 2000.

26. Berman, R.G.; Brown, T.H.; Perkins, E.H. GEOe-CALC; software for calculation and display of P-T-X phase diagrams. Am. Mineral. 1987, 7-8, 861-862.

27. Berman, R.G. Thermobarometry using multi-equilibrium calculations; a new technique, with petrological applications. Can. Mineral. 1991, 4, 833-855.

28. Powell, R.; Holland, T.J.B. An internally consistent dataset with uncertainties and correlations: 3. Applications to geobarometry, worked examples and a computer program. J. Met. Geol. 1988, 6, 173-204. [CrossRef]

29. Connolly, J.A.D. Multivariable phase diagrams; an algorithm based on generalized thermodynamics. Am. J. Sci. 1990, 290, 666-718. [CrossRef]

30. Connolly, J.A.D.; Petrini, K. An automated strategy for calculation of phase diagram sections and retrieval of rock properties as a function of physical conditions. J. Met. Geol. 2002, 20, 697-708. [CrossRef]

31. de Capitani, C.; Petrakakis, K. The computation of equilibrium assemblage diagrams with Theriak/Domino software. Am. Min. 2010, 95, 1006-1016. [CrossRef]

32. Lanari, P.; Duesterhoeft, E. Modeling Metamorphic Rocks Using Equilibrium Thermodynamics and Internally Consistent Databases: Past Achievements, Problems and Perspectives. J. Petrol. 2019, 60, 19-56. [CrossRef]

33. Holland, T.J.B.; Powell, R. An improved and extended internally consistent thermodynamic dataset for phases of petrological interest, involving a new equation of state for solids. J. Met. Geol. 2011, 29, 333-383. [CrossRef] 
34. White, R.W.; Powell, R.; Holland, T.J.B. Progress relating to calculation of partial melting equilibria for metapelites. J. Met. Geol. 2007, 25, 511-527. [CrossRef]

35. White, R.W.; Powell, R.; Holland, T.J.B.; Johnson, T.E.; Green, E.C.R. New mineral activity-composition relations for thermodynamic calculations in metapelitic systems. J. Met. Geol. 2014, 32, 261-286. [CrossRef]

36. Holland, T.J.B.; Hudson, N.F.C.; Powell, R.; Harte, B. New Thermodynamic Models and Calculated Phase Equilibria in NCFMAS for Basic and Ultrabasic Compositions through the Transition Zone into the Uppermost Lower Mantle. J. Petrol. 2013, 54, 1901-1920. [CrossRef]

37. Green, E.C.R.; White, R.W.; Diener, J.F.A.; Powell, R.; Holland, T.J.B.; Palin, R.M. Activity-composition relations for the calculation of partial melting equilibria in metabasic rocks. J. Met. Geol. 2016, 34, 845-869. [CrossRef]

38. Zhou, G.; Zhang, J.; Li, Y.; Lu, Z.; Mao, X.; Teng, X. Metamorphic Evolution and Tectonic Implications of the Granulitized Eclogites from the Luliangshan Terrane in the North Qaidam Ultrahigh Pressure Metamorphic Belt, NW China: New Constraints from Phase Equilibrium Modeling. J. Earth Sci. 2019, 30, 585-602. [CrossRef]

39. Weller, O.M.; Copley, A.; Miller, W.G.R.; Palin, R.M.; Dyck, B. The relationship between mantle potential temperature and oceanic lithosphere buoyancy. Earth Planet. Sci. Lett. 2019, 518, 86-99. [CrossRef]

40. Brown, M.; Johnson, T. Metamorphism and the evolution of subduction on Earth. Am. Mineral. 2019, 104, 1065-1082. [CrossRef]

41. Godet, A.; Guilmette, C.; Labrousse, L.; Davis, D.W.; Smit, M.A.; Cutts, J.A.; Vanier, M.; Lafrance, I.; Charette, B. Complete metamorphic cycle and long-lived anatexis in the c. 2.1 Ga Mistinibi Complex, Canada. J. Met. Geol. 2020, 38, 235-264. [CrossRef]

42. Vidal, O.; Parra, T. Exhumation paths of high-pressure metapelites obtained from local equilibria for chlorite-phengite assemblages. Geol. J. 2000, 35, 139-161. [CrossRef]

43. Vidal, O.; Andrade, V.D.E.; Lewin, E.; Munoz, M.; Parra, T.; Pascarelli, S. P-T-deformation-Fe $\mathrm{Fe}^{3+} / \mathrm{Fe}^{2+}$ mapping at the thin section scale and comparison with XANES mapping: Application to a garnet-bearing metapelite from the Sambagawa metamorphic belt (Japan). J. Metamorph. Geol. 2006, 24, 669-683. [CrossRef]

44. Pourteau, A.; Bousquet, R.; Vidal, O.; Plunder, A.; Duesterhoeft, E.; Candan, O.; Oberhänsli, R. Multistage growth of $\mathrm{Fe}-\mathrm{Mg}$-carpholite and $\mathrm{Fe}-\mathrm{Mg}$-chloritoid, from field evidence to thermodynamic modelling. Contrib. Mineral. Petrol. 2014, 168, 1090. [CrossRef]

45. Grosch, E.G.; Vidal, O.; Abu-Alam, T.; McLoughlin, N. P-T Constraints on the Metamorphic Evolution of the Paleoarchean Kromberg Type-Section, Barberton Greenstone Belt, South Africa. J. Petrol. 2012, 53, 513-545. [CrossRef]

46. Cantarero, I.; Lanari, P.; Vidal, O.; Alías, G.; Travé, A.; Baqués, V. Long-term fluid circulation in extensional faults in the central Catalan Coastal Ranges: P-T constraints from neoformed chlorite and K-white mica. Int. J. Earth Sci. 2014, 103, 165-188. [CrossRef]

47. Dubacq, B.; Vidal, O.; de Andrade, V. Dehydration of dioctahedral aluminous phyllosilicates: Thermodynamic modelling and implications for thermobarometric estimates. Contrib. Mineral. Petrol. 2010, 159, 159. [CrossRef]

48. Putiš, M.; Soták, J.; Li, Q.-L.; Ondrejka, M.; Li, X.-H.; Hu, Z.; Ling, X.; Nemec, O.; Németh, Z.; Ružička, P. Origin and Age Determination of the Neotethys Meliata Basin Ophiolite Fragments in the Late Jurassic-Early Cretaceous Accretionary Wedge Mélange (Inner Western Carpathians, Slovakia). Minerals 2019, 9, 652. [CrossRef]

49. Bezák, V.; Broska, I.; Ivanička, J.; Reichwalder, P.; Vozár, J.; Polák, M.; Havrila, M.; Mello, J.; Biely, A.; Plašienka, D.; et al. Tectonic Map of Slovak Republic 1: 500,000; Ministry of the Environment of the Slovak Republic, State Geological Institute of Dionýz Štúr: Bratislava, Slovakia, 2004.

50. Grecula, P.; Kobulský, J.; Gazdačko, L.; Németh, Z.; Hraško, L.; Novotný, L.; Maglay, J. Geological Map of the Spiš-Gemer Ore Mts. 1: 50,000; State Geological Institute of D. Štúr: Bratislava Slovakia, 2009.

51. Mello, J.; Reichwalder, P.; Vozárová, A. Bôrka Nappe: High-pressure relic from the subduction-accretion prism of the Meliata ocean (Inner Western Carpathians, Slovakia). Slovak Geol. Mag. 1998, 4, 261-274.

52. Mello, J.; Elečko, M.; Pristaš, J.; Reichwalder, P.; Snopko, L.; Vass, D.; Vozárová, A. Geological Map of the Slovenský Kras Mts., 1:50,000—Regional Geological Maps of Slovakia; Ministry of environment and State geological survey of Slovak Republic: Bratislava, Slovakia, 1996. 
53. Kozur, H.; Mock, R. New paleogeographic and tectonic interpretations in the Slovakian Carpathians and their implications for correlations with the Eastern Alps and other parts of the Western Tethys. Part II: Inner Western Carpathians. Miner. Slov. 1997, 29, 164-209.

54. Árkai, P.; Faryad, S.W.; Vidal, O.; Balogh, K. Very low-grade metamorphism of sedimentary rocks of the Meliata unit, Western Carpathians, Slovakia: Implications of phyllosilicate characteristics. Int. J. Earth Sci. 2003, 92, 68-85. [CrossRef]

55. Plašienka, D.; Méres, Š.; Ivan, P.; Sýkora, M.; Soták, J.; Lačný, A.; Aubrecht, R.; Bellová, S.; Potočný, T. Meliatic blueschists and their detritus in Cretaceous sediments: New data constraining tectonic evolution of the West Carpathians. Swiss J. Geosci. 2018, 112, 55-81. [CrossRef]

56. Leško, B.; Varga, I. Alpine elements in the West Carpathian structure and their significance. Miner. Slov. 1980, 12, 97-130.

57. Kozur, H.; Mock, R.; Ožvoldová, L. New biostratigraphic results in the Meliaticum in its type area around. Meliata village (Slovakia) and their tectonic and paleogeographic significance. Geol. Paläont. Mitt. Innsbruck 1996, 21, 89-121.

58. Kantor, J. Diabase des Südslowakischen Mesozoikums. Geol. Práce Správy 1995, 41, 77-99.

59. Mello, J.; Gaál, L. Meliata Group in the Čoltovo furrow. Geol. Práce, Správy 1984, 81, 51-62.

60. Putiš, M.; Yang, Y.-H.; Vaculovič, T.; Koppa, M.; Li, X.-H.; Uher, P. Perovskite, reaction product of a harzburgite with Jurassic - Cretaceous accretionary wedge fluids (Western Carpathians, Slovakia): Evidence from the whole-rock and mineral trace element data. Geol. Carpath. 2016, 67, 133-146. [CrossRef]

61. Koppa, M.; Koller, F.; Putiš, M. Petrology and geochemistry of a peridotite body in Central Carpathian Paleogene sediments (Sedlice, eastern Slovakia). Geol. Carpath. 2014, 65, 387-399. [CrossRef]

62. Li, X.-H.; Putiš, M.; Yang, Y.-H.; Koppa, M.; Dyda, M. Accretionary wedge harzburgite serpentinization and rodingitization constrained by perovskite $\mathrm{U} / \mathrm{Pb}$ SIMS age, trace elements and $\mathrm{Sm} / \mathrm{Nd}$ isotopes: Case study from the Western Carpathians, Slovakia. Lithos 2014, 205, 1-14. [CrossRef]

63. Faryad, S.W. Phase petrology and P-T conditions of mafic blueschists from the Meliata unit, Western Carpathians, Slovakia. J. Metamorph. Geol. 1995, 13, 701-714. [CrossRef]

64. Faryad, S.W. Exhumation of the Meliata high-pressure rock (Western Carpathians): Petrological and structural records in blueschists. Acta. Montan. Slov. 1999, 2, 137-144.

65. Mazzoli, C.; Sassi, R.; Vozárová, A. The Pressure Character of the Alpine Metamorphism in the Central and Inner Western Carpathians (Czecho-Slovakia); Vozár, J., Ed.; D. Štúr Inst. Geol.: Bratislava, Slovakia, 1992; Special Volume IGCP; pp. 109-117.

66. Faryad, S.W.; Hoinkes, G. Two contrasting mineral assemblages in the Meliata blueschists, Western Carpathians, Slovakia. Miner. Mag. 1999, 63, 489-501. [CrossRef]

67. Faryad, S.W. Petrology and phase relations of low-grade high-pressure metasediments from the Meliata Unit (West Carpathians, Slovakia). Eur.J. Mineral. 1995, 7, 57-74. [CrossRef]

68. Brown, T.H.; Berman, R.G.; Perkins, E.H. GEO-CALC, software for the calculation and display of pressure-temperature-composition phase diagram using an IBM or compatible personal computer. Computer. Geosci. 1988, 14, 279-290. [CrossRef]

69. Brown, T.H.; Berman, R.G.; Perkins, E.H. PTA-system: A Geo-Calc software package for the calculation and display of activity- temperature-pressure phase diagrams. Am. Mineral. 1989, 74, 485-487.

70. Holland, T.J.B.; Powell, R. An enlarged and updated internally consistent thermodynamic dataset with uncertainties and correlations: The system $\mathrm{K}_{2} \mathrm{O}-\mathrm{Na}_{2} \mathrm{O}-\mathrm{CaO}-\mathrm{MgO}-\mathrm{MnO}-\mathrm{FeO}_{-}-\mathrm{Fe}_{2} \mathrm{O}_{3}-\mathrm{Al}_{2} \mathrm{O}_{3}-$ $\mathrm{TiO}_{2}-\mathrm{SiO}_{2}-\mathrm{C}-\mathrm{H}_{2}-\mathrm{O}_{2}$. J. Metamorph. Geol. 1990, 8, 89-124. [CrossRef]

71. Horváth, P.; Kronome, B. Petrological and mineral-chemical variations in blueschist facies metasedimentary rocks from a single outcrop in the lower complex of the Bôrka Nappe (Meliata Unit, Western Carpathians, Slovak Republic). Cent. Eur. Geol. 2008, 51, 35-70. [CrossRef]

72. Powell, R.; Holland, T.; Worley, B. Calculating phase diagrams involving solid solutions via non-linear equations, with examples using THERMOCALC. J. Met. Geol. 1998, 577-588. [CrossRef]

73. Ivan, P.; Méres, Š.; Sýkora, M. Magnesioriebeckite in red cherts and basalts (Jaklovce Fm. of the Meliatic Unit, Western Carpathians): An indicator of initial stage of the high-pressure subduction metamorphism. Miner. Slov. 2009, 41, 419-432.

74. Brown, E.H. The Crossite Content of Ca-Amphibole as a Guide to Pressure of Metamorphism. J. Petrol. 1977, 18, 53-72. [CrossRef] 
75. Horváth, P. Metamorphic evolution of gabbroic rocks of the Bodva Valley Ophiolite Complex, NE Hungary. Geol. Carpath. 2000, 51, 121-129.

76. Kövér, S.; Fodor, L.; Judik, K.; Németh, T.; Balogh, K.; Kovács, S. Deformation history and nappe stacking in Rudabánya Hills (Inner Western Carpathians) unravelled by structural geological, metamorphic petrological and geochronological studies of Jurassic sediments. Geodin. Acta 2009, 22, 3-29. [CrossRef]

77. Mello, J.; Vozárová, A.; Vozár, J.; Hanzel, V.; Káčer, Š.; Karoli, S.; Molák, B.; Šucha, V.; Siráňová, V. Report on Structural Borehole Držkovce (DRŽ-1); Archive of D. Štúr Inst. Geol.: Bratislava, Slovakia, 1994. (In Slovak)

78. Dallmeyer, R.D.; Neubauer, F.; Putiš, M. ${ }^{40} \mathrm{Ar} /{ }^{39} \mathrm{Ar}$ mineral age controls for the Pre-Alpine and Alpine tectonic evolution of nappe complexes in the Western Carpathians. In Pre-Alpine Events in the Western Carpathians' Realm; Pitoňák, P., Spišiak, J., Eds.; Confer. Excur. Guide, Slovak Academy of Sciences: Bratislava, Slovakia, 1993; pp. 11-20.

79. Dallmeyer, R.D.; Neubauer, F.; Handler, R.; Fritz, H.; Müller, W.; Pana, D.; Putiš, M. Tectonothermal evolution of the internal Alps and Carpathians: Evidence from ${ }^{40} \mathrm{Ar} /{ }^{39} \mathrm{Ar}$ mineral and whole-rock data. Eclogae Geol. Helv. 1996, 89, 203-227.

80. Dallmeyer, R.D.; Németh, Z.; Putiš, M. Regional tectonothermal events in Gemericum and adjacent units (Western Carpathians, Slovakia): Contribution by the ${ }^{40} \mathrm{Ar} /{ }^{39} \mathrm{Ar}$ dating. Slovak Geol. Mag. 2005, 11, 155-163.

81. Maluski, H.; Rajlich, P.; Matte, P. 40Ar-39Ar dating of the Inner Carpathians Variscan basement and Alpine mylonitic overprinting. Tectonophysics 1993, 223, 313-337. [CrossRef]

82. Faryad, S.W.; Henjes-Kunst, F. Petrological and K-Ar and 40Ar-39Ar age constraints for the tectonothermal evolution of the high-pressure Meliata unit, Western Carpathians (Slovakia). Tectonophysics 1997, 280, 141-156. [CrossRef]

83. Putiš, M.; Yang, Y.H.; Koppa, M.; Dyda, M.; Šmál, P. U/Pb LA-ICP-MS age of metamorphic-metasomatic perovskite from serpentinized harzburgite in the Meliata Unit at Dobšiná, Slovakia: Indicator of fluid-rock interaction age in an accretionary wedge. Acta Geol. Slov. 2015, 7, 63-71.

84. Vozárová, A.; Konečný, P.; Šarinová, K.; Vozár, J. Ordovician and Cretaceous tectonothermal history of the Southern Gemericum Unit from microprobe monazite geochronology (Western Carpathians, Slovakia). Int. J. Earth Sci. 2014, 103, 1005-1022. [CrossRef]

85. Putiš, M.; Danišík, M.; Siman, P.; Nemec, O.; Tomek, Č.; Ružička, P. Cretaceous and Eocene tectono-thermal events determined in the Inner Western Carpathians orogenic front Infratatricum. Geol. Q. 2019, 63, 248-274. [CrossRef]

86. Putiš, M.; Frank, W.; Plašienka, D.; Siman, P.; Sulák, M.; Biroň, A. Progradation of the Alpidic Central Western Carpathians orogenic wedge related to two subductions: Constrained by 40Ar/39Ar ages of white micas. Geodin. Acta 2009, 22, 31-56. [CrossRef]

87. Milovský, R.; Plaśienka, D. pT-conditions and age of thrusting of someWest-Carpathian thin-skinned nappes. In Proceedings of the 11th Workshop on Alpine Geological Studies and 7th IFAA (Poster Session), Berichte Geol. B.-A. 99, Schladming, Austria, 9-12 September 2013; pp. 46-47.

88. Vojtko, R.; Králiková, S.; Andriessen, P.; Prokešová, R.; Minár, J.; Jeřábek, P. Geological evolution of the southwestern part of the Veporic Unit (Western Carpathians): Based on fission track and morphotectonic data. Geol. Carp. 2017, 68, 285-302. [CrossRef]

89. Vojtko, R.; Králiková, S.; Minár, J.; Fügenschuh, B. Low thermal evolution of the Southern Veporic Unit crystalline basement (Central Western Carpathians) constrained by new fission track data. In Proceedings of the 11th Workshop on Alpine Geological Studies and 7th IFAA (Poster Session), Berichte Geol. B.-A. 99, Schladming, Austria, 9-12 September 2013; pp. 96-97.

90. Plašienka, D.; Grecula, P.; Putiš, M.; Kováč, M.; Hovorka, D. Evolution and structure of the Western Carpathians: An overview. In Geological Evolution of the Western Carpathians; Grecula, P., Hovorka, D., Putiš, M., Eds.; Miner. Slov.: Bratislava, Slovakia, 1997; pp. 1-24i.

91. Schmid, S.M.; Bernoulli, D.; Fügenschuh, B.; Matenco, L.; Schefer, S.; Schuster, R.; Tischler, M.; Ustaszewski, K. The Alpine-Carpathian-Dinaridic orogenic system: Correlation and evolution of tectonic units. Swiss J. Geosci. 2008, 101, 139-183. [CrossRef]

92. Putiš, M. Tectonic styles and Late Variscan-Alpine evolution of the Tatric-Veporic crystalline basement in the Western Carpathians. Zent. Geol. Paläontologie 1991, 1, 181-204.

93. Lexa, O.; Schulmann, K.; Ježek, J. Cretaceous collision and indentation in the West Carpathians: View based on structural analysis and numerical modelling. Tectonics 2003, 22, 1066. [CrossRef] 
94. Plašienka, D. Continuity and episodicity in the early Alpine tectonic evolution of the Western Carpathians: How large-scale processes are expressed by the orogenic architecture and rock record data. Tectonics 2018, 37, 2029-2079. [CrossRef]

95. Németh, Z.; Radvanec, M.; Kobulský, J.; Gazdačko, L.; Putiš, M.; Zákršmidová, B. Allochthonous position of the Meliaticum in the North-Gemeric zone (InnerWestern Carpathians) as demonstrated by paleopiezometric data. Miner. Slov. 2012, 44, 57-64.

96. Németh, Z.; Putiš, M.; Hraško, L'. The relation of metallogeny to geodynamic processes-The natural prerequisite for the origin of mineral deposits of public importance (MDoPI): The case study in the Western Carpathians, Slovakia. Miner. Slov. 2016, 48, 119-134.

97. Locock, A.J. An Excel spreadsheet to recast analyses of garnet into end-member components, and a synopsis of the crystal chemistry of natural silicate garnets. Comput. Geosci. 2008, 34, 1769-1780. [CrossRef]

98. Locock, A.J. An Excel spreadsheet to classify chemical analyses of amphiboles following the IMA 2012 recommendations. Comput. Geosci. 2014, 62, 1-11. [CrossRef]

99. Yavuz, F.; Kumral, M.; Karakaya, N.; Karakaya, M.Ç.; Yıldırım, D.K. A Windows program for chlorite calculation and classification. Comput. Geosci. 2015, 81, 101-113. [CrossRef]

100. Green, T.H.; Hellman, P.L. Fe-Mg partitioning between coexisting garnet and phengite at high pressure, and comments on a garnet-phengite geothermometer. Lithos 1982, 15, 253-266. [CrossRef]

101. Massonne, H.-J.; Schreyer, W. Phengite geobarometry based on the limiting assemblage with K-feldspar, phlogopite, and quartz. Contrib. Mineral. Petrol. 1987, 96, 212-224. [CrossRef]

102. Connolly, J.A.D. Computation of phase equilibria by linear programming: A tool for geodynamic modeling and its application to subduction zone decarbonation. Earth Planet. Sci. Lett. 2005, 236, 524-541. [CrossRef]

103. Christie, D.M.; Carmichael, I.S.E.; Langmuir, C.H. Oxidation states of mid-ocean ridge basalt glasses. Earth Planet. Sci. Lett. 1986, 79, 397-411. [CrossRef]

104. Berry, A.J.; Danyushevsky, L.V.; St, C.; O'Neill, H.; Newville, M.; Sutton, S.R. Oxidation state of iron in komatiitic melt inclusions indicates hot Archaean mantle. Nature 2008, 455, 960-963. [CrossRef]

105. Palin, R.M.; White, R.W.; Green, E.C.R.; Diener, J.F.A.; Powell, R.; Holland, T.J.B. High-grade metamorphism and partial melting of basic and intermediate rocks. J. Metamorp. Geol. 2016, 34, 871-892. [CrossRef]

106. Schmidt, M.W.; Poli, S. Experimentally based water budgets for dehydrating slabs and consequences for arc magma generation. Earth Planet. Sci. Lett. 1998, 163, 361-379. [CrossRef]

107. Powell, R.; Holland, T.J.B. On thermobarometry. J. Metamorph. Geol. 2008, 26, 155-179. [CrossRef]

108. Cathelineau, M. Cation site occupancy in chlorites and illites as function of temperature. Clay Mineral. 1988, 23, 471-485. [CrossRef]

109. Anovitz, L.M.; Essene, E.J. Phase equilibria in the system $\mathrm{CaCO}_{3}-\mathrm{MgCO}_{3}-\mathrm{FeCO}_{3}$. J. Petrol. 1987, 2, $389-414$. [CrossRef]

110. Ridolfi, F.; Renzulli, A.; Puerini, M. Stability and chemical equilibrium of amphibole in calc-alkaline magmas: An overview, new thermobarometric formulations and application to subduction-related volcanoes. Contrib. Mineral. Petrol. 2010, 160, 45-66. [CrossRef]

111. Hawthorne, F.C.; Oberti, R.; Harlow, G.E.; Maresch, W.V.; Martin, R.F.; Schumacher, J.C.; Welch, M.D. Nomenclature of the amphibole supergroup. Am. Mineral. 2012, 97, 2031-2048. [CrossRef]

112. Leake, B.E.; Woolley, A.R.; Arps, C.E.S.; Birch, W.D.; Gilbert, M.C.; Grice, J.D.; Hawthorne, F.C.; Kato, A.; Kisch, H.J.; Krivovichev, V.G.; et al. Nomenclature of Amphiboles; Report of the Subcommittee on Amphiboles of the International Mineralogical Association Commission on New Minerals and Mineral Names. Mineral. Mag. 1997, 61, 295-310. [CrossRef]

113. Tischendorf, G.; Förster, H.-J.; Gottesmann, B.; Rieder, M. True and brittle micas: Composition and solid-solution series. Mineral. Mag. 2007, 71, 285-320. [CrossRef]

114. Guidotti, C.V.; Sassi, F.P. Petrogenetic significance of Na-K white mica mineralogy: Recent advances for metamorphic rocks. Eur. J. Mineral. 1998, 10, 815-854. [CrossRef]

115. Zane, A.; Weiss, Z. A procedure for classifying rock-forming chlorites based on microprobe data. Rend. Lincei 1998, 9, 51-56. [CrossRef]

116. Kübler, B. Les indicateurs des transformations physiques et chimiques dans la diagenèse, température et calorimétrie. In Thermobarométrie et Barométrie Géologiques; Lagache, M., Ed.; Soc. Franc. Minéral. Cristallogr.: Paris, France, 1984; pp. 489-596. 
117. Kübler, B. Evaluation quantitative du métamorphisme par la cristallinité d l'illite. Bull. Centre Rech. Pau 1968, 2, 385-397.

118. Kübler, B. La cristallinité de l'illite et les zones tout a fait superieures du métamorphisme. In Étages Tectoniques; A La Baconniere: Neuchâtel, Switzerland, 1967; pp. 105-121.

119. Guggenheim, S.; Bain, D.C.; Bergaya, F.; Brigatti, M.F.; Drits, V.A.; Eberl, D.D.; Formoso, M.L.L.; Galán, E.; Merriman, R.J.; Peacor, D.R.; et al. Report of the Association international pour l'étude des argiles (AIPEA) Nomenclature Committee for 2001: Order, disorder and crystallinity in phyllosilicates and the use of the 'crystallinity index'. Clays Clay Miner. 2002, 50, 406-409. [CrossRef]

120. Warr, L.N. A new collection of clay mineral 'Crystallinity' Index Standards and revised guidelines for the calibration of Kübler and Árkai indices. Clay Miner. 2018, 53, 339-350. [CrossRef]

121. Árkai, P.; Sassi, F.; Sassi, R. Simultaneous measurements of chlorite and illite crystallinity: A more reliable tool for monitoring low- to very low grade metamorphism in metapelites. A case study from the southern Alps (NE Italy). Eur. J. Mineral. 1995, 7, 1115-1128. [CrossRef]

122. Árkai, P. Chlorite crystallinity: An empirical approach and correlation with illite crystallinity, coal rank and mineral facies as exemplified by Palaeozoic and Mesozoic rocks of northeast Hungary. J. Metamorph. Geol. 1991, 9, 723-734. [CrossRef]

123. Verdel, C.; van der Pluijm, B.A.; Niemi, N. Variation of illite/muscovite ${ }^{40} \mathrm{Ar} /{ }^{39} \mathrm{Ar}$ age spectra during progressive low-grade metamorphism: An example from the US Cordillera. Contrib. Min. Petrol. 2012, 164, 521-536. [CrossRef]

124. Lanari, P.; Engi, M. Local Bulk Composition Effects on Metamorphic Mineral Assemblages. Rev. Mineral. Geochem. 2017, 83, 55-102. [CrossRef]

125. Tuccillo, M.E.; Essene, E.J.; van der Pluijm, B.A. Growth and retrograde zoning in garnets from high-grade, metapelites: Implications for pressure-temperature paths. Geology 1990, 18, 839-842. [CrossRef]

126. Caddick, M.J.; Konopásek, J.; Thompson, A.B. Preservation of Garnet Growth Zoning and the Duration of Prograde Metamorphism. J. Petrol. 2010, 51, 2327-2347. [CrossRef]

127. Yardley, B.W.D. An empirical study of diffusion in garnet. Am. Mineral. 1977, 62, 793-800.

128. Velde, B. Phengite micas: Synthesis, stability, and natural occurrence. Am. J. Sci. 1965, 263, 886-891. [CrossRef]

129. Velde, B. $\mathrm{Si}^{+4}$ content of natural phengites. Contrib. Mineral. Petrol. 1967, 14, 250-258. [CrossRef]

130. Massonne, H.-J.; Schreyer, W. Stability field of the high-pressure assemblage talc + phengite and two new phengite barometers. Eur. J. Mineral. 1989, 1, 391-410. [CrossRef]

131. Massonne, H.J.; Szpurka, F. The thermodynamic properties of white micas on the basis of high-pressure experiments in the systems $\mathrm{K}_{2} \mathrm{O}-\mathrm{MgO}-\mathrm{Al} 2 \mathrm{O}_{3}-\mathrm{SiO}_{2}-\mathrm{H}_{2} \mathrm{O}$ and $\mathrm{K}_{2} \mathrm{O}-\mathrm{FeO}-\mathrm{Al}_{2} \mathrm{O}_{3}-\mathrm{SiO}_{2}-\mathrm{H}_{2} \mathrm{O}$. Lithos 1997, 41, 229-250. [CrossRef]

132. Sassi, R.; Árkai, P.; Lantai, C.; Venturini, C. Location of the boundary between the metamorphic Southalpine basement and the Paleozoic sequences of the Carnic Alps: Illite "crystallinity" and vitrinite reflectance data. Schweiz. Mineral. Petrogr. Mitt. 1995, 75, 399-412.

133. Korikovsky, S.; Putiš, M. Evolution of Authigenic and Detrital K-Micas at the Boundary between Anchimetamorphism and Low-Temperature Metamorphism during the Cretaceous Tectono-Metamorphic Cycle in the Western Carpathians. Petrology 1999, 7, 382-400.

134. Sulák, M.; Kaindl, R.; Putiš, M.; Sitek, J.; Krenn, K.; Tóth, I. Chemical and spectroscopic characteristics of potassium white micas related to polystage evolution of the Central Western Carpathians orogenic wedge. Lithos 2009, 113, 709-730. [CrossRef]

135. Hunziker, J.C.; Frey, M.; Clauer, N.; Dallmeyer, R.D.; Friedrichsen, H.; Flehmig, W.; Hochstrasser, K.; Roggwiler, P.; Schwander, H. The evolution of illite to muscovite: Mineralogical and isotopic data from the Glarus Alps, Switzerland. Contrib. Mineral. Petrol. 1986, 92, 157-180. [CrossRef]

136. Livi, K.J.T.; Veblen, D.R.; Ferry, J.M.; Frey, M. Evolution of 2:1 layered silicates in low-grade metamorphosed Liassic shales of Central Switzerland. J. Metamorph. Geol. 1997, 15, 323-344. [CrossRef]

137. Árkai, P. Phyllosilicates in very low-grade metamorphism: Transformation to micas. Rev. Mineral. Geochem. 2002, 46, 463-478. [CrossRef] 
138. Németh, Z.; Radvanec, M. Advanced Interpretation of Geological Setting and Tectogenesis in the Area of Delava-Babiná-Ostrá, Dobšiná and Jaklovce (Spiš-Gemer Ore Mts., W. Carpathians, Slovakia)_Final Report; State Geological Institute of D. Stur: Bratislava, Slovakia, 2013; pp. 91-143.

Publisher's Note: MDPI stays neutral with regard to jurisdictional claims in published maps and institutional affiliations.

(C) 2020 by the authors. Licensee MDPI, Basel, Switzerland. This article is an open access article distributed under the terms and conditions of the Creative Commons Attribution (CC BY) license (http://creativecommons.org/licenses/by/4.0/). 